\title{
Summary Of Wells Validated During Fiscal Years 1991 To 1992
}

\author{
by
}

Brad F. Lyles

June 1993 
This report was prepared as an account of work sponsored by the United States Government. Neither the United States nor the United States Department of Energy, nor any of their employees, makes any warranty, express or implied, or assumes any legal liability or responsibility for the accuracy, completeness or usefulness of any information, apparatus, product or process disclosed, or represents that its use would not infringe privately owned rights. Reference herein to any specific commercial product, process, or service by trade name, mark, manufacturer, or otherwise, does not necessarily constitute or imply its endorsement, recommendation, or favoring by the United States Government or any agency thereof. The views and opinions of authors expressed herein do not necessarily state or reflect those of the United States Government or any agency thereof.

This report has been reproduced directly from the best available copy.

Available to DOE and DOE contractors from the Office of Scientific and Technical Information, P.O. Box 62, Oak Ridge, TN 37831; prices available from (615) 576-8401.

Available to the public from the National Technical Information Serv, U.S. Department of Commerce, 5285 Port Royal Rd., Springfield, VA 22161. 


\title{
Summary Of Wells Validated During FisCal Years 1991 To 1992
}

\author{
by \\ Brad F. Lyles 1 \\ Water Resources Center \\ Desert Research Institute \\ University and Community College System of Nevada
}

Publication \#45107

prepared for

Nevada Operations Office

U.S. Department of Energy

Las Vegas, Nevada

June 1993

${ }^{1}$ Assistant Research Hydrogeologist

The work upon which this report is based was supported by the U.S. Department of Energy under Contract \#DE-AC08-90NV10845. 


\section{CONTENTS}

ABSTRACT $\ldots \ldots \ldots \ldots \ldots \ldots \ldots \ldots \ldots \ldots \ldots \ldots \ldots \ldots \ldots \ldots$

INTRODUCTION $\ldots \ldots \ldots \ldots \ldots \ldots \ldots \ldots \ldots \ldots \ldots \ldots \ldots \ldots \ldots \ldots$

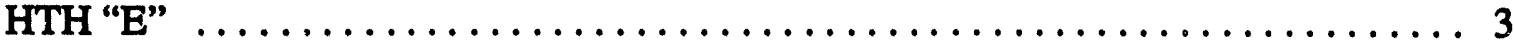

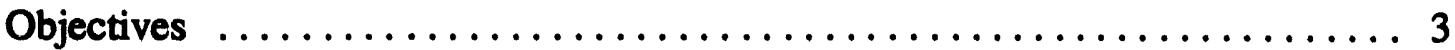

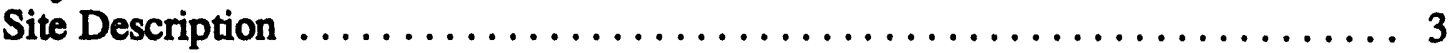

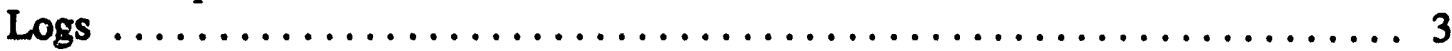

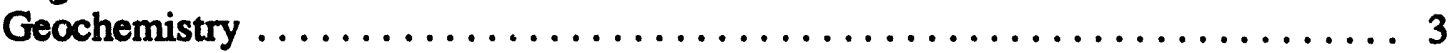

Discussion and Conclusions $\ldots \ldots \ldots \ldots \ldots \ldots \ldots \ldots \ldots \ldots \ldots \ldots$

Recommendations $\ldots \ldots \ldots \ldots \ldots \ldots \ldots \ldots \ldots \ldots \ldots \ldots \ldots \ldots \ldots$

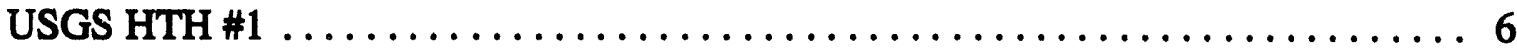

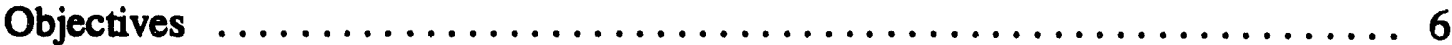

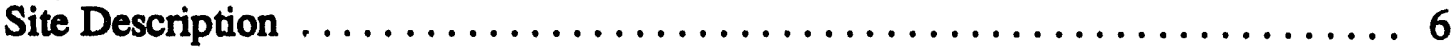

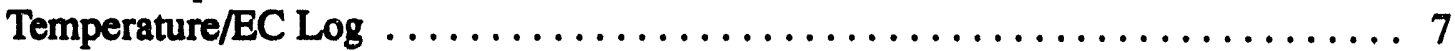

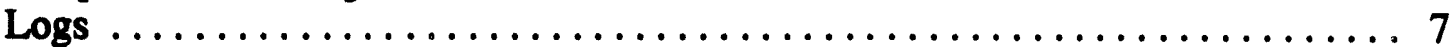

Thermal Flowmeter Survey $\ldots \ldots \ldots \ldots \ldots \ldots \ldots \ldots \ldots \ldots \ldots \ldots \ldots \ldots$

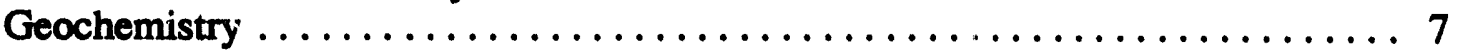

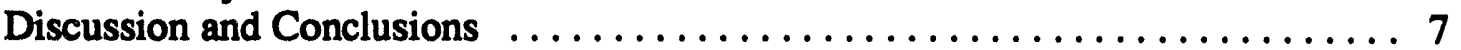

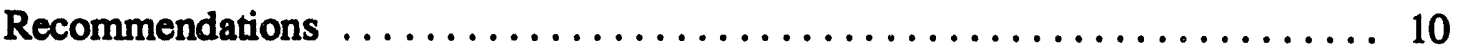

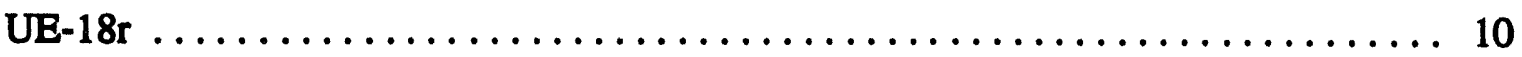

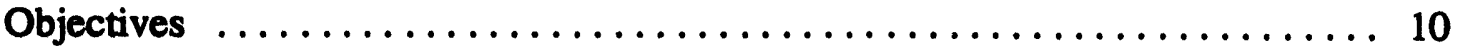

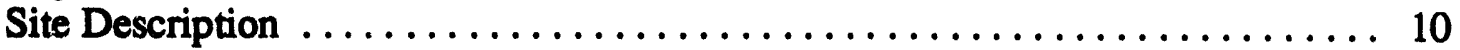

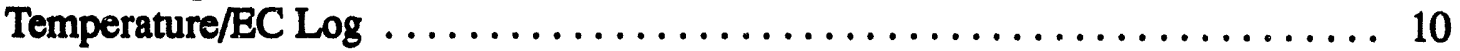

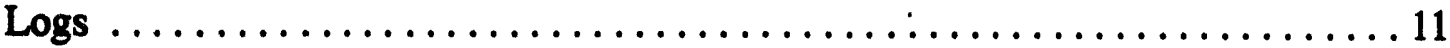

Thermal Flowmeter Survey $\ldots \ldots \ldots \ldots \ldots \ldots \ldots \ldots \ldots \ldots \ldots \ldots \ldots \ldots$

Geochemistry ..................................... 11

Discussion and Conclusions $\ldots \ldots \ldots \ldots \ldots \ldots \ldots \ldots \ldots \ldots \ldots \ldots \ldots$

Recommendations $\ldots \ldots \ldots \ldots \ldots \ldots \ldots \ldots \ldots \ldots \ldots \ldots \ldots \ldots \ldots$

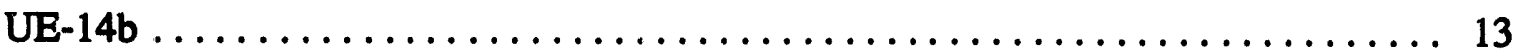

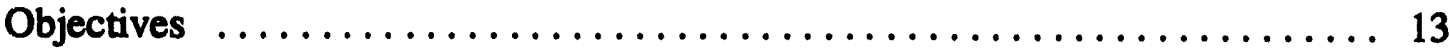

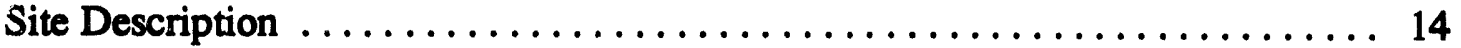

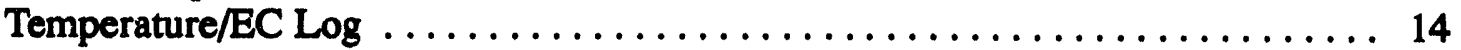

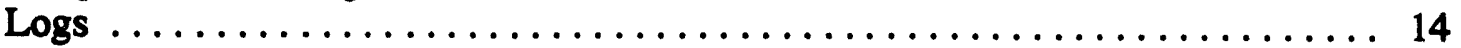

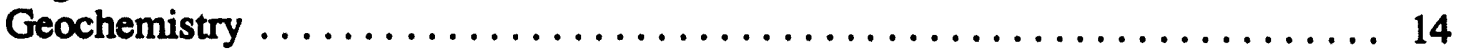

Discussion and Conclusions $\ldots \ldots \ldots \ldots \ldots \ldots \ldots \ldots \ldots \ldots \ldots \ldots \ldots$

Recommendations .............................. 17

USGS TEST WELL B Ex. $\ldots \ldots \ldots \ldots \ldots \ldots \ldots \ldots \ldots \ldots \ldots \ldots \ldots \ldots$

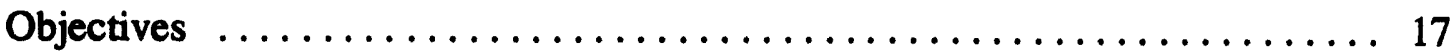

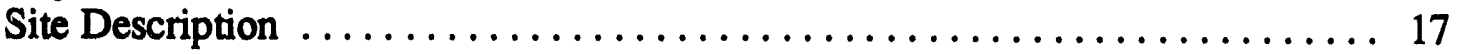

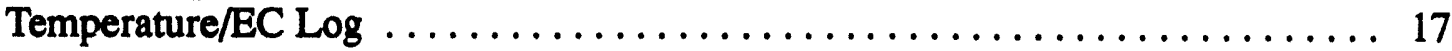

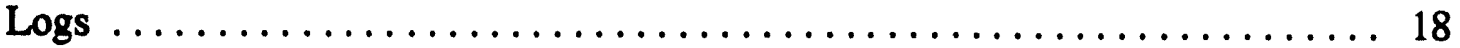

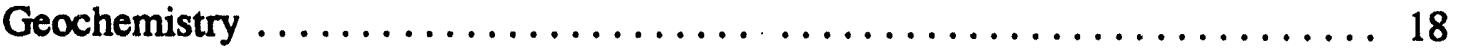

Discussion and Conclusions $\ldots \ldots \ldots \ldots \ldots \ldots \ldots \ldots \ldots \ldots \ldots \ldots \ldots \ldots$

Recommendations .............................. 18 


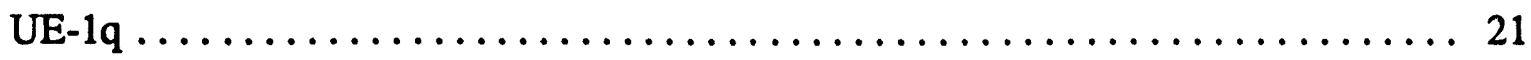

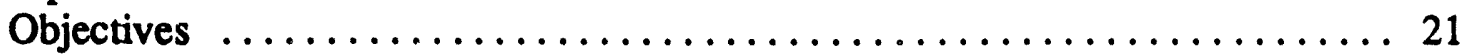

Site Description $\ldots \ldots \ldots \ldots \ldots \ldots \ldots \ldots \ldots \ldots \ldots \ldots \ldots \ldots \ldots \ldots \ldots \ldots \ldots, 21$

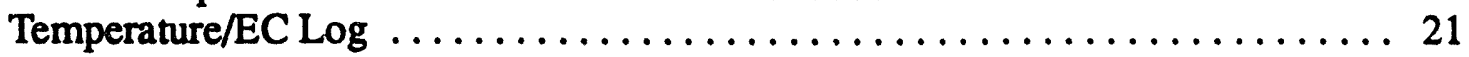

Logs $\ldots \ldots \ldots \ldots \ldots \ldots \ldots \ldots \ldots \ldots \ldots \ldots \ldots \ldots \ldots \ldots \ldots \ldots \ldots \ldots \ldots \ldots \ldots, 22$

Thermal Flowmeter Survey $\ldots \ldots \ldots \ldots \ldots \ldots \ldots \ldots \ldots \ldots \ldots \ldots \ldots, 22$

Geochemistry $\ldots \ldots \ldots \ldots \ldots \ldots \ldots \ldots \ldots \ldots \ldots \ldots \ldots \ldots \ldots \ldots \ldots \ldots, 22$

Discussion and Conclusions $\ldots \ldots \ldots \ldots \ldots \ldots \ldots \ldots \ldots \ldots \ldots \ldots, 22$

Recommendations $\ldots \ldots \ldots \ldots \ldots \ldots \ldots \ldots \ldots \ldots \ldots \ldots \ldots \ldots \ldots \ldots \ldots \ldots \ldots, 24$

UE-5n ....................................... 24

Objectives $\ldots \ldots \ldots \ldots \ldots \ldots \ldots \ldots \ldots \ldots \ldots \ldots \ldots \ldots \ldots \ldots \ldots, 24$

Site Description $\ldots \ldots \ldots \ldots \ldots \ldots \ldots \ldots \ldots \ldots \ldots \ldots \ldots \ldots, 24$

Temperature/EC Log $\ldots \ldots \ldots \ldots \ldots \ldots \ldots \ldots \ldots \ldots \ldots \ldots \ldots \ldots \ldots, 25$

Logs $\ldots \ldots \ldots \ldots \ldots \ldots \ldots \ldots \ldots \ldots \ldots \ldots \ldots \ldots \ldots \ldots \ldots \ldots \ldots \ldots \ldots \ldots, 25$

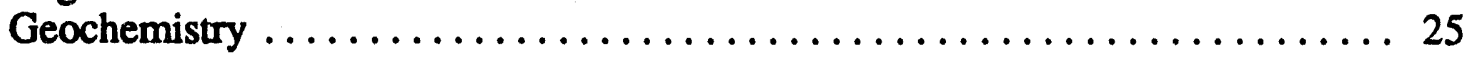

Discussion and Conclusions $\ldots \ldots \ldots \ldots \ldots \ldots \ldots \ldots \ldots \ldots \ldots \ldots, 25$

Recommendations $\ldots \ldots \ldots \ldots \ldots \ldots \ldots \ldots \ldots \ldots \ldots \ldots \ldots \ldots \ldots \ldots \ldots \ldots, 25$

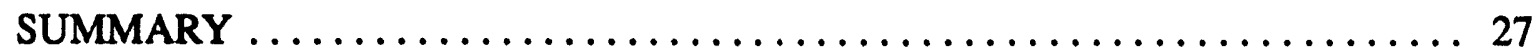

ACKNOWLEDGMENTS $\ldots \ldots \ldots \ldots \ldots \ldots \ldots \ldots \ldots \ldots \ldots \ldots \ldots \ldots \ldots$

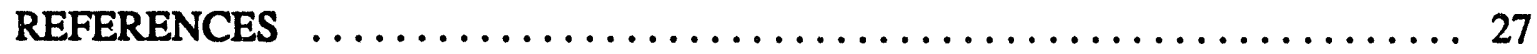

\section{APPENDICES}

A: Preliminary Data from the U.S. Geological Survey's Investigation of Well UE-18r from June 15, 1990

B: Temperature and EC Logs for Well UE-14b, Well UE-18r, Well USGS HTH \#1, Well UE-1q, Well USGS Test Well B Ex., and Well UE-5n .... 31 


\section{FIGURES}

1. Location Map of Wells Studied. $\ldots \ldots \ldots \ldots \ldots \ldots \ldots \ldots \ldots \ldots \ldots \ldots$

2. Generalized Well Completion Schematic for Well HTH "E". .......... 4

3. Generalized Well Completion Schematic and Temperature/EC Log for Well USGS HTH $\# 1 . \ldots \ldots \ldots \ldots \ldots \ldots \ldots \ldots \ldots \ldots \ldots \ldots, \ldots$

4. Generalized Well Completion Schematic and Temperature/EC Log for Well UE-18r. ..................................... 12

5. Generalized Well Completion Schematic and Temperature/EC Log for Well UE-14b. ....................................... 15

6a. Generalized Well Completion Schematic and Temperature/EC Log for Well USGS Test Well B Ex. ............................ 19

6b. Detailed View of Temperature/EC Log and Well Schematic for Well USGS Test Well B Ex.

7. Generalized Well Completion Schematic and Temperature/EC Log for Well UE-1q. ..................................... 23

8. Generalized Well Completion Schematic and Temperature/EC Log for Well UE-5n.

\section{TABLES}

1. Wells Logged During FY 1991 and FY $1992 . \ldots \ldots \ldots \ldots \ldots \ldots \ldots$

2. Geochemistry of Well HTH "E". ........................ 5

3. Geochemistry of Well USGS HTH \#1,................... 9

4. Geochemistry of Well UE-18r. ............................ 11

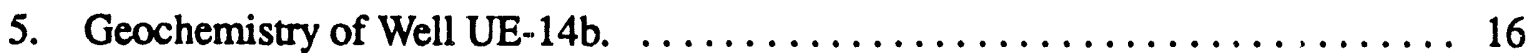

6. Geochemistry of Well USGS Test Well B Ex. $\ldots \ldots \ldots \ldots \ldots \ldots \ldots \ldots 18$

7. Geochemistry of Well UE-1q. $\ldots \ldots \ldots \ldots \ldots \ldots \ldots \ldots \ldots \ldots \ldots \ldots \ldots \ldots$ 


\begin{abstract}
The Well Validation Project was initiated in fiscal year 1990, with the intended purpose to evaluate wells on the Nevada Test Site. During fiscal years 1991 and 1992, a temperature/ electrical conductivity logging tool was redesigned and a thermal-pulse flowmeter logging tool was developed. Seven wells were evaluated during this time period: USGS HTH \#1, UE-18r, UE-14b, HTH "E", USGS Test Well B Ex., UE-1q, and UE-5n. The validation techniques used at each site varied depending on the site-specific objectives.

Thermal-pulse flowmeter surveys were carried out in several of the wells with limited success. The thermal-pulse flowmeter was designed for boreholes 2 to 6 inches in diameter; most wells at the Nevada Test Site are generally much larger in diameter, 10 to 24 inches. Therefore, the thermal-pulse flowmeter was outfitted with an inflatable rubber packer, which constricts borehole flow through the thermal-pulse flowmeter, increasing the resolution. The thermal-pulse flowmeter can be outfitted with various-sized packers depending on the borehole diameter to be evaluated; these packers are commercially available. The packers are inflated with borehole fluid via a small submersible pump which was designed, built, and tested as part of this study.
\end{abstract}




\section{INTRODUCTION}

The Well Validation Project was initiated in fiscal year (FY) 1990. The primary objectives of the project were to evaluate the condition of open boreholes at the Nevada Test Site (NTS), to develop techniques and equipment that could be used to measure hydrologic parameters such as inflow/outflow zones, vertical water movement, water level and chemical variability within boreholes, and to make recommendations related to wells monitored as part of the Department of Energy's (DOE) Long-Term Hydrologic Monitoring Program (LTHMY) when appropriate.

During FY 1990, four wells were evaluated by the Desert Research Institute (DRI) and the U.S. Geological Survey (USGS) (Lyles et al., 1991): USGS HTH \#1; UE-18r; UE-6e; and USGS HTH \#3. During the testing of these wells, equipment and techniques were developed to measure the hydrologic characteristics of the wells; these techniques and equipment were refined and new equipment was developed during FY 1991 and FY 1992.

Seven wells were evaluated in FY 1991 and FY 1992 (Figure 1; Table 1). Each well is discussed in separate sections of this report; each section includes site-specific objectives, a brief description of the completion history of the well, a listing of the data collected during this study, a discussion of our findings, and recommendations for future work and/or if the well should be included in the LTHMP as appropriate. Logs collected during this study are included in Appendix B of this report (the logs are in units of feet for comparison with other logs that may be available for each site and are scaled in 1-inch, 2-inch and 5-inch, depending on the level of detail needed to properly interpret the data; NOTE: a 1-inch log represents 100 feet of depth per inch of $\log$ ). All logged data are archived on magnetic media and are available upon request. Well names are consistent with the Raytheon Services Nevada (RSN) Nevada Test Site Drilling and Mining Summary (red book).

During FY 1991 and 1992, a thermal-pulse flowmeter (TFM) was developed. The TFM can be used to measure extremely low vertical flow in boreholes and wells to detect inflow and outflow zones. The TFM was patterned after the USGS model used during the FY 1990 study

TABLE 1. WELLS LOGGED DURING FY 1991 AND FY 1992.

\begin{tabular}{lcccc}
\hline \multicolumn{1}{c}{ Well Name } & $\begin{array}{c}\text { Date } \\
\text { Measured }\end{array}$ & $\begin{array}{c}\text { Water Depth } \\
\text { Jelow Land (m) }\end{array}$ & $\begin{array}{c}\text { Temperature/EC } \\
\text { Log Interval (m) }\end{array}$ & $\begin{array}{c}\text { Geochemical } \\
\text { Sample }\end{array}$ \\
\hline HTH “E" & $4 / 23 / 91$ & 538.4 & - & 1 \\
USGS HTH \#1 & $7 / 10 / 91$ & - & - & 5 \\
& $8 / 20 / 91$ & 446.5 & $446.5-1,129.2$ & - \\
UE-18r & $7 / 12 / 91$ & 417.6 & $417.6-1,203.6$ & 5 \\
UE-14b & $7 / 24 / 91$ & - & - & 2 \\
& $8 / 21 / 91$ & 508.0 & $509.6-1,097.8$ & 2 \\
USGS Test Well B Ex. & $8 / 19 / 91$ & 458.3 & $458.4-504.7$ & 1 \\
UE-1q & $8 / 20 / 91$ & 473.3 & $473.3-493.1$ & 1 \\
& $4 / 30 / 92$ & 473.4 & $473.6-695.8$ & - \\
UE-5n & $7 / 23 / 92$ & 214.5 & $215.8-361.2$ & - \\
\hline
\end{tabular}




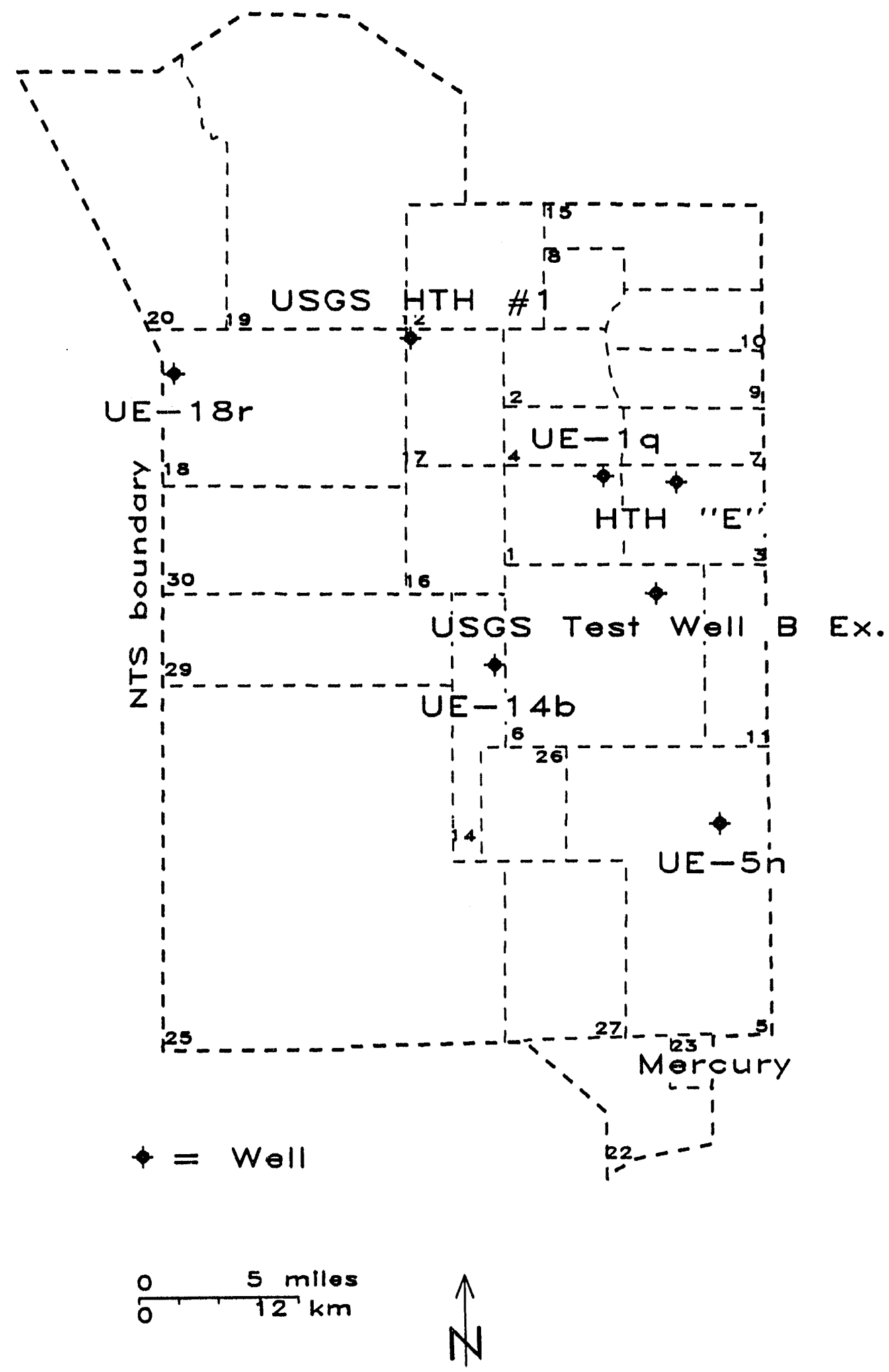

Figure 1. Location Map of Wells Studied. 
and was built based on USGS specifications (Hess, 1990). During the development of our TFM, Al Hess (the design engineer of the TFM for the USGS) was conta;ted several times for technical assistance. Field testing of the instrument was carried out at wells USGS HTH \#1, UE-1q, UE-5n and Faultless HTH-1, with limited success due to the large diameters of the boreholes encountered. Therefore, during the latter part of FY 1992, the TFM was outfitted with a pump and inflatable packer to constrict borehole flow through the TFM, thereby increasing the resolution of the tool by nearly an order of magnitude. Laboratory calibrations demonstrated that the TFM is able to detect flow rates as low as 0.08 liter per minute.

\section{HTH "E"}

\section{Objectives}

Well HTH "E" was drilled as an exploration hole and was listed as destroyed in 1962. The close proximity of this well to major underground nuclear testing areas made it a hole of opportunity to gain valuable information about fluid level and water quality. The primary objectives of this study were to evaluate the current status of the well, evaluate chemical variations within the well, and collect a fluid sample.

\section{Site Description}

HTH "E" is located near Orange Blossom Road in central Area 3 of the NTS (Figure 1) (Nevada State Coordinates: 839,989 North (ft), 696,601 East (ft)). This well was drilled as part of the USGS exploratory well program in 1962, to a total depth of $798.5 \mathrm{~m}$ (RSN, 1991) (Figure 2). The well was drilled to $600 \mathrm{~m}$ in two stages, and $30.5-\mathrm{cm}$-inside-diameter (ID) casing was installed from land surface to $177 \mathrm{~m}$ and $25.4-\mathrm{cm}-\mathrm{ID}$ casing was installed from 177 to $600 \mathrm{~m}$. The 25.4-cm-ID casing was mill-slotted from 549 to $555 \mathrm{~m}$ and from 579 to $585 \mathrm{~m}$. While drilling the well, three drill collars and a bit twisted off and were not retrievable; therefore, a side-track was drilled through the 25.4-cm-ID casing and a 15.6-cm-diameter hole was drilled to a total depth of $798.5 \mathrm{~m}$. The well was completed with $6.2-\mathrm{cm}-\mathrm{ID}$ tubing from land surface to $795.5 \mathrm{~m}$, which was jet perforated from 768 to $797 \mathrm{~m}$. The upper screened intervals are completed in volcanic tuff and the bottom screen is completed in carbonate rocks. Approximately 18 months after the well was completed, the USGS noted that the casing had collapsed.

During this study, data were collected from the well on July 23, 1991. A fluid level of $538.4 \mathrm{~m}$ below land surface was measured with a wire-line fluid-level indicator and water samples were collected from $550 \mathrm{~m}$ with a one-liter discrete sampler. The total depth of the well was 551.7 m on July 23, 1991.

\section{Logs}

A temperature/electrical conductivity (EC) log could not be measured due to an equipment malfunction; therefore, only a fluid level could be determined.

\section{Geochemistry}

A water sample was collected at $550 \mathrm{~m}$ below land surface. The sample was analyzed for selected ions and isotopes (Table 2). The water is characterized as a sodium-calcium 


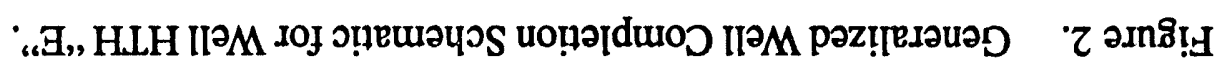

$\exists-H \perp H$
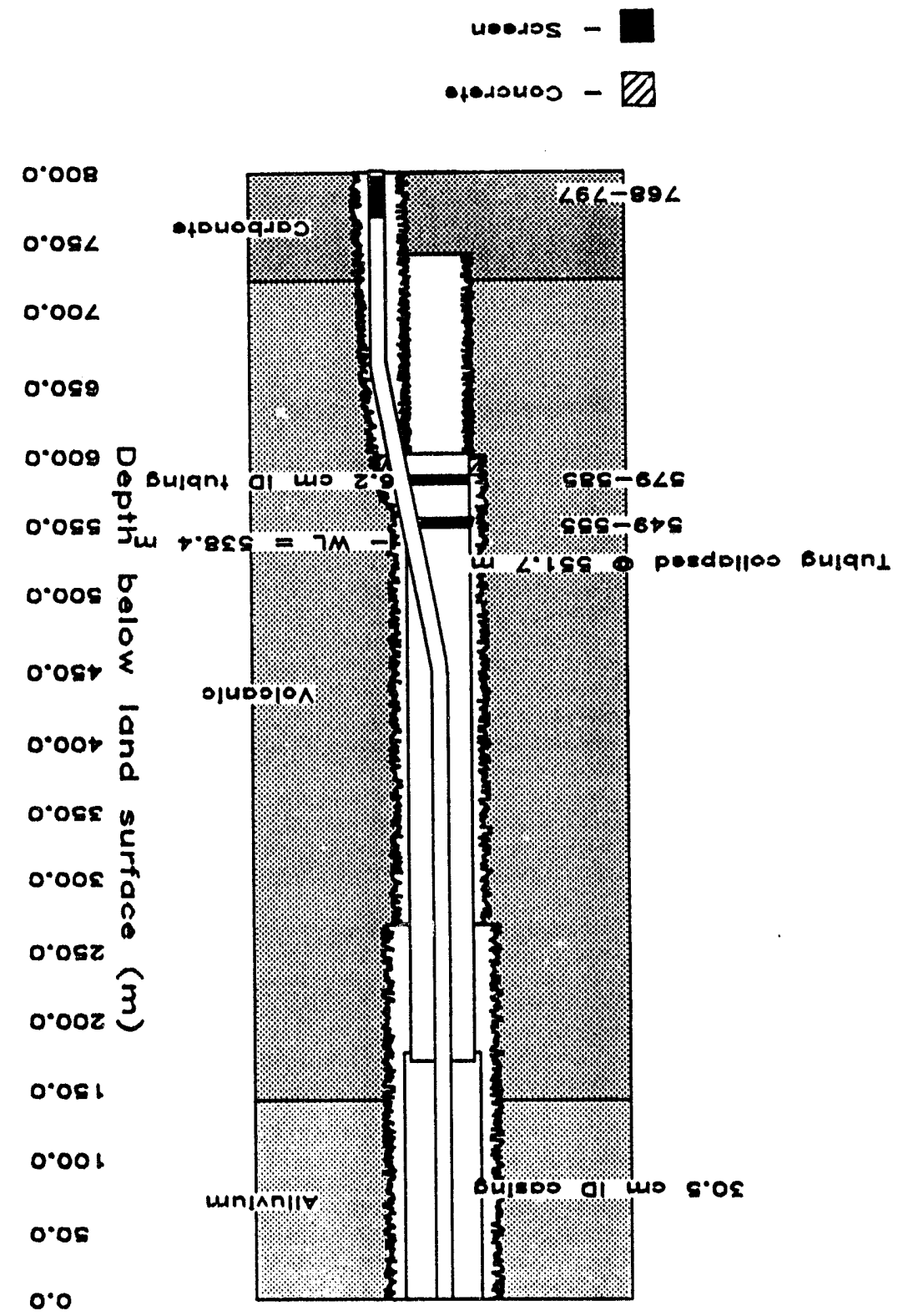
TABLE 2. GEOCHEMISTRY OF WELL HTH "E".

\begin{tabular}{lclc}
\hline Depth $(\mathrm{m})$ & 550 & $\mathrm{Cl}(\mathrm{mg} / \mathrm{l})$ & 8.2 \\
Date $(\mathrm{m} / \mathrm{d} / \mathrm{y})$ & $4 / 23 / 91$ & $\mathrm{SO}_{4}(\mathrm{mg} / \mathrm{l})$ & 1.10 \\
$\mathrm{pH}(\mathrm{units})$ & 8.45 & $\mathrm{HCO}_{3}(\mathrm{mg} / \mathrm{l})$ & 58.0 \\
$\mathrm{EC}(\mu \mathrm{S} / \mathrm{cm})$ & 130 & $\mathrm{CO}_{3}(\mathrm{mg} / \mathrm{l})$ & 1.8 \\
$\mathrm{Ca}(\mathrm{mg} / \mathrm{l})$ & 10.2 & $\mathrm{NO}_{3}(\mathrm{mg} / \mathrm{l})$ & 0.13 \\
$\mathrm{Mg}(\mathrm{mg} / \mathrm{l})$ & 0.63 & $\mathrm{SiO}_{2}(\mathrm{mg} / \mathrm{l})$ & 2.5 \\
$\mathrm{Na}(\mathrm{mg} / \mathrm{l})$ & 16.5 & $\mathrm{Tritium}(\mathrm{pCi} / \mathrm{l})$ & $<10$ \\
$\mathrm{~K}(\mathrm{mg} / \mathrm{l})$ & 1.71 & & \\
\hline
\end{tabular}

bicarbonate type water, which more closely resembles water derived from carbonate rock aquifers than from volcanic or alluvial rock aquifers sampled in the area (Chapman and Lyles, 1993). However, the EC is slightly less than what is expected from carbonate rock aquifers.

\section{Discussion and Conclusions}

Upon initial examination of the well, it was noted that the well appeared to be completely sealed with two steel couplings welded to a steel plate, which was in turn welded to the casing; each coupling was sealed with threaded caps. When the smaller of the two caps $(6.2-\mathrm{cm}-\mathrm{ID}$ tubing) was removed, no venting was noted; however, when the larger cap (4-inch NPT open to the well casing) was removed, air came out of the well for approximately five minutes. The fact that the well vented and the tubing did not vent suggests that the two are separate piezometers. An open-tube bailer was run inside the 6.2-cm-diameter tubing to collect a preliminary fluid check and as an alignment test (the bailer mandrel dimensions were 5.56-cm-outside-diameter (OD) by $186.7 \mathrm{~cm}$ long); the open-tube bailer stopped at $539 \mathrm{~m}$. A smaller sinker-bar was lowered to $551.7 \mathrm{~m}$ ( $4.5-\mathrm{cm}-\mathrm{OD}$ by $91.4 \mathrm{~cm}$ long). A fluid level of 538.4 $\mathrm{m}$ below land surface was measured with a wire-line fluid-level indicator and water samples were collected from $550 \mathrm{~m}$ with a one-liter discrete sampler.

The current fluid level in the tubing is $15.4 \mathrm{~m}$ lower than the most recent measurement (April 1962) nearly 30 years ago. However, the 1962 measurement was presumably made when there was still hydraulic communication between the carbonate and volcanic aquifers, based on the hole history data. The geochemical data and well venting observations during this study suggest that the currently measured fluid level may be the fluid level in the carbonate aquifer and in the lower volcanic aquifer.

\section{Recommendations}

The well is listed as destroyed (RSN, 1991) and has not been entered since 1962, prior to this study. The following recommendations are made with this in mind.

- Run a temperature/EC log with a small-diameter logging tool in the zone below the collapsed casing.

- Measure the hydraulic connection between the casing and the tubing. Install a wire-line pressure transducer in the $6.2-\mathrm{cm}$-ID tubing below the water table, then open the 
threaded cap into the 25.4-cm-ID well casing and monitor any pressure responses in the carbonate aquifer. The transducer may remain in the tubing for several days to ensure that all data have been collected. Use these data to approximate the hydraulic properties between the volcanic and carbonate aquifers. These data would be useful if this well is to be added to a monitoring well network.

\section{USGS HTH \#1}

\section{Objectives}

Above-background tritium activity was detected in two samples collected by DRI personnel in 1987: 90 and $48 \mathrm{pCi} / 1$ from 119 and $725 \mathrm{~m}$ below land surface, respectively. These tritium activities, although well below drinking water standards, were of interest to DOE. Therefore, a detailed sampling protocol was developed and water samples were collected from several discrete depths to characterize geochemical variations. To further evaluate the potential sources of tritium, a temperature/EC $\log$ was run to identify potential inflow/outflow zones in the well, and USGS personnel ran a TFM survey to quantify vertical flow within the well. Geochemically, the well is nearly uniform throughout the water column. One water sample above the top screened interval showed elevated tritium activities (above background $>50$ pCi/1); the tritium activities of water samples below the top screen were nearly uniform, 10 to $12 \mathrm{pCi} / 1$, well below brckground. The primary objectives of this study were to identify zones of elevated tritium activity and determine how the tritium is entering the well.

\section{Site Description}

Well USGS HTH \#1 is located at the northwest corner of Area 17 of the NTS (Figure 1) (Nevada State Coordinates: 876,855 North (ft), 629,310 East ( $\mathrm{ft}$ )). This well was drilled as an exploratory hole to a depth of $1,282 \mathrm{~m}$ in 1962 . The upper $492 \mathrm{~m}$ of the well was completed with $30-\mathrm{cm}-\mathrm{ID}$ casing. The bottom of the well was completed with $20-\mathrm{cm}-\mathrm{ID}$ casing from 475 to $1,131 \mathrm{~m}$, which was gun perforated in five zones ( 740 to 722,692 to 680,658 to 640,625 to 619 , and 594 to $582 \mathrm{~m}$ ). There are no gravel or annular seals between zones, and the bottom $154 \mathrm{~m}$ of the borehole was isolated from the well with a concrete bridge-plug at $1,128 \mathrm{~m}$.

Well USGS HTH \#1 was visited by DRI and USGS personnel on June 12, 1990, as part of the FY 1990 Well Validation Project. The USGS ran a temperature log and a TFM survey, and determined that water was flowing downward from the upper perforations and was leaving through the lowest perforation (Morin, 1990b). Only preliminary TFM data have been received from the USGS to date. Seven water samples were collected by DRI on September 24-26, 1990, to evaluate the geochemistry associated with each perforated interval in the well (Lyles et al., 1991). During the 1990 sampling, elevated tritium was detected at $472 \mathrm{~m}(76 \pm 9 \mathrm{pCi} / 1)$.

During this study, data were collected from the well on July 10, 1991 by DRI personnel. Water samples were collected from five zones $(418.3,507.5,762.0,914.4$, and $1,122.3 \mathrm{~m})$ to further understand the possible source of the elevated tritium previously observed, as recommended by Lyles et al. (1991). A temperature/EC log was measured on August 20, 1991. 
Temperature/EC Log

- Log Date: August 20, 1991

- Operators: Brad F. Lyles/Sam Hokett/David Gillespie

- Temperature/EC Log Summary

\begin{tabular}{|l|c|c|c|}
\hline & Depth $(\mathrm{m})$ & Temperature $(\mathrm{C})$ & $\mathrm{EC}(\mu \mathrm{S} / \mathrm{cm} @ 25(\mathrm{C}))$ \\
\hline minimum & 446.5 & 20.7 & 153.7 \\
\hline maximum & $1,129.2$ & 30.1 & 197.9 \\
\hline range & 682.7 & 9.4 & 44.2 \\
\hline
\end{tabular}

- Fluid Level: $446.5 \mathrm{~m}$

- Total Depth: $1,129.2 \mathrm{~m}$

\section{Logs}

The temperature/EC $\log$ is shown adjacent to the well schematic in Figure 3, and a 1-inch per 100 foot field $\log$ is included in Appendix B of this report. In the field log, English units are used for depth for comparison with other logs run in the well.

\section{Thermal Flowmeter Survey}

A TFM survey was conducted by the USGS in July 1990; only preliminary data are available to date. This survey suggested that groundwater is flowing into the well from the top of the 20-cm-diameter casing and from the upper four perforated zories, and is flowing out of the well at the lowest perforated zone (Morin, 1990b). No data are available on the flow velocities or flow volumes observed during the USGS study.

\section{Geochemistry}

Water samples were collected from five discrete depths $(418.3,507.5,762.0,914.4$, and $?, 212.3 \mathrm{~m}$ ) during this study and from seven depths during the 1990 study (Lyles et al., 1991). Two of the samples from the 1990 study are within the same depth range as the data collected here and are included in Table 3 for reference. The samples were analyzed for selected ions and isotopes. The water is characterized as a sodium-potassium bicarbonate type water, indicative of water derived from volcanic rock aquifers. Water samples from above the top screen have slightly higher EC than the water samples from the top screened interval. The highest tritium activity $(76 \mathrm{pCi} / \mathrm{l})$ was also found in the region above the top screen.

\section{Discussion and Conclusions}

The temperature/EC measurements were similar to previous measurements (Lyles et al., 1991). The temperature generally increased with increasing depth, while the EC remained relatively constant from the upper screened interval to the bottom of the hole. The temperature gradient was relatively constant from the water table $(447 \mathrm{~m})$ to the top screen $(582 \mathrm{~m})\left(1.5^{\circ} \mathrm{C}\right.$ per $100 \mathrm{~m}$ ), remained relatively constant from the top screen to the top of the fourth screen (from 


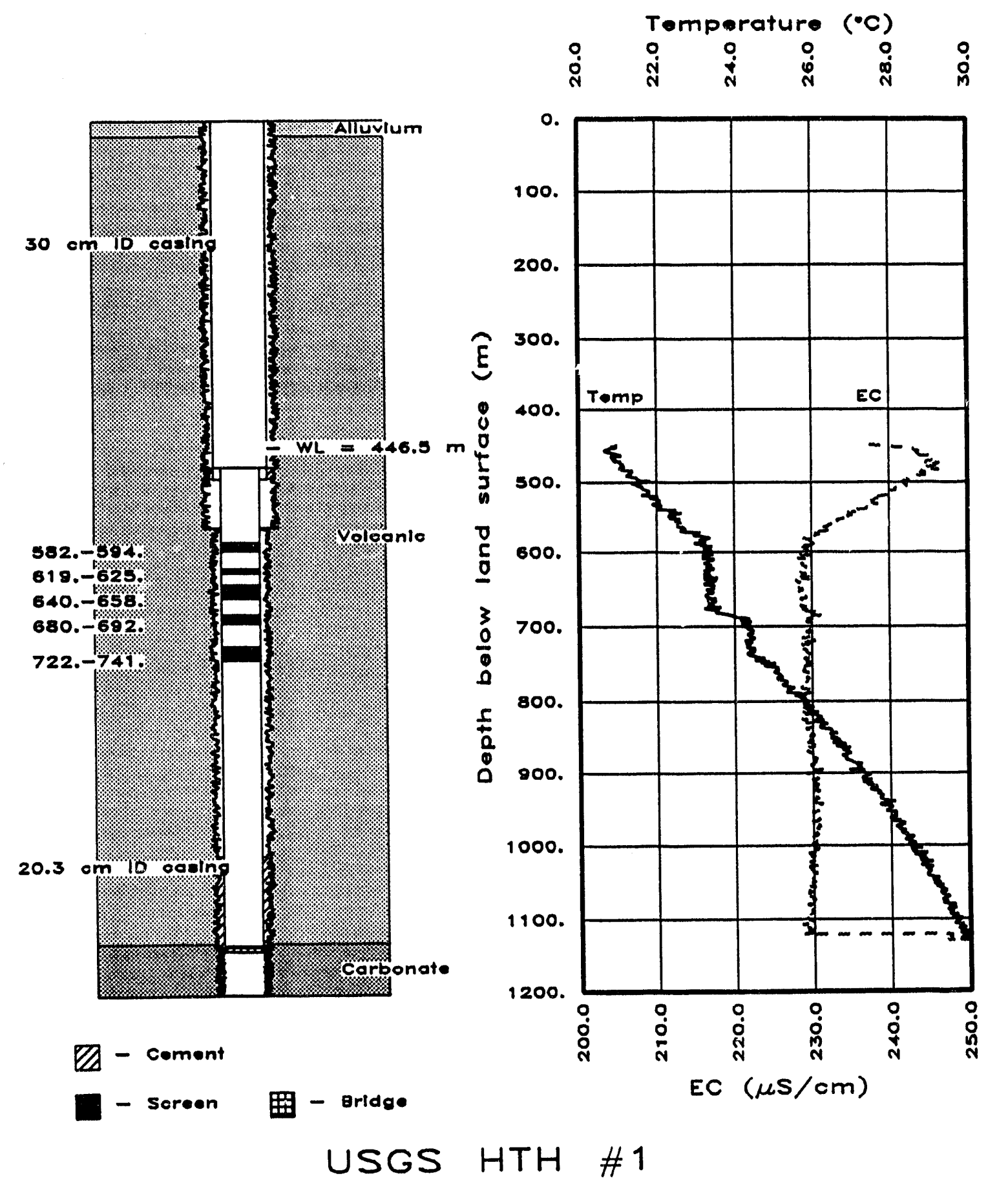

Figure 3. Generalized Well Completion Schematic and Temperature/ECLog for Well USGS HTH \#1. 
TABLE 3. GEOCHEMISTRY OF WELL USGS HTH \#1.

\begin{tabular}{lccccccc}
\hline Depth (m) & 448.0 & 460.1 & 472.1 & 473.3 & 530.2 & 588.2 & 588.2 \\
$\mathrm{Date}(\mathrm{m} / \mathrm{d} / \mathrm{y})$ & $7 / 10 / 91$ & $7 / 10 / 91$ & $9 / 24 / 90$ & $7 / 10 / 91$ & $7 / 10 / 91$ & $9 / 24 / 90$ & $7 / 10 / 91$ \\
$\mathrm{pH}(\mathrm{units})$ & 8.72 & 8.77 & 8.76 & 8.85 & 9.08 & 9.15 & 9.21 \\
$\mathrm{EC}(\mathrm{\mu} / \mathrm{cm})$ & 245 & 245 & 269 & 245 & 234 & 224 & 223 \\
$\mathrm{Ca}(\mathrm{mg} / \mathrm{l})$ & 5.35 & 5.49 & 9.83 & 5.92 & 4.21 & 1.91 & 1.96 \\
$\mathrm{Mg}(\mathrm{mg} / \mathrm{l})$ & 0.20 & 0.22 & 0.32 & 0.38 & 0.38 & 0.78 & 0.32 \\
$\mathrm{Na}(\mathrm{mg} / \mathrm{l})$ & 53.5 & 53.0 & 53.1 & 52.3 & 50.0 & 52.1 & 51.1 \\
$\mathrm{~K}(\mathrm{mg} / \mathrm{l})$ & 1.16 & 1.08 & 1.13 & 1.18 & 0.81 & 0.79 & 0.44 \\
$\mathrm{Cl}(\mathrm{mg} / \mathrm{l})$ & 3.7 & 3.8 & 3.4 & 3.8 & 3.7 & 3.3 & 3.4 \\
$\mathrm{SO}_{4}(\mathrm{mg} / \mathrm{l})$ & 8.58 & 9.74 & 17.4 & 9.5 & 8.58 & 8.76 & 7.03 \\
$\mathrm{HCO}_{3}(\mathrm{mg} / \mathrm{l})$ & 123 & 118 & 116 & 123 & 100 & 80.7 & 86.5 \\
$\mathrm{CO}_{3}(\mathrm{mg} / \mathrm{l})$ & 7.8 & 9.5 & 11.6 & 8.2 & 16.5 & 21.5 & 20.6 \\
$\mathrm{NO}_{3}(\mathrm{mg} / \mathrm{l})$ & $<0.04$ & $<0.04$ & $<0.04$ & $<0.04$ & $<0.04$ & $<0.04$ & $<0.04$ \\
$\mathrm{SiO}_{2}(\mathrm{mg} / \mathrm{l})$ & 12.0 & 12.2 & 10.7 & 12.2 & 15.5 & 19.8 & 20.2 \\
$\mathrm{Tritium}(\mathrm{pC} / \mathrm{l})^{6}$ & $60 \pm 12$ & $54 \pm 11$ & $76 \pm 9$ & $45 \pm 9$ & $30 \pm 8$ & $11 \pm 7$ & $<10$ \\
\hline
\end{tabular}

582 to $680 \mathrm{~m})\left(0.25^{\circ} \mathrm{C}\right.$ per $\left.100 \mathrm{~m}\right)$, increased sharply between the top and bottom of the fourth screen (from 680 to $692 \mathrm{~m})\left(6.7^{\circ} \mathrm{C}\right.$ per $\left.100 \mathrm{~m}\right)$, remained fairly constant between the fourth and fifth screened sections (from 692 to $731 \mathrm{~m})\left(0.25^{\circ} \mathrm{C}\right.$ per $100 \mathrm{~m}$ ), and then increased steadily from 731 to $1,129 \mathrm{~m}\left(1.4^{\circ} \mathrm{C}\right.$ per $\left.100 \mathrm{~m}\right)$. The EC trend increased from the water table $(447 \mathrm{~m})$ to $485 \mathrm{~m}$, then gradually decreased from 485 to the top of the first screen $(582 \mathrm{~m})$, and remained relatively constant for the remainder of the hole (from 582 to $1,129 \mathrm{~m}$ ) (except for the very bottom of the hole where EC increased sharply due to fill in the bottom of the well). The temperature/EC data suggest that water may be flowing up from the bottom screen, mixing with water entering the well at the fourth screen, and exiting the well at the first screen, contrary to the USGS TFM survey which basically suggested that water was flowing into the well through the top four screens and was flowing out of the well through the bottom screen and at the transition in casing. However, the data are not conclusive without detailed TFM measurements. The elevated EC and elevated tritium concentrations suggest that water may be flowing downward from the water table to the first screen; however, a review of the video log (run by Sandia National Laboratories, November 11,1989 ) does not show any obvious breaks or holes in the casing from the water table to the transition in casing. Therefore, the source and entry point of the elevated tritium is unknown. Geochemically, the water in the well is uniform from the water table to the bottom of the well, except for a slight aberration at $472 \mathrm{~m}$, which also corresponds with the elevated tritium and EC previously mentioned, again suggesting that there may be a point source of tritium and slightly different water quality near the $472 \mathrm{~m}$ depth. 


\section{Recommendations}

- A new TFM survey should be conducted to identify the inflow and outflow zones in the well, and to determine if water is entering the well from above the constriction in casing.

- Relog the well for temperature/EC to determine if the elevated EC still exists.

- The well is completed in Tertiary tuff whici may coincide with rock units in Rainier Mesa that were used for nuclear testing. Due to the elevated tritium activity detected at $472 \mathrm{~m}$, the weil should remain on the LTHMP and two samples should be collected (472 and $600 \mathrm{~m}$ below land surface) annually for radionuclides, including enriched tritium.

\section{UE-18r}

\section{Objectives}

Well UE-18r is one of only a few wells on the western boundary of the NTS; wells along this boundary are hydrologically downgradient from testing on Pahute Mesa (Blankennagel and Weir, 1973). Therefore, this well has been monitored for radionuclides as part of the LTHMP. Water samples are bailed every six months from $507 \mathrm{~m}$ below land surface. The primary objectives of this study are to determine where water is entering/exiting the well and to make recommendations about suitable radionuclide sumpling locations.

\section{Site Description}

Well UE-18r is located at the west edge of Area 18 of the NTS (Figure 1) (Nevada State Coordinates: 868,100 North (ft), 564,700 East (ft)). This well was drilled as an exploratory hole to a depth of $1,525.1 \mathrm{~m}$ in 1968 . The upper $496.5 \mathrm{~m}$ of the well was completed with 26-cm-ID casing, which was cemented in place from the bottom of the casing to land surface.

Well UE-18r was visited by DRI and USGS personnel on June 14 and 15, 1990, as part of the FY 1990 Well Validation Project. The USGS ran temperature and caliper logs on June 14. A composite log of natural gamma, long-short normal resistivity, and SP was run on the morning of June 15, and a TFM survey was conducted in the afternoon of June 15. A maximum depth of $1,509 \mathrm{~m}$ was achieved. Only preliminary data have been received from the USGS to date.

During this study, data were collected from the well on July 12,1991 by DRI personnel. Temperature/EC measurements were logged from the water table to $1,203.6 \mathrm{~m}$ (the maximum depth capability of DRI's equipment), and water samples were collected from five zones (418.3, 507.5, 762.0, 914.4, and 1,212.3 m) as specified by Lyles et al. (1991).

\section{Temperature/EC Log}

- Log Date: July 12, 1991

- Operators: Brad F. Lyles/Sam Hokett/David Gillespie

- Temperature/EC Log Summary

\begin{tabular}{|l|c|c|c|}
\hline & Depth $(\mathrm{m})$ & Temperature $(\mathrm{C})$ & $\mathrm{EC}(\mu \mathrm{S} / \mathrm{cm} @ 25(\mathrm{C}))$ \\
\hline minimum & 417.6 & 25.8 & 281.2 \\
\hline maximum & $1,203.6$ & 30.7 & 493.1 \\
\hline range & 787.3 & 4.9 & 211.9 \\
\hline
\end{tabular}

- Fluid Level: $417.6 \mathrm{~m}$

- Total Depth: $1,203.6 \mathrm{~m}$ 


\section{Logs}

The temperature/EC log is chown adjacent to the well schematic in Figure 4, and a 1-inch per 100 foot field log is included in Appendix B of this report. In the field log, English units are used for depth. The preliminary USGS log is presented in Appendix A (Morin, 1990b).

\section{Thermal Flowmeter Survey}

A TFM survey was conducted by the USGS in July 1990; only preliminary field data are available to date. This survey identified three distinct flow zones: an upper flow zone was identified with groundwater inflow at approximately $800 \mathrm{~m}$, which flowed upward, exiting the well at $579 \mathrm{~m}$, and at the water table through what was be ieved to be a hole in the casing; a lower flow zone was identified with water entering the well at $1,341 \mathrm{~m}$, flowing upward, and exiting the well at $1,097 \mathrm{~m}$, and an intermediate zone of little to no flow between the upper and lower zones (Morin, 1990a; Lyles et al., 1991). No data are available on the flow velocities or flow volumes observed during the USGS study.

\section{Geochemistry}

Water samples were collected from five discrete depths $(418.3,507.5,762.0,914.4$, and $1,212.3 \mathrm{~m}$ ). The samples were analyzed for selected ions and isotopes (Table 4). The water is characterized as a sodium-potassium bicarbonate type water, indicative of water derived from volcanic rock aquifers.

TABLE 4. GEOCHEMISTRY OF WELL UE-18r.

\begin{tabular}{|c|c|c|c|c|c|}
\hline Depth (m) & 418.3 & 507.5 & 762.0 & 914.4 & $1,212.3$ \\
\hline Date $(\mathrm{m} / \mathrm{d} / \mathrm{y})$ & $7 / 11 / 91$ & $7 / 11 / 91$ & $7 / 11 / 91$ & $7 / 11 / 91$ & $7 / 11 / 91$ \\
\hline pH (units) & 8.44 & 8.22 & 8.14 & 8.17 & 8.14 \\
\hline $\mathrm{EC}(\mu \mathrm{S} / \mathrm{cm})$ & 366 & 381 & 415 & 418 & 410 \\
\hline $\mathrm{Ca}(\mathrm{mg} / \mathrm{l})$ & 11.9 & 15.7 & 21.7 & 21.5 & 20.4 \\
\hline $\mathrm{Mg}(\mathrm{mg} / \mathrm{l})$ & 0.46 & 0.47 & 0.99 & 1.01 & 0.92 \\
\hline $\mathrm{Na}(\mathrm{mg} / \mathrm{l})$ & 73.1 & 73.1 & 75.6 & 73.8 & 74.8 \\
\hline $\mathrm{K}(\mathrm{mg} / \mathrm{l})$ & 2.1 & 2.00 & 3.49 & 3.51 & 3.35 \\
\hline $\mathrm{Cl}(\mathrm{mg} / \mathrm{l})$ & 7.5 & 7.0 & 6.9 & 6.9 & 6.9 \\
\hline $\mathrm{SO}_{4}(\mathrm{mg} / \mathrm{l})$ & 20.4 & 20.9 & 23.0 & 23.0 & 22.5 \\
\hline $\mathrm{HCO}_{3}(\mathrm{mg} / \mathrm{l})$ & 179 & 201 & 227 & 227 & 219 \\
\hline $\mathrm{CO}_{3}(\mathrm{mg} / \mathrm{l})$ & 5.2 & - & - & - & - \\
\hline $\mathrm{NO}_{3}(\mathrm{mg} / \mathrm{l})$ & $<0.04$ & 2.70 & 2.35 & 2.35 & 2.17 \\
\hline $\mathrm{SiO}_{2}(\mathrm{mg} / \mathrm{l})$ & 35.1 & 47.9 & 52.0 & 52.1 & 50.0 \\
\hline Tritium $(\mathrm{pCi} / 1)$ & $17 \pm 10$ & - & $<10$ & $<10$ & - \\
\hline
\end{tabular}




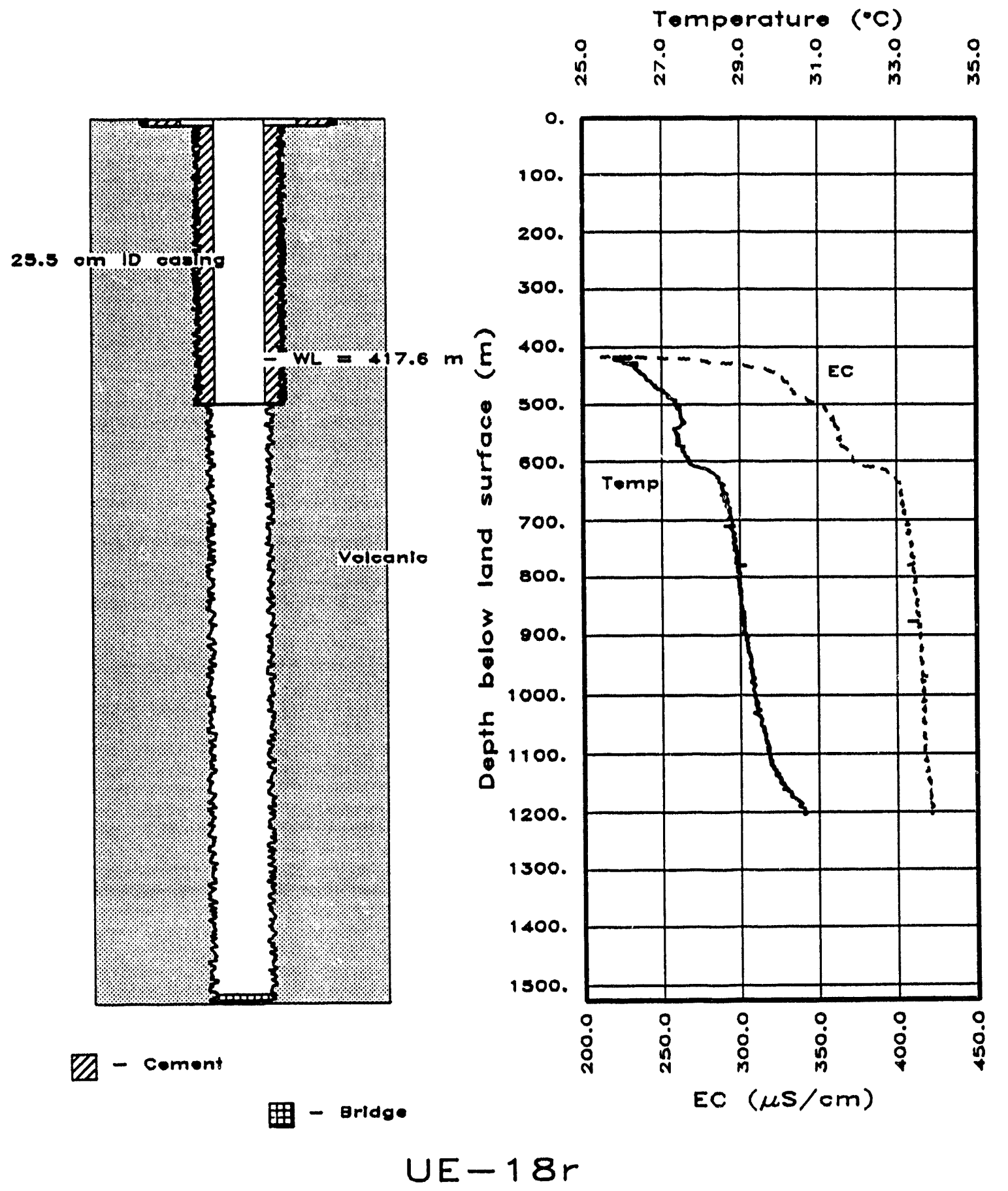

Figure 4. Generalized Well Completion Schematic and Temperature/ECLog for Well UE-18r. 


\section{Discussion and Conclusions}

The temperature/EC measurements from the well showed relatively constant trends; temperature/EC increased with increasing depth. The temperature gradient was relatively constant from the bottom of the casing $(487.7 \mathrm{~m})$ to $610 \mathrm{~m}\left(0.49^{\circ} \mathrm{C}\right.$ per $\left.100 \mathrm{~m}\right)$, increased sharply from 610 to $640 \mathrm{~m}\left(2.30^{\circ} \mathrm{C}\right.$ per $\left.100 \mathrm{~m}\right)$, remained at a fairly constant trend from 640 to $1,036 \mathrm{~m}\left(0.25^{\circ} \mathrm{C}\right.$ per $\left.100 \mathrm{~m}\right)$, and then increased from 1,036 to $1,204 \mathrm{~m}\left(0.69^{\circ} \mathrm{C}\right.$ per $\left.100 \mathrm{~m}\right)$. The EC was also relatively constant from the bottom of the casing to $610 \mathrm{~m}$ (ranging from 430 to $450 \mu \mathrm{S} / \mathrm{cm}$ ), then increased sharply from 610 to $640 \mathrm{~m}$ (ranging from 450 to $470 \mu \mathrm{S} / \mathrm{cm}$ ), and then increased steadily from 470 to $1,204 \mathrm{~m}$ (ranging from 470 to $490 \mu \mathrm{S} / \mathrm{cm}$ ). The temperature/EC data suggest that water may be flowing down from the bottom of the casing to the bottom of the borehole, with inflow between 500 and $540 \mathrm{~m}$ and outflow at 610 and 1,125 $\mathrm{m}$. Conversely, the preliminary USGS TFM survey suggests that minor outflow may be occurring at $580 \mathrm{~m}$. The geochemistry of the well is essentially constant from the bottom of the casing to $1,212 \mathrm{~m}$; the water sampled just below the water table is only slightly different (slightly lower bicarbonate, nitrate, $\mathrm{SiO}_{2}$ and calcium, and slightly increased $\mathrm{pH}$ ). The computer program WATEQ was used to compute mineral saturation indexes and the partial pressure of $\mathrm{CO}_{2}\left(\mathrm{pCO}_{2}\right)$; the water from $508 \mathrm{~m}$ is super-saturated with calcite and has a $\mathrm{pCO}_{2}$ greater than atmospheric $\left(\log \mathrm{pCO}_{2}=-2.92\right)$, and water less than $1 \mathrm{~m}$ below the water table is at equilibrium with calcite and has nearly atmospheric $\mathrm{pCO}_{2}\left(\log \mathrm{pCO}_{2}=-3.17\right)$. This suggests that calcite mineral precipitation may be occurring at the water table as the $\mathrm{CO}_{2}$ is degassed. The USGS caliper log showed a constriction within the casing at the water table, which at the time was interpneted as a break in the casing where concrete may have squeezed into the well during completion (Morin, 1990a). Therefore, further work may be necessary to determine what is occurring within the well.

\section{Recommendations}

The well is currently being investigated as a recompletion well for the GCP. The following recommendations are made with this purpose in mind and should be carried out prior to the recompletion of the well.

- Prior to recompletion, DRI's TFM should be used to more accurately measure the inflow and outflow zones that were identified in the USGS analysis.

- Run a video $\log$ of the cased portion of the well, both above and below the water table. Check this $\log$ for any evidence of mineral precipitation at or near the water table and check the casing integrity.

- The well is completed primarily in Timber Mountain tuff formation and is downgradient from underground testing areas. After recompletion, this well should be sampled annually for radionuclides as an LTHMP well.

\section{UE-14b}

\section{Objectives}

Well UE-14b is located in a region of the NTS that has not been used for underground nuclear testing; therefore, no radionuclides would be expected in this well. The primary objective of this study was to evaluate the condition of the well, the groundwater inflow and outflow zones, and water quality within the well. 


\section{Site Description}

Well UE-14b is located near Middle Valley Road in central Area 14 of the NTS (Figure 1) (Nevada State Coordinates: 794,100 North (ft), 650,111 East (ft)). This well was drilled as an exploratory hole to a depth of $1,121.6 \mathrm{~m}$ in 1984 . The upper $625.1 \mathrm{~m}$ of the well was completed with 32-cm-ID casing which was cemented in place. The first joint of casing parted in 1984 and was repaired in 1989.

During this study, data were collected from the well on July 24 and August 21, 1991. Due to equipment failures, no logs were run on July 24 , however, water samples were collected near the water table and at the bottom of the hole. On August 21, a temperature/EC $\log$ was run and samples were collected from regions identified as potential inflow and outflow zones based on the temperature/EC survey.

\section{Temperature/EC Log}

- Log Date: August 21, 1991

- Operators: Brad F. Lyles/Sam Hokett/David Gillespie

- Temperature/EC Log Summary

\begin{tabular}{|l|c|c|c|}
\hline & Depth $(\mathrm{m})$ & Temperature $(\mathrm{C})$ & $\mathrm{EC}(\mu \mathrm{S} / \mathrm{cm}$ @25 $(\mathrm{C}))$ \\
\hline minimum & 509.6 & 23.2 & 281.7 \\
\hline maximum & $1,097.8$ & 32.3 & 347.4 \\
\hline range & 588.2 & 9.1 & 65.7 \\
\hline
\end{tabular}

- Fluid Level: $508.0 \mathrm{~m}$

- Total Depth: $1,097.2 \mathrm{~m}$

\section{Logs}

The temperature/EC $\log$ is shown adjacent to the well schematic in Figure 5, and a 1-inch per 100 foot field $\log$ is included in Appendix B of this report. In the field $\log$, English units are used for depth. Two log runs were conducted at the well: logging run \#1 was in a downward logging direction and logging run \#2 was in an upward logging direction. Logging run \#1 was destroyed due to a computer error; logging run \#2 was then conducted in an upward logging direction and is included in Figure 5.

\section{Geochemistry}

Water samples were collected from four discrete depths $(512.3,761.0,1,036.3$, and $1,094.2 \mathrm{~m}$ ). The samples were analyzed for selected ions and isotopes (Table 5). The water is characterized as a sodium-potassium bicarbonate-sulfate type water, indicative of water derived from volcanic rock aquifers, although the sulfate concentrations are slightly higher than average volcanic rock aquifers.

\section{Discussion and Conclusions}

The temperature/EC measurements from the well showed relatively constant trends; temperature increased with increasing depth $\left(1.55^{\circ} \mathrm{C}\right.$ per $\left.100 \mathrm{~m}\right)$ and $\mathrm{EC}$ increased with 

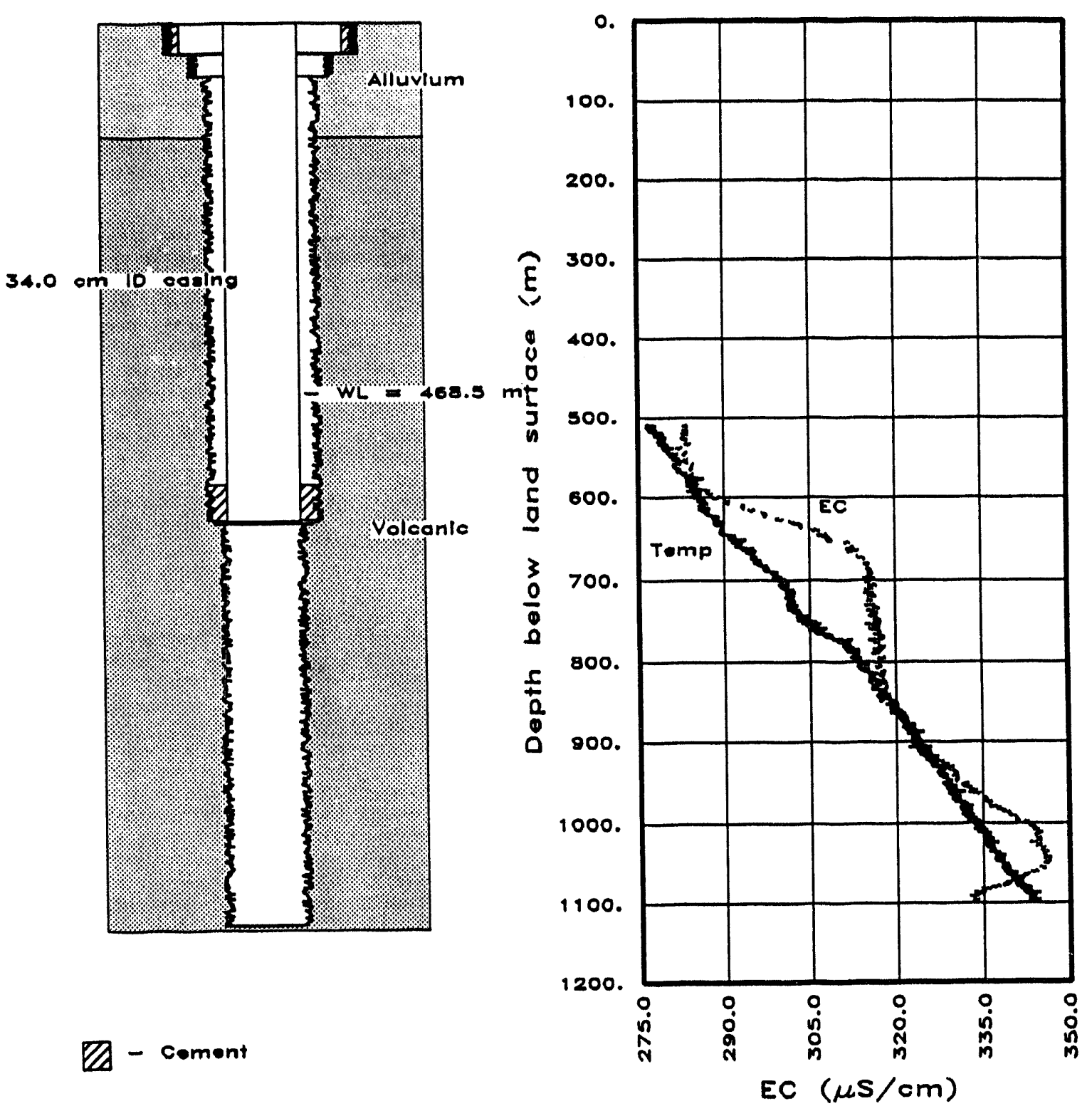

$U E-14 b$

Figure 5. Generalized Well Completion Schematic and Temperature/EC Log for Well UE-14b. 
TABLE 5. GEOCHEMISTRY OF WELL UE-14b.

\begin{tabular}{lcccc}
\hline Depth $(\mathrm{m})$ & 512.3 & 761.0 & $1,036.3$ & $1,094.2$ \\
$\mathrm{Date}(\mathrm{m} / \mathrm{d} / \mathrm{y})$ & $7 / 24 / 91$ & $8 / 21 / 91$ & $8 / 21 / 91$ & $7 / 24 / 91$ \\
$\mathrm{pH}(\mathrm{units})$ & 9.02 & 8.30 & 8.41 & 8.50 \\
$\mathrm{EC}(\mu \mathrm{S} / \mathrm{cm})$ & 346 & 389 & 428 & 410 \\
$\mathrm{Ca}(\mathrm{mg} / \mathrm{l})$ & 5.58 & 14.8 & 13.5 & 7.54 \\
$\mathrm{Mg}(\mathrm{mg} /)$ & 1.32 & 1.37 & 0.19 & 0.21 \\
$\mathrm{Na}(\mathrm{mg} / \mathrm{l})$ & 69.1 & 69.8 & 80.0 & 82.9 \\
$\mathrm{~K}(\mathrm{mg} /)$ & 2.19 & 1.45 & 1.00 & 1.23 \\
$\mathrm{Cl}(\mathrm{mg} / \mathrm{l})$ & 6.8 & 6.7 & 7.5 & 7.1 \\
$\mathrm{SO}_{4}(\mathrm{mg} /)$ & 69.5 & 68.8 & 84.9 & 80.3 \\
$\mathrm{HCO}_{3}(\mathrm{mg} / 1)$ & 76.4 & 124 & 114 & 113 \\
$\mathrm{CO}_{3}(\mathrm{mg} / 1)$ & 16.7 & 0.3 & 2.9 & 5.1 \\
$\mathrm{NO}_{3}(\mathrm{mg} / \mathrm{l})$ & 1.77 & 9.08 & 10.1 & 9.13 \\
$\mathrm{SiO}_{2}(\mathrm{mg} / \mathrm{l})$ & 9.1 & 44.1 & 43.6 & 43.6 \\
$\mathrm{Tritium}(\mathrm{pCi} / \mathrm{l})$ & $12 \pm 9$ & $<10$ & $<10$ & - \\
\hline
\end{tabular}

increasing depth $(11 \mu \mathrm{S} / \mathrm{cm}$ per $100 \mathrm{~m})$. The temperature gradient is slightly greater than what is normally observed in volcanic aquifers, suggesting the geothermal gradient in the area is slightly elevated. USGS HTH " $F$ " (a.k.a., Well F) also exhibits elevated water temperatures and is located approximately $19.3 \mathrm{~km}$ south-southeast of UE-14b. EC remained relatively constant $(280 \mu \mathrm{S} / \mathrm{cm})$ while in the casing, then increased sharply to $315 \mu \mathrm{S} / \mathrm{cm}$, remaining at that level from a depth of 680 to $850 \mathrm{~m}$. The EC then increased steadily to a second zone, where it remained relatively constant at $345 \mu \mathrm{S} / \mathrm{cm}$ between 1,000 and $1,050 \mathrm{~m}$ below land surface, and then decreased slightly at the bottom of the hole (Figure 5). The two zones of relatively constant $\mathrm{EC}$ are believed to be different waters entering the borehole and may be indicative of zones of higher transmissivity. Chemical analyses collected from the two zones showed the following differences between the upper and lower zone: sodium and sulfate ions increased while bicarbonate ions decreased. These ionic differences may simply be the result of slight lithologic variations between the two zones. The computer program WATEQ was used to compute mineral saturation indexes and the partial pressure of $\mathrm{CO}_{2}\left(\mathrm{pCO}_{2}\right)$; the water in the upper zone is super-saturated with calcite and has a pCO 2 greater than atmospheric $\left(\log \mathrm{pCO}_{2}=-3.21\right)$, and water in the lower zone is at equilibrium with calcite and nearly atmospheric $\mathrm{PCO}_{2}\left(\log \mathrm{PCO}_{2}\right.$ $=-3.40$ ). Although the water chemistry suggests that calcite mineral precipitation may occur, there was no noticeable mineral precipitation in the casing or on rocks in the open borehole as observed from the video $\log$ run by Sandia on July 24, 1991. 


\section{Recommendations}

This well is located in an area where no nuclear tests have been conducted and may be a good background groundwater monitoring well. The following recommendations are made with this purpose in mind.

- Use the TFM to measure vertical velocities at a minimum of five depths $(550,750,900$, 1,050 , and $1,100 \mathrm{~m}$ ) to identify potential inflow and outflow zones.

- Conduct a hydrochemical log of the well to delineate chemical variation twice its natural EC. Inject water softener salt over the total length of the borehole, then measure the zones of EC dilution by making consecutive EC logs.

\section{USGS TEST WELL B Ex.}

\section{Objectives}

USGS Test Well B Ex. has been sampled as a monitoring well in the LTHMP on a monthly basis from $501 \mathrm{~m}$ below land surface. Elevated tritium activity $(>50 \mathrm{pCi} / \mathrm{l})$ has been detected in this well over the past several years. The primary objectives of this study are to determine the tritium source and to recommend sampling strategies related to the LTHMP.

\section{Site Description}

USGS Test Well B Ex. (also referred to as Test Well B and TWB) is located along Tweezer Road in northeastern Area 6 of the NTS (Figure 1) (Nevada State Coordinates: 812,044 North (ft), 690,713 East (ft)). This well was drilled as an exploratory hole by the USGS in 1961. The original total depth was $510.5 \mathrm{~m}$. The upper $469.1 \mathrm{~m}$ of the well was completed with $30-\mathrm{cm}$-ID casing which was cemented near its base with $0.56 \mathrm{~m}^{3}$ of cement. A $25.4-\mathrm{cm}$-ID casing was installed from 419.1 to $509.0 \mathrm{~m}$, this casing was swaged to the $30-\mathrm{cm}$ casing at $419.1 \mathrm{~m}$ below land surface and was screened in three zones: torch cut slots from 436.5 to $442.5 \mathrm{~m}$, machine cut slots from 460.8 to $498.9 \mathrm{~m}$, and torch cut slots from 498.9 to $504.7 \mathrm{~m}$ (RSN, 1989; Moore and Garber, 1962; Moore, 1961).

During this study, data were collected from the well on August 19, 1991; at that time, a temperature/EC $\log$ was run and a sample was collected from the bottom of the well.

\section{Temperature/EC Log}

- Log Date: August 19, 1991

- Operators: Brad F. Lyles/Sam Hokett

- Temperature/EC Log Summary

\begin{tabular}{|l|c|c|c|}
\hline & Depth $(\mathrm{m})$ & Temperature $(\mathrm{C})$ & $\mathrm{EC}(\mu \mathrm{S} / \mathrm{cm} @ 25(\mathrm{C}))$ \\
\hline minimum & 458.4 & 24.5 & 300.5 \\
\hline maximum & 504.7 & 24.8 & 304.5 \\
\hline range & 46.3 & 0.3 & 4.0 \\
\hline
\end{tabular}

- Fluid Level: $458.3 \mathrm{~m}$

- Total Depth: $505.0 \mathrm{~m}$ 


\section{Logs}

The temperature/EC log is shown adjacent to the well schematic in Figure 6a, and a 5-inch per 100 foot field $\log$ is included in Appendix B of this report. In the field log, English units are used for depth. Two log runs were conducted at the well; logging run \#1 and run \#2 were in a downward logging direction. Logging run \#1 was compromised due to a problem with the logging tool; logging run \#2 was conducted after the tool was repaired at the surface and the log is included in Figures $6 \mathrm{a}$ and $6 \mathrm{~b}$.

\section{Geochemistry}

A water sample was collected at $504.4 \mathrm{~m}$ below land surface. The samples were analyzed for selected ions and isotopes (Table 6). The water is characterized as a sodium-potassium bicarbonate type water, indicative of water derived from volcanic rock aquifers.

TABLE 6. GEOCHEMISTRY OF WELL USGS TEST WELL B EX.

$\begin{array}{lclc}\text { Depth }(\mathrm{m}) & 504.4 & \mathrm{Cl}(\mathrm{mg} / \mathrm{l}) & 17.4 \\ \text { Date }(\mathrm{m} / \mathrm{d} / \mathrm{y}) & 8 / 20 / 91 & \mathrm{SO}_{4}(\mathrm{mg} / \mathrm{l}) & 21.6 \\ \mathrm{pH}(\mathrm{units}) & 8.32 & \mathrm{HCO}_{3}(\mathrm{mg} / \mathrm{l}) & 173.0 \\ \mathrm{EC}(\mu \mathrm{S} / \mathrm{cm}) & 369 & \mathrm{CO}_{3}(\mathrm{mg} / \mathrm{l}) & 0.8 \\ \mathrm{Ca}(\mathrm{mg} / \mathrm{l}) & 5.71 & \mathrm{NO}_{3}(\mathrm{mg} / \mathrm{l}) & 0.04 \\ \mathrm{Mg}(\mathrm{mg} / \mathrm{l}) & 0.63 & \mathrm{SiO}_{2}(\mathrm{mg} / \mathrm{l}) & 17.7 \\ \mathrm{Na}(\mathrm{mg} / \mathrm{l}) & 79.0 & \text { Tritium }(\mathrm{pCi} / 1) & 111 \pm 15 \\ \mathrm{~K}(\mathrm{mg} / \mathrm{l}) & 3.85 & & \end{array}$

\section{Discussion and Conclusions}

The temperature/EC measurements from the well showed relatively constant trends; temperature increased with increasing depth $\left(0.77^{\circ} \mathrm{C}\right.$ per $\left.100 \mathrm{~m}\right)$ and EC remained constant with increasing depth $(8 \mu \mathrm{S} / \mathrm{cm}$ per $100 \mathrm{~m})$. The EC increased sharply at the bottom of the hole; upon inspection of the logging tool once it was rernoved from the well, the EC cell was found to be contaminated with metal shavings and drilling mud that had a strong hydrocarbon odor. These materials may be left over from the well drilling operation or may have been inadvertently dumped in the well. The tritium concentration is slightly elevated, but is consistent with tritium levels observed previously at the well by the EPA as part of their LTHMP (Lyles, 1993).

\section{Recommendations}

The well has been part of the LTHMP for the past 17 years and should remain as part the program due to the observed elevated tritium concentrations. The following recommendations are made with this purpose in mind.

- Collect tritium samples from USGS Test Well B Ex. every six months as part of the LTHMP at $480 \mathrm{~m}$ below land surface, or every three months if tritium concentrations exceed $200 \mathrm{pCi} / 1$.

- Clean out the bottom of the well by bailing or drilling. Collect a water sample once the well has been cleaned out. 


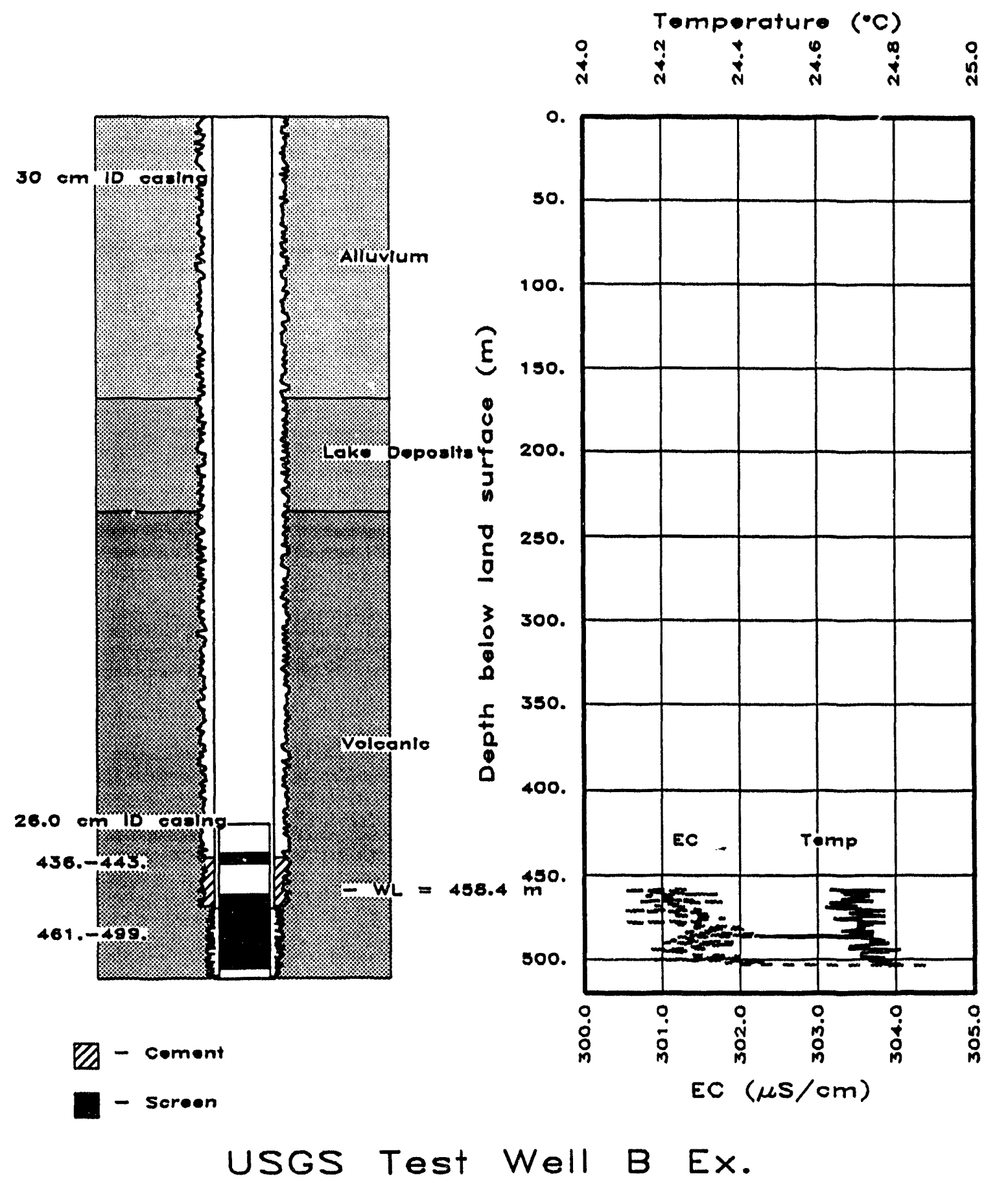

Figure 6a. Generalized Well Completion Schematic and Temperature/EC Log for Well USGS Test Well B Ex. 


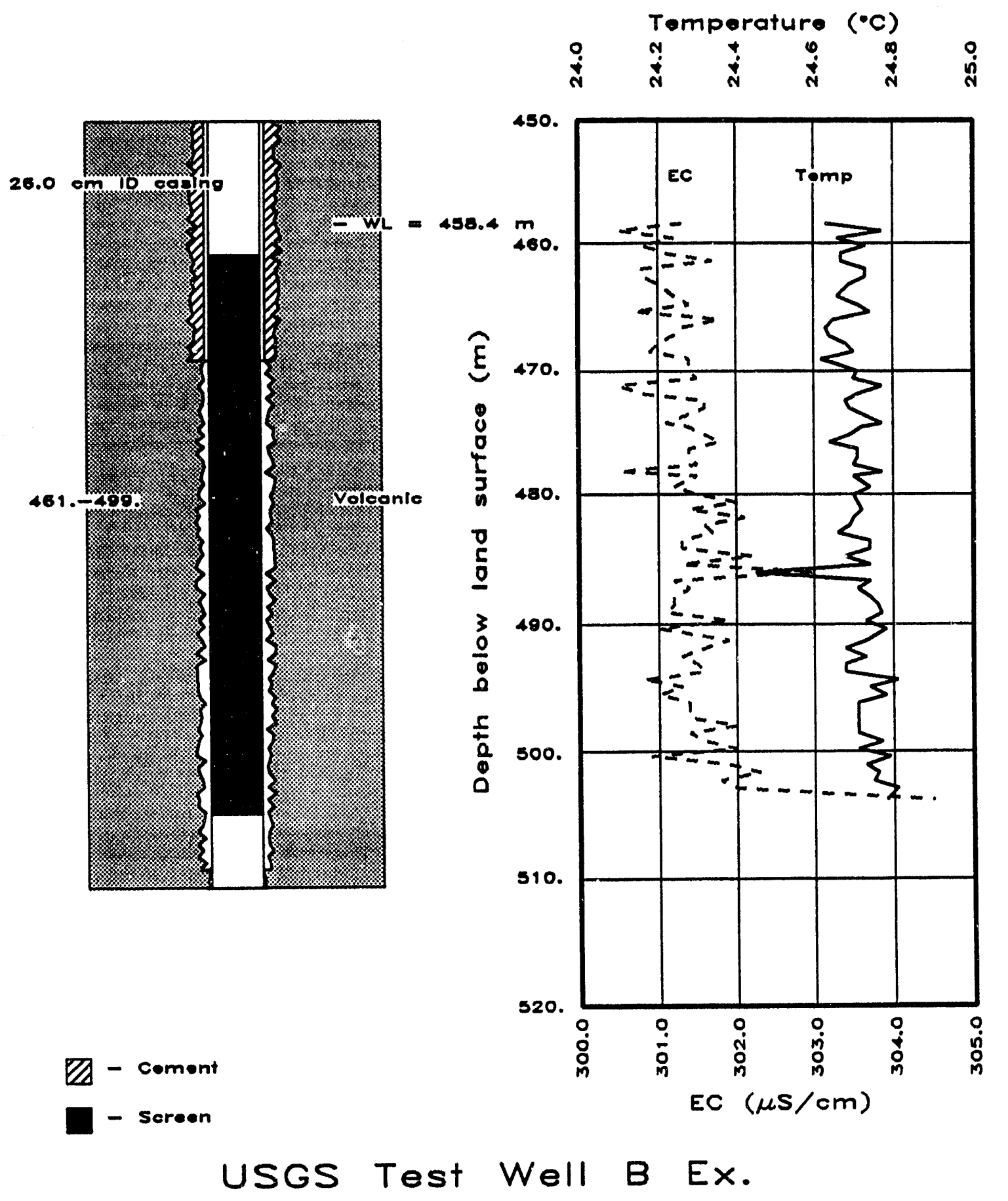

Figure 6b. Detailed View of Temperature/EC Log and Well Schematic for Well USGS Test Well B Ex. 


\section{UE-1q}

\section{Objectives}

Well UE-1q was recompleted as part of the Groundwater Characterization Program. Work included here was conducted prior to the final recompletion of the well. The objective of this study was to identify groundwater inflow and outflow zones prior to the installation of steel casing.

\section{Site Description}

UE-1q is located near BJY in northeastern Area 1 of the NTS (Figure 1) (Nevada State Coordinates: 841,500 North (ft), 677,500 East (ft)). This well was drilled as an exploratory hole in 1980. The original total depth was $742.8 \mathrm{~m}$. The upper $23.87 \mathrm{~m}$ of the well was completed with 33.9-cm-ID casing (Drellack et al., 1980). Several sloughing or caving zones were identified during completion of the well, and a washout zone at $562.9 \mathrm{~m}$ was noted from a video log run in 1984 (RSN, 1984).

During this study, data were collected from the well on August 20, 1991, and April 30 to May 1, 1992. On August 20, a temperature/EC $\log$ was made and a sample was collected from the bottom of the well. On April 30, DRI personnel conducted a temperature/EC log and a TFM survey. Logging activities were concluded on May 1 . These measurements were made during the recompletion of the well, after the bridges had been cleaned out and prior to the installation of casing (which now isolates the noncarbonate rocks from the well).

\section{Temperature/EC Log}

- Log Date: August 20, 1991

- Operators: Brad F. Lyles/Sam Hokett

- Temperature/EC Log Summary

\begin{tabular}{|l|c|c|c|}
\hline & Depth $(\mathrm{m})$ & Temperature $(\mathrm{C})$ & EC $(\mu \mathrm{S} / \mathrm{cm}$ @25 (C)) \\
\hline minimum & 472.1 & 23.0 & 287.3 \\
\hline maximum & 493.1 & 23.4 & 301.7 \\
\hline range & 21.0 & 0.4 & 14.4 \\
\hline
\end{tabular}

- Fluid Level: $473.3 \mathrm{~m}$

- Total Depth: $493.1 \mathrm{~m}$

Temperature/EC Log

- Log Date: April 30, 1992

- Operators: Brad F. Lyles

- Temperature/EC Log Summary

\begin{tabular}{|l|c|c|c|}
\hline & Depth $(\mathrm{m})$ & Temperature $(\mathrm{C})$ & $\mathrm{EC}(\mu \mathrm{S} / \mathrm{cm}$ @25 (C)) \\
\hline minimum & 473.6 & 23.3 & 464.8 \\
\hline maximum & 695.8 & 27.5 & 618.7 \\
\hline range & 222.2 & 4.2 & 153.9 \\
\hline
\end{tabular}

- Fluid Level: $473.4 \mathrm{~m}$

- Total Depth: $695.8 \mathrm{~m}$ 


\section{Logs}

The temperature/EC log measured in August 1991 is very similar to the temperature/EC log measured in April 1992, except the EC was approximately $180 \mu \mathrm{S} / \mathrm{cm}$ higher in 1992 than it was in 1991. The reason for this discrepancy is unknown, but may be related to the drilling fluids introduced during the recompletion of the well in 1992. The 1992 temperature/EC $\log$ is shown adjacent to the well schematic in Figure 7, and a 2-inch per 100 foot field log is included in Appendix B of this report for 1991 and 1992. In the field logs, English units are used for depth.

\section{Thermal Flowmeter Survey}

TFM measurements were conducted at nine discrete depths $(476.7,524.2,534.9,548.6$, $582.1,594.3,634.0,644.6$, and $695.0 \mathrm{~m}$ ). This survey was conducted prior to the TFM being outfitted with an inflatable packer; no flow was detected in the well greater than the detection limit ( $>3 \mathrm{~cm}$ per minute) for the tool at that time.

\section{Geochemistry}

A water sample was collected at $490.7 \mathrm{~m}$ below land surface. The sample was analyzed for selected ions and isotopes (Table 7). The water is characterized as a sodium-potassium bicarbonate type water, indicative of water derived from volcanic rock aquifers.

TABLE 7. GEOCHEMISTRY OF WELL UE-1q.

\begin{tabular}{lcll}
\hline Depth $(\mathrm{m})$ & 490.7 & $\mathrm{Cl}(\mathrm{mg} / \mathrm{l})$ & 5.5 \\
Date $(\mathrm{m} / \mathrm{d} / \mathrm{y})$ & $8 / 20 / 91$ & $\mathrm{SO}_{4}(\mathrm{mg} / \mathrm{l})$ & 16.0 \\
$\mathrm{pH}(\mathrm{units})$ & 8.41 & $\mathrm{HCO}_{3}(\mathrm{mg} / \mathrm{l})$ & 197 \\
$\mathrm{EC}(\mu \mathrm{S} / \mathrm{cm})$ & 371 & $\mathrm{CO}_{3}(\mathrm{mg} / \mathrm{l})$ & 4.1 \\
$\mathrm{Ca}(\mathrm{mg} / \mathrm{l})$ & 7.21 & $\mathrm{NO}_{3}(\mathrm{mg} / \mathrm{l})$ & 6.47 \\
$\mathrm{Mg}(\mathrm{mg} / \mathrm{l})$ & 2.57 & $\mathrm{SiO}_{2}(\mathrm{mg} / \mathrm{l})$ & 46.9 \\
$\mathrm{Na}(\mathrm{mg} / \mathrm{l})$ & 74.9 & $\mathrm{Tritium}(\mathrm{pCi} / 1)$ & $<15$ \\
$\mathrm{~K}(\mathrm{mg} / \mathrm{l})$ & 5.76 & & \\
\hline
\end{tabular}

\section{Discussion and Conclusions}

The temperature/EC measurements from the August $1991 \mathrm{log}$ and from the April $1992 \mathrm{log}$ show very similar trends, with temperature increasing with increasing depth and EC increasing from the water table to $550 \mathrm{~m}$, then decreasing from $550 \mathrm{~m}$ to the bottom of the hole. However, the EC is shifted about $180 \mu \mathrm{S} / \mathrm{cm}$ higher in 1992 than in 1991. The reason for this difference is unknown, but may be related to drilling fluids used during recompletion of the well. The 1992 temperature/EC log covers approximately $200 \mathrm{~m}$ more than the $1991 \mathrm{log}$. The temperature increased with increasing depth, with a gradient of $1.33^{\circ} \mathrm{C}$ per $100 \mathrm{~m}$ from the water table to 524 $\mathrm{m}$ and with a gradient of $1.94^{\circ} \mathrm{C}$ per $100 \mathrm{~m}$ from $524 \mathrm{~m}$ to the bottom of the hole. The bottom hole temperature equaled $27.3^{\circ} \mathrm{C}$. The EC increased steadily with increasing depth $(63 \mu \mathrm{S} / \mathrm{cm}$ 


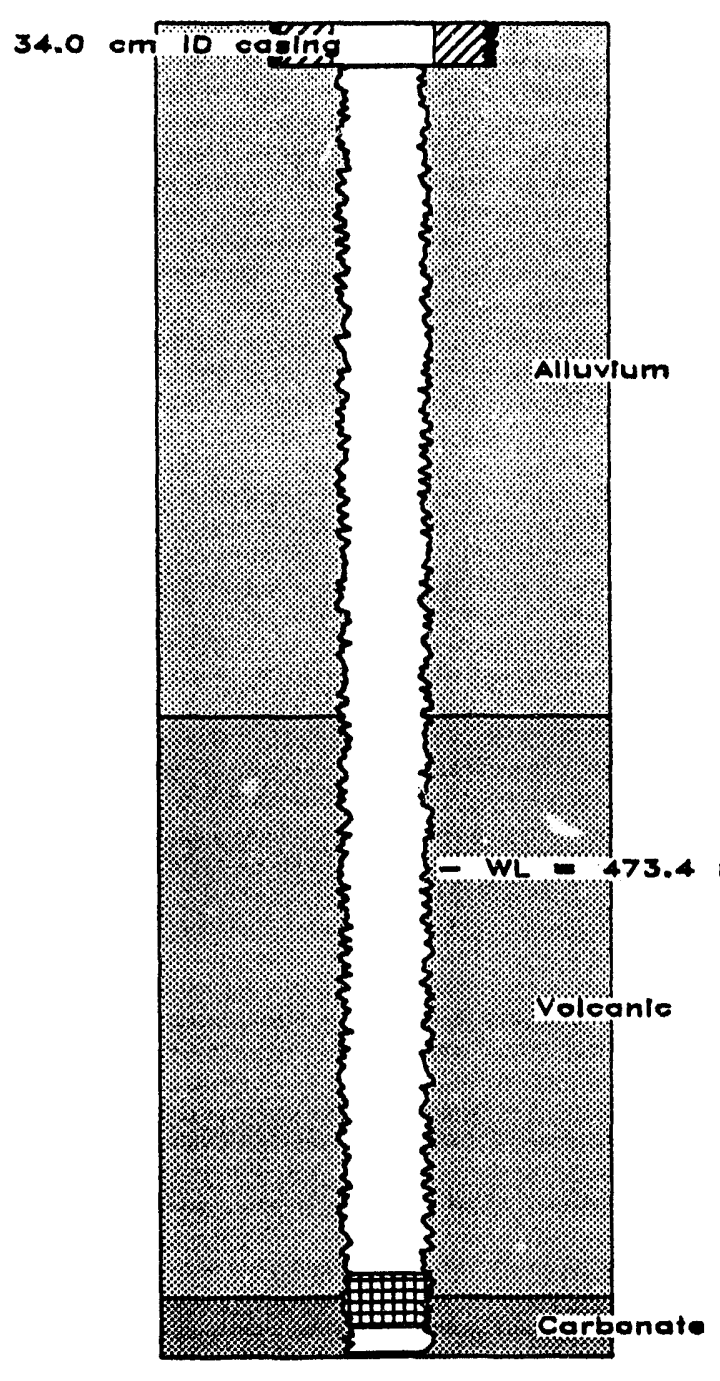

Q - coment
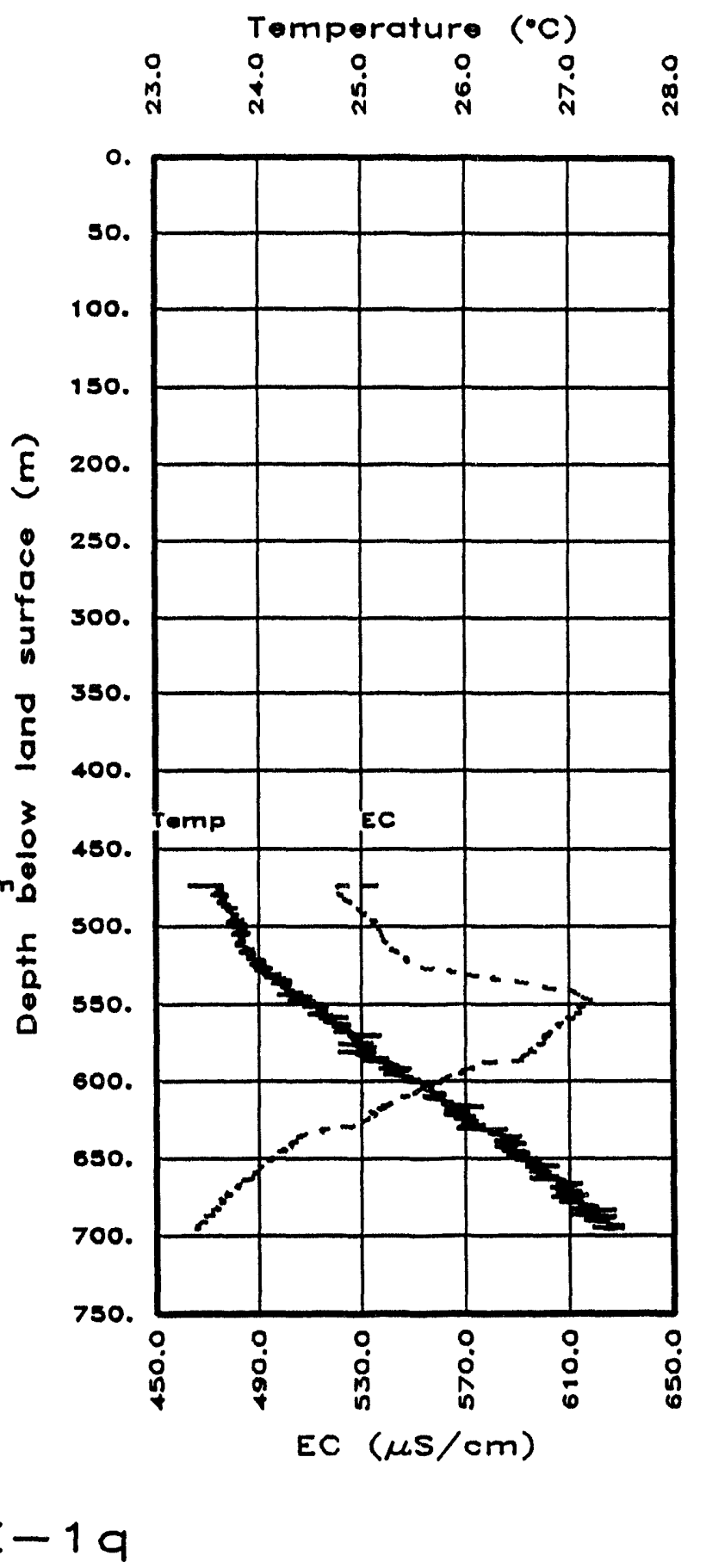

Figure 7. Generalized Well Completion Schematic and Temperature/ECLog for Well UE-1q. 
per $100 \mathrm{~m}$ ) from the water table to $524 \mathrm{~m}$, increased more rapidly $(287 \mu \mathrm{S} / \mathrm{cm}$ per $100 \mathrm{~m})$ from 524 to $548 \mathrm{~m}$, and then steadily decreased $(-105 \mu \mathrm{S} / \mathrm{cm}$ per $100 \mathrm{~m})$ from $548 \mathrm{~m}$ to the bottom of the hole. The sharp EC deviation and temperature gradient change observed at $524 \mathrm{~m}$ may be indicative of groundwater inflow, with water flowing upward from $524 \mathrm{~m}$ and exiting the wellbore near the water table. The flow rate is believed to be less than $\pm 3 \mathrm{~cm}$ per minute based on the TFM survey,

\section{Recommendations}

The well has been recompleted with steel casing cemented in place from land surface to the carbonate aquifer. An additional $60 \mathrm{~m}$ or so of carbonate rock was drilled from the well and an aquifer test was conducted. The following recommendations are made with this in mind.

- Run TFM with packer at three depths: $1 \mathrm{~m}$ below the static water level; at the bottom of the hole; and half-way between the two.

- If the well is drilled deeper in the future, use the TFM and inflatable packer to measure inflow/outflow zones.

\section{UE-5n}

\section{Objectives}

Well UE-5n was drilled as an exploration hole. A radionuclide migration experiment carried out at the Cambric site produced tritiated water $(>300,000 \mathrm{pCi} / 1$; Buddemeier and Isherwood, 1985) that flowed from the Cambric well to Frenchman Flat via an unlined earthen ditch (Cambric Ditch). Cambric Ditch is approximately $75 \mathrm{~m}$ from well UE-5n. Tritiated water flowed through this ditch for about 12 years. Therefore, the proximity of this well to the Cambric Ditch is of interest for radionuclide migration studies. The primary objectives of this study are to evaluate the accessibility and the condition of this well and to collect representative fluid sample(s) from the well.

\section{Site Description}

UE-5n is located near the Cambric Ditch in Area 5 of the NTS (Figure 1) (Nevada State Coordinates: 754,460 North (ft), 706,415 East (ft)). This well was drilled as an exploratory hole in 1976. The original total depth was $514.2 \mathrm{~m}$. The well is completed with $25.0-\mathrm{cm}$-ID casing from land surface to $464.2 \mathrm{~m}$. with perforations from 219.4 to $222.5 \mathrm{~m}$. The bottom of the well was filled with concrete (RSN, 1976).

During this study, data were collected from the well on July 23, 1992. An obstruction was found at $220.6 \mathrm{~m}$ while logging the well. Once the logging tool contacted the obstruction, a vibration was detected in the casing which stopped a few seconds after it started; the logging tool was lowered and once again the vibration was detected. It was determined that the obstruction was a large rock that was wedged in the casing at each casing collar and was subsequently dislodged by the logging tool until it became permanently lodged at $361.2 \mathrm{~m}$ below land surface. The well is currently unlocked and the rock was presumably dropped down the well by curiosity seekers. 


\section{Temperature/EC Log}

- Log Date: July 23, 195:

- Operators: Brad F. Lyles/Sam Hokett

- Temperature/EC Log Summary

\begin{tabular}{|l|c|c|c|}
\hline & Depth $(\mathrm{m})$ & Temperature $(\mathrm{C})$ & $\mathrm{EC}(\mu \mathrm{S} / \mathrm{cm} @ 25(\mathrm{C}))$ \\
\hline minimum & 215.8 & 21.9 & 363.6 \\
\hline maximum & 361.2 & 24.1 & 410.5 \\
\hline range & 145.4 & 2.2 & 46.9 \\
\hline
\end{tabular}

- Fluid Level: $214.5 \mathrm{~m}$

- Total Depth: $361.2 \mathrm{~m}$

\section{Logs}

The temperature/EC log is shown adjacent to the well schematic in Figure 8, and a 2-inch per 100 foot field log is included in Appendix B of this report. In the field logs, English units are used for depth.

\section{Geochemistry}

No water samples were collected from the well.

\section{Discussion and Conclusions}

The temperature increased steadily with increasing depth $\left(1.5^{\circ} \mathrm{C}\right.$ per $\left.100 \mathrm{~m}\right)$ and the bottom hole temperature equaled $24.1^{\circ} \mathrm{C}$. The EC also increased with increasing depth (32 $\mu \mathrm{S} / \mathrm{cm}$ per $100 \mathrm{~m}$ ), with a slightly higher gradient near the screened interval of the well. The increase in EC may be from the leaching of the concrete plug at the bottom of the well, or may be higher EC groundwater leaking through the casing or through the bottom of the hole; neither theory can be proven without further testing. Equipment failures precluded sample collection from this well.

\section{Recommendations} water.

Well UE-5n is of interest due to its proximity to Cambric Ditch - a line source of tritiated

- Collect $\mathrm{a}^{3} \mathrm{H}$ sample from $225 \mathrm{~m}$ to see if elevated tritium has made it to the water table.

- Secure the well with a locked steel cap.

- Run TFM measurements at two depths, $244 \mathrm{~m}$ and $357 \mathrm{~m}$ below land surface, to determine if water is flowing vertically within the well.

- Collect water samples from two depths, 244 and $357 \mathrm{~m}$, to determine if geochemical variations exist.

- Remove the obstruction from the well so that the entire well can be evaluated. 


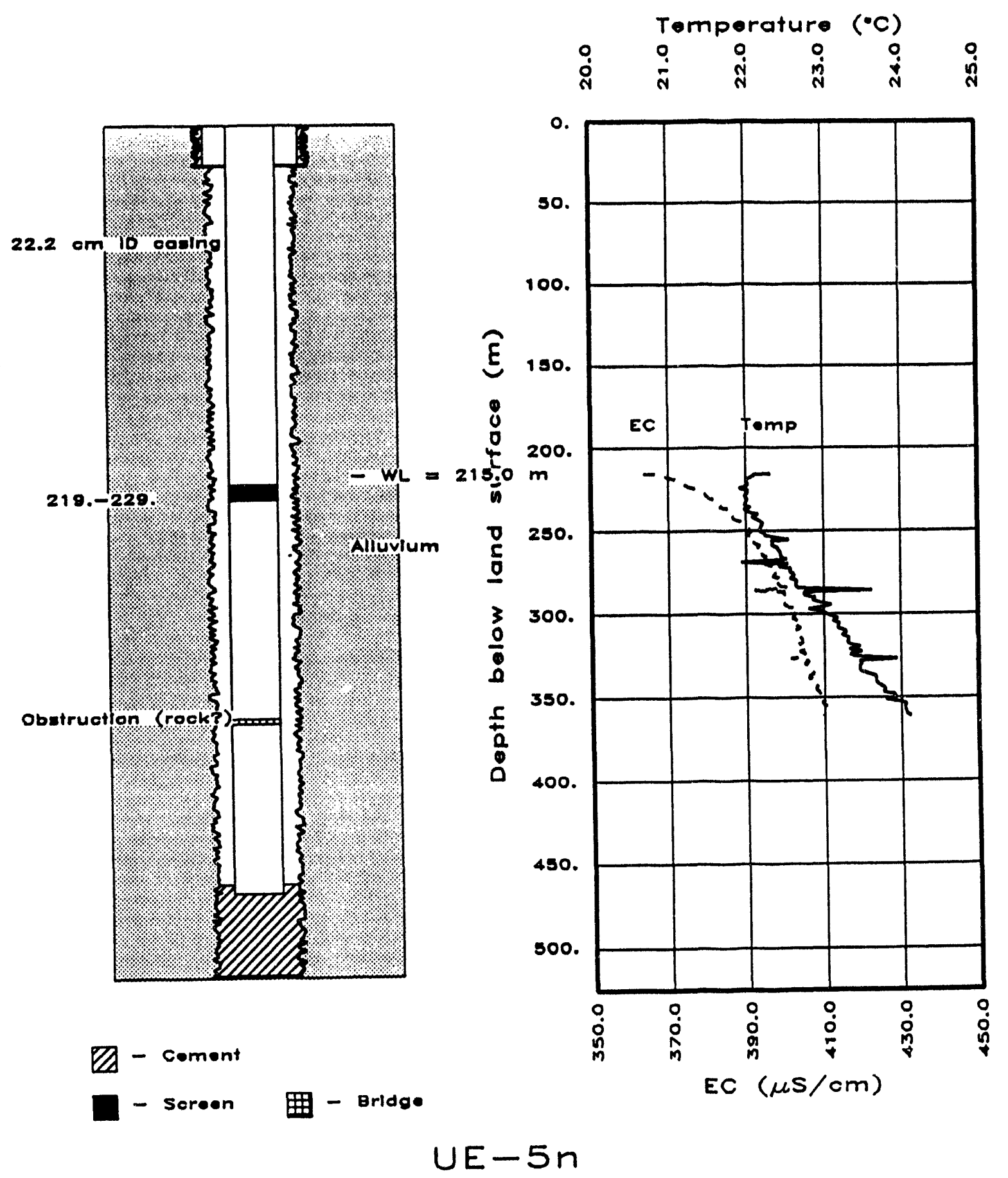

Figure 8. Generalized Well Completion Schematic and Temperature/ECLog for Well UE-5n. 


\section{SUMMARY}

Seven wells were evaluated during this study. Two wells were evaluated based on recommendations from the FY 1990 studies (Lyles et al., 1991): USGS HTH \#1 and UE-18r. Two wells were evaluated to determine their current conditions (e.g., casing condition, water level, water quality, etc.): HTH "E" and UE-5n. Well USGS Test Well B Ex. was validated to better understand the source of elevated tritium detected in the well, well UE-14b was validated to determine inflow/outflow zones in the wellbore prior to the emplacement of a pump, and well UE-1q was validated prior to and during its recompletion as part of the Recompletion Project.

Temperature/EC logs were run in most of the wells and were found to be extremely useful in determining zones of inflow/outflow and zones of differing water quality. These zones were then targeted for detailed TFM measurements and discrete sample locations.

TFM surveys yielded limited results due to the TFM's poor resolution in large-diameter boreholes. However, laboratory testing in late FY 1992 showed great promise for the TFM in larger-diameter boreholes when outfitted with an inflatable packer.

Three of the wells were recommended for sampling as part of the LTHMP due to radionuclides detected in the wells and/or from their proximity to underground nuclear tests. The wells and recommendations are:

1. USGS HTH \#1: two samples collected annually (472 and $600 \mathrm{~m}$ below land surface) for radionuclides, including enriched tritium.

2. UE-18r: one sample collected annually ( $600 \mathrm{~m}$ below land surface) for radionuclides, including enriched tritium.

3. USGS Test Well B Ex.: one sample collected every six months (480 m below land surface) for radionuclides, including enriched tritium. Sampling frequency should be increased to every three months if activities exceed $200 \mathrm{pCi} /$.

\section{ACKNOWLEDGMENTS}

The author would like to thank the technical reviewers of this report, Dr. Paul Seaber and Chuck Russell, for their comments. In addition, the author thanks Todd Mihevc, Sam Hokett, and David Gillespie for their help in developing and implementing the techniques and equipment produced as part of this study.

\section{REFERENCES}

Blankennagel, R.K. and I.E. Weir, 1973. Geohydrology of the Eastern Part of Pahute Mesa, Nevada Test Site, Nye County, Nevada. U.S. Geological Survey Prof. Paper 712-B, 35 pp.

Buddemeier, R.W. and D. Isherwood, 1985. Radionuclide Migration Project 1984 Progress Report. Lawrence Livermore National Laboratory, UCRL-53628, 71 pp.

Chapman, J.B. and B.F. Lyles, 1993. Groundwater Chemistry at the Nevada Test Site: Data and Preliminary Interpretations. Desert Research Institute, Water Resources Center, Pub. \#45100. 
Drellack, S.L., W.J. Davies and J.L. Gonzales, 1980. Unpublished data for the Geology of Well UE-1q, 10 pp.

Hess, A.E., 1990. Thermal-pulse Flowmeter for Measuring Slow Water Velocities in Boreholes. U.S. Geological Survey, Open-File Report 87-121, 70 pp.

Lyles, B.F., 1993. Tritium Activities in Selected Wells on the Nevada Test Site. Desert Research Institute, Water Resources Center, Pub. \#45104, 15 pp. (in press).

Lyles, B.F., W.A. McKay, J.B. Chapman and S.W. Tyler, 1991. Hydrogeologic Characterization of Wells HTH-1, UE18r, UE6e, and HTH-3, Nevada Test Site. Desert Research Institute, Water Resources Center, Pub. \#45087, 73 pp.

Moore, J.E., 1961. Abridged Log of Ground-water Test Well B, Yucca Flat, Nevada Test Site, Nevada. U.S. Geological Survey, Technical Letter NTS-1.

Moore, J.E. and M.S. Garber, 1962. Ground Water Test Well B, Nevada Test Site, Nye County, Nevada. U.S. Geological Survey, TEI-808, 39 pp.

Morin, R., 199Ca. Personal Communication. U.S. Geological Survey, Borehole Geophysics Research Project, June 15, 1990, at the Nevada Test Site.

Morin, R., 1990b. Written Communication. U.S. Geological Survey, Borehole Geophysics Research Project, December 24, 1990.

Raytheon Services Nevada (RSN), 1976. Unpublished hole history of Well UE-5n.

Raytheon Services Nevada (RSN), 1984. Unpublished hole history of Well UE-1q.

Raytheon Services Nevada (RSN), 1989. Unpublished hole history of Well USGS Test Well B Ex.

Raytheon Services Nevada (PSN), 1991. Unpublished hole history of Well HTH "E". 


\section{APPENDIX A}

\section{Preliminary Data from the U.S. Geological Survey's Investigation of Well UE-18r from June 15, 1990}




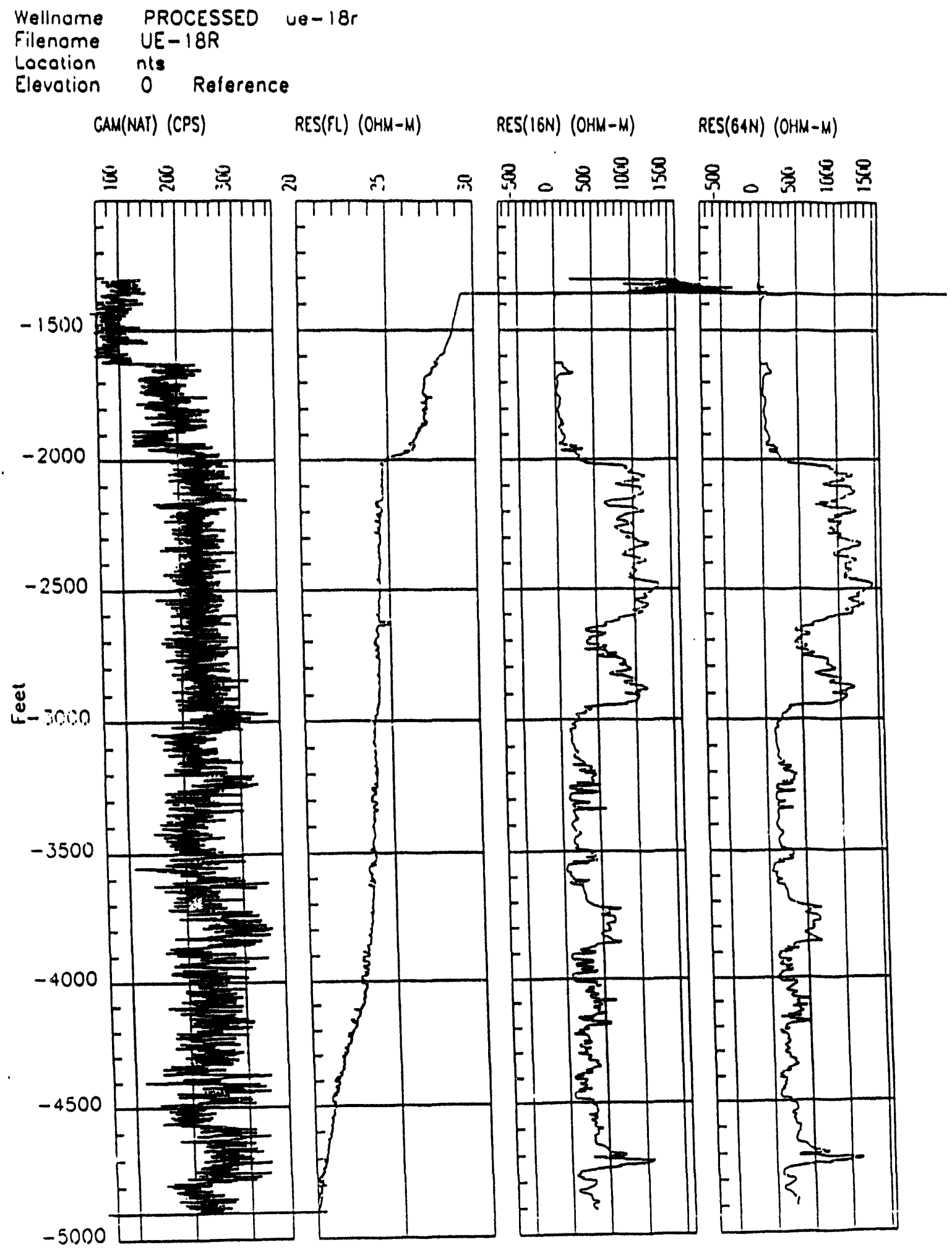




\section{APPENDIX B}

\section{Temperature and EC Logs for Well UE-14b, Well UE-18r, Well USGS HTH \#1, Well UE-1q, Well USGS Test Well B Ex., and Well UE-5n}




\section{--, Temperature and EC Log -- \\ Desert Research Institute}

Temperature and EC Log Dato

Well Name

:UE-14b

Location

Log Date

:Area 14 NTS

Operator

:21 AUG 91

Tool

:B.F. Lyles; S. Hokett; D. Gillespie

Cal Date

:T1

Casing Diameter

$: 19$ AUG 91

Casing Stick-up

$: 13.4$ inches

$: 1 \mathrm{ft}$

Depth Meosurement Datum:Land Surface

TD Drilled

$: 3680 \mathrm{ft}$

Hole Bottom

$: 3600 \mathrm{ft}$

Land Elevation ( $\mathrm{ft}$ ) $\quad: 4353.4 \mathrm{ft}$

Depth to Water $(\mathrm{ft}) \quad: 1666.6 \mathrm{ft}$

Logging Speed $(\mathrm{ft} / \mathrm{min}) \quad:-20$ 
Input file name: ue14bu.dat

Logging time start 12:14 end 14:20

\begin{tabular}{lrrr} 
& \multicolumn{1}{c}{ Min } & \multicolumn{1}{c}{ Max } & Range \\
Depth(ft) & 1672.0 & 3602.0 & 1930.0 \\
Temp (C) & 23.2 & 32.3 & 9.1 \\
EC (uS/cm) & 281.7 & 347.4 & 65.7
\end{tabular}

Upward logging direction

- Scale Factors

Depth (ft/in): 100.0

EC (us/in) : 10.0

Temp (C) : 1.0 


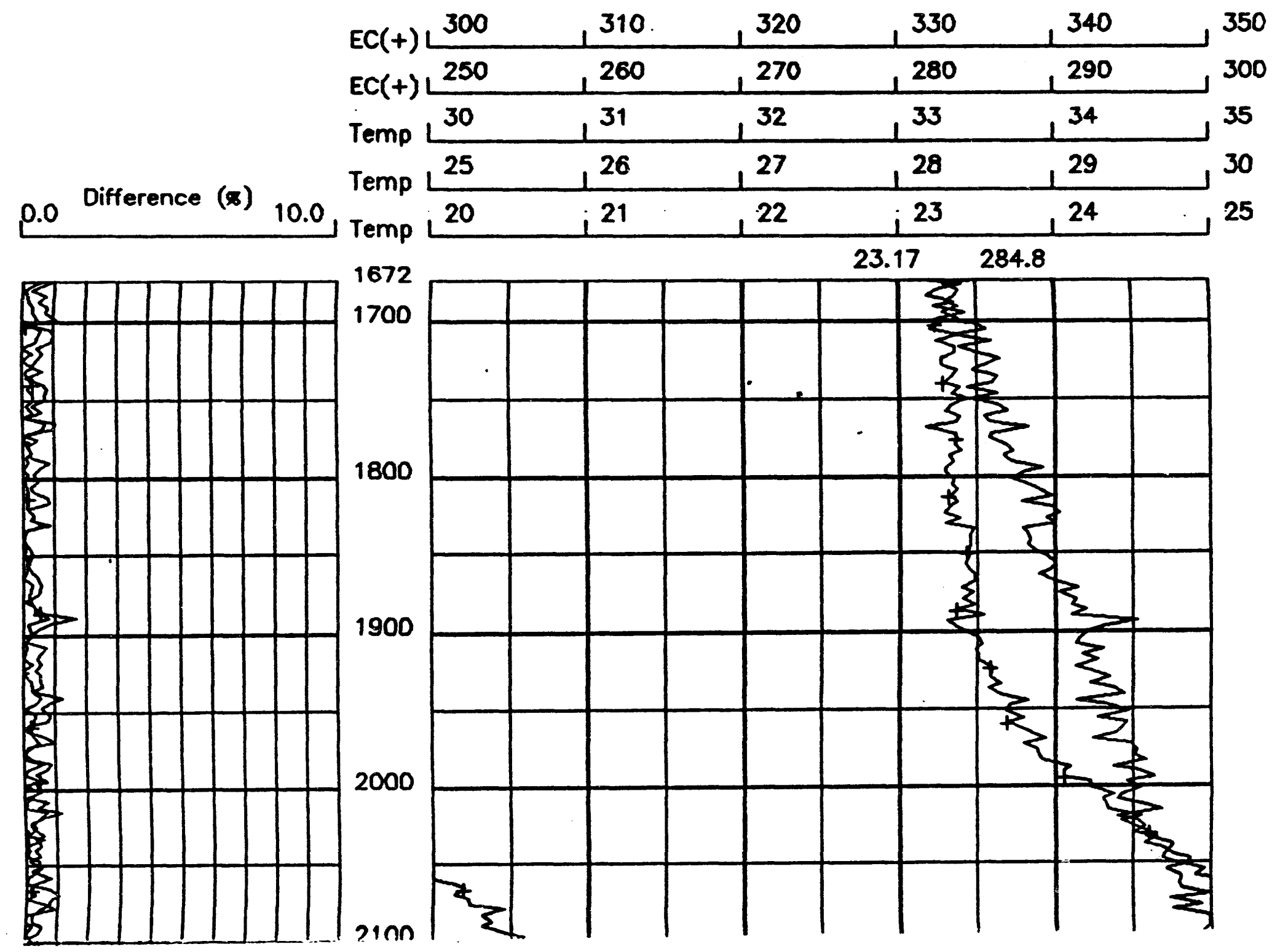




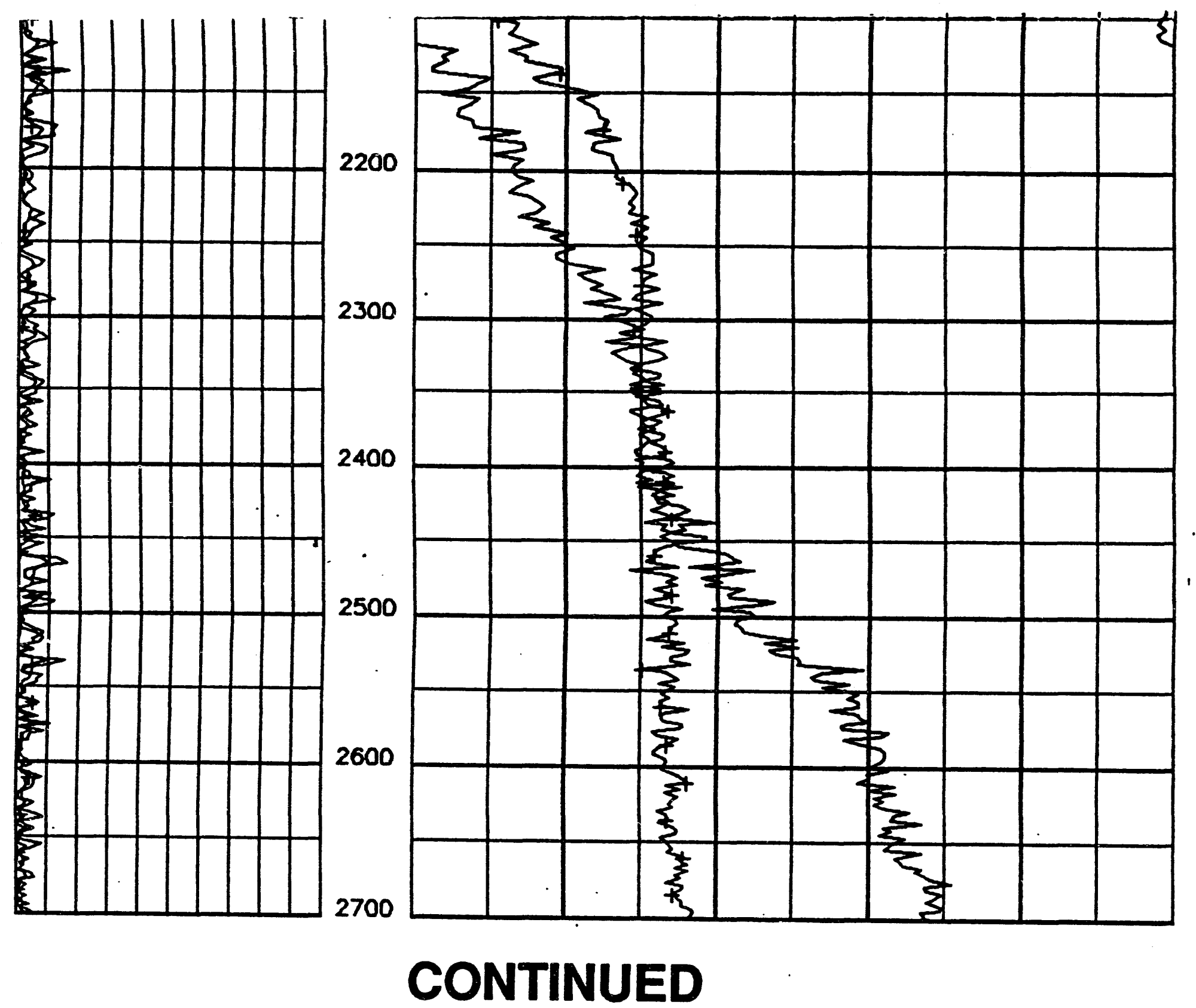




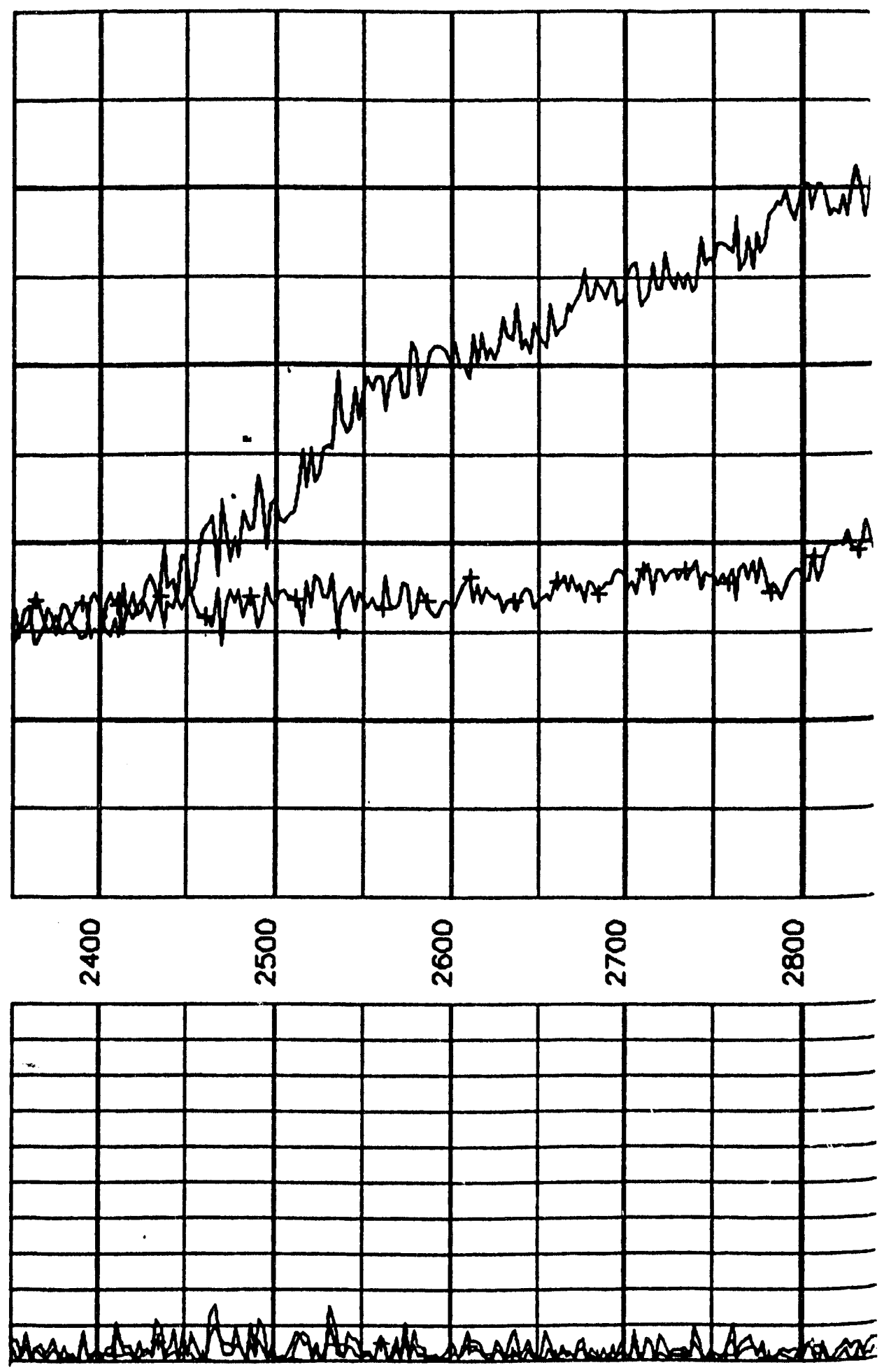




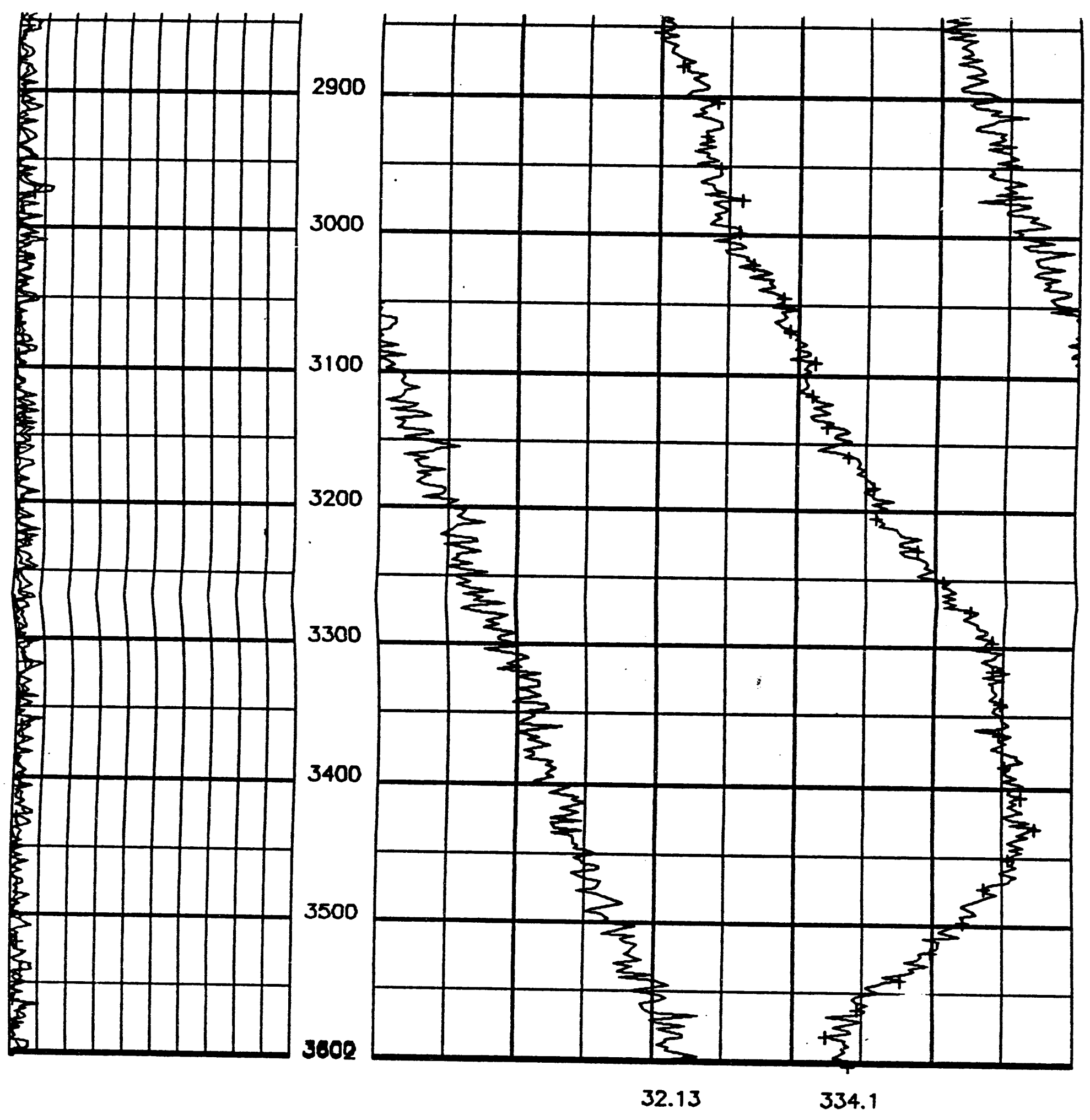




\section{-- Temperature and EC Log -- \\ Desert Research Institute}

Temperature and EC Log Dato

Well Name

Location

Log Date

Operator

Tool

Cal Date

Casing Diameter

Casing Stick-up

Depth Meosuremient Datum:Land Surface

TD Drilled

Hole Bottom

Land Elevation ( $\mathrm{ft}$ )

Depth to Water ( $\mathrm{ft}$ )

Logging Speed (ft/min)
:UE-18r

:Area 18 NTS

$: 12$ JUL 91

:BF Lyles / S Hokett / D Gillespie

:Small Stainless

$: 10$ JUL 91

$: 10.05$ in

$: 2.4 \mathrm{ft}$

$: 5004$

$: 3949$

$: 5538.2$

$: 1370$

:20 downward

Water samples were collected from 1370, 1665, 2500,

znnn nnd annn s.-1. E. , .. 
unu, uru tuwe leel, lor tritium and gross.

This is the first run of this tool design; which

consisted of a bechman probe and a YSI meter up-hole.

The hole was logged downward.

Input file name: run1.dat

Logging time start 15: 4 end 17: 2

Min Max Range

EC (uS/cm) $281.2 \quad 493.1 \quad 211.9$

Downward lagging direction

- Scale Factors

Depth (ft/in): 100.0

EC (uS/in) : 50.0

Temp (C) : 1.0 


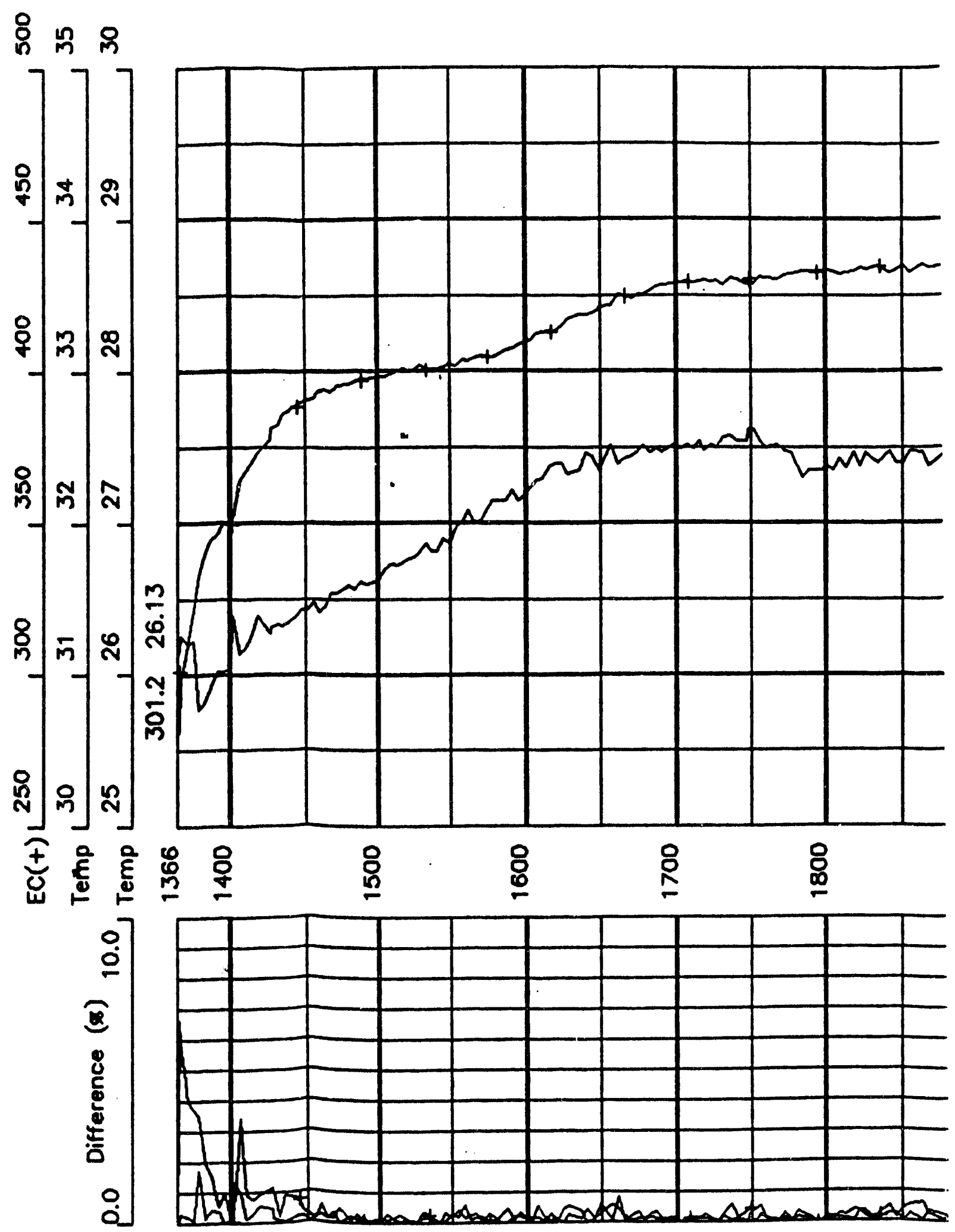




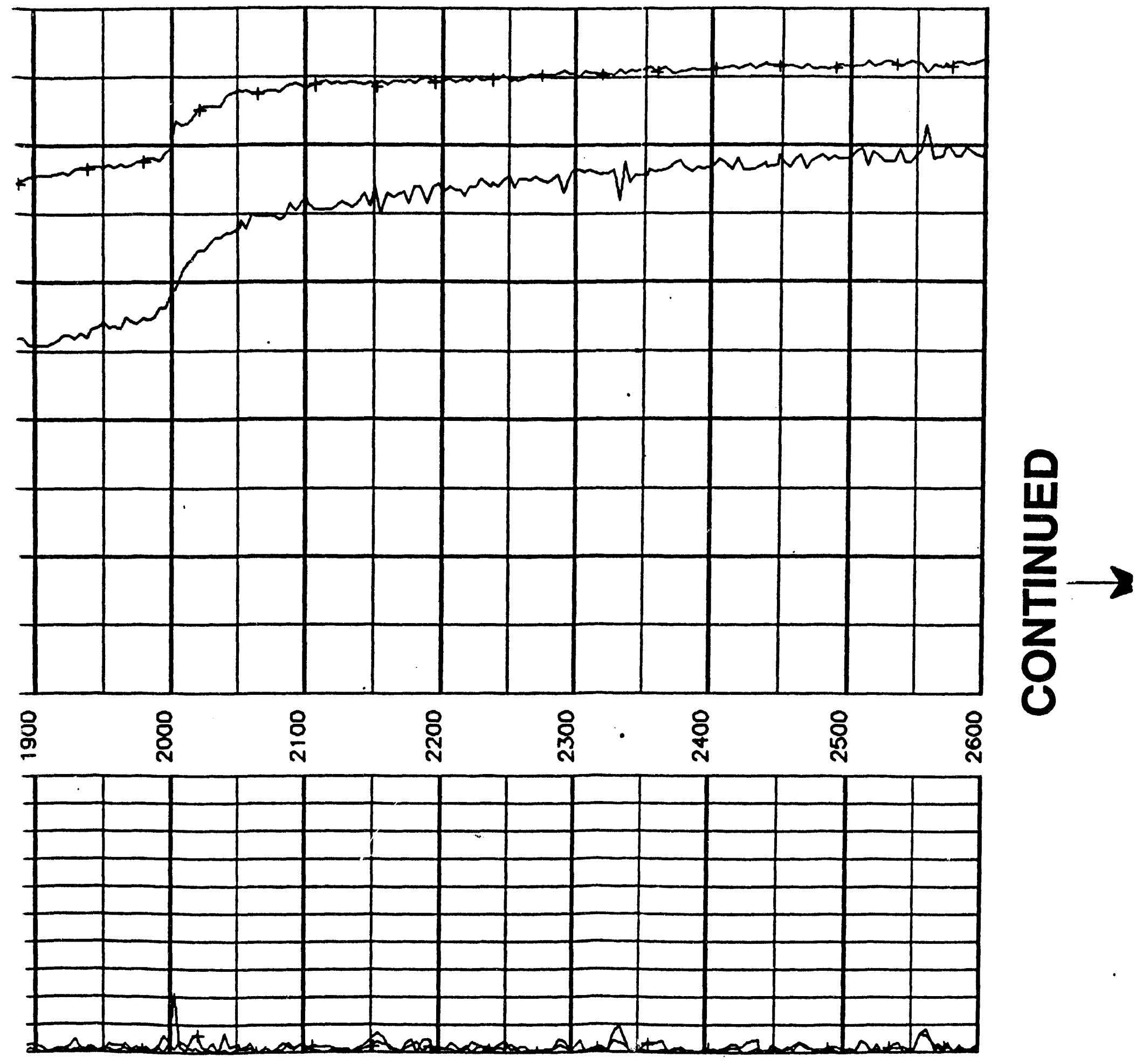




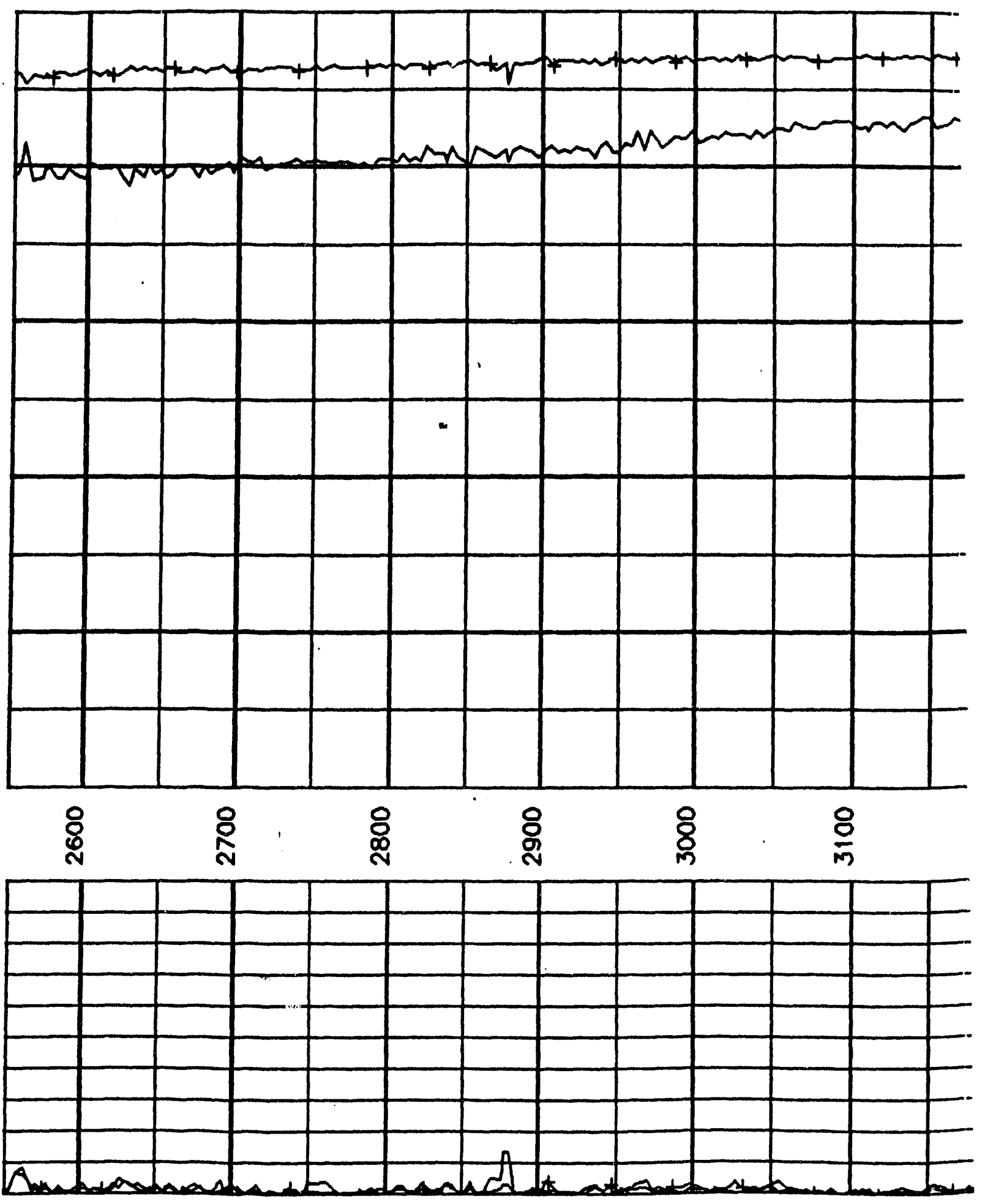




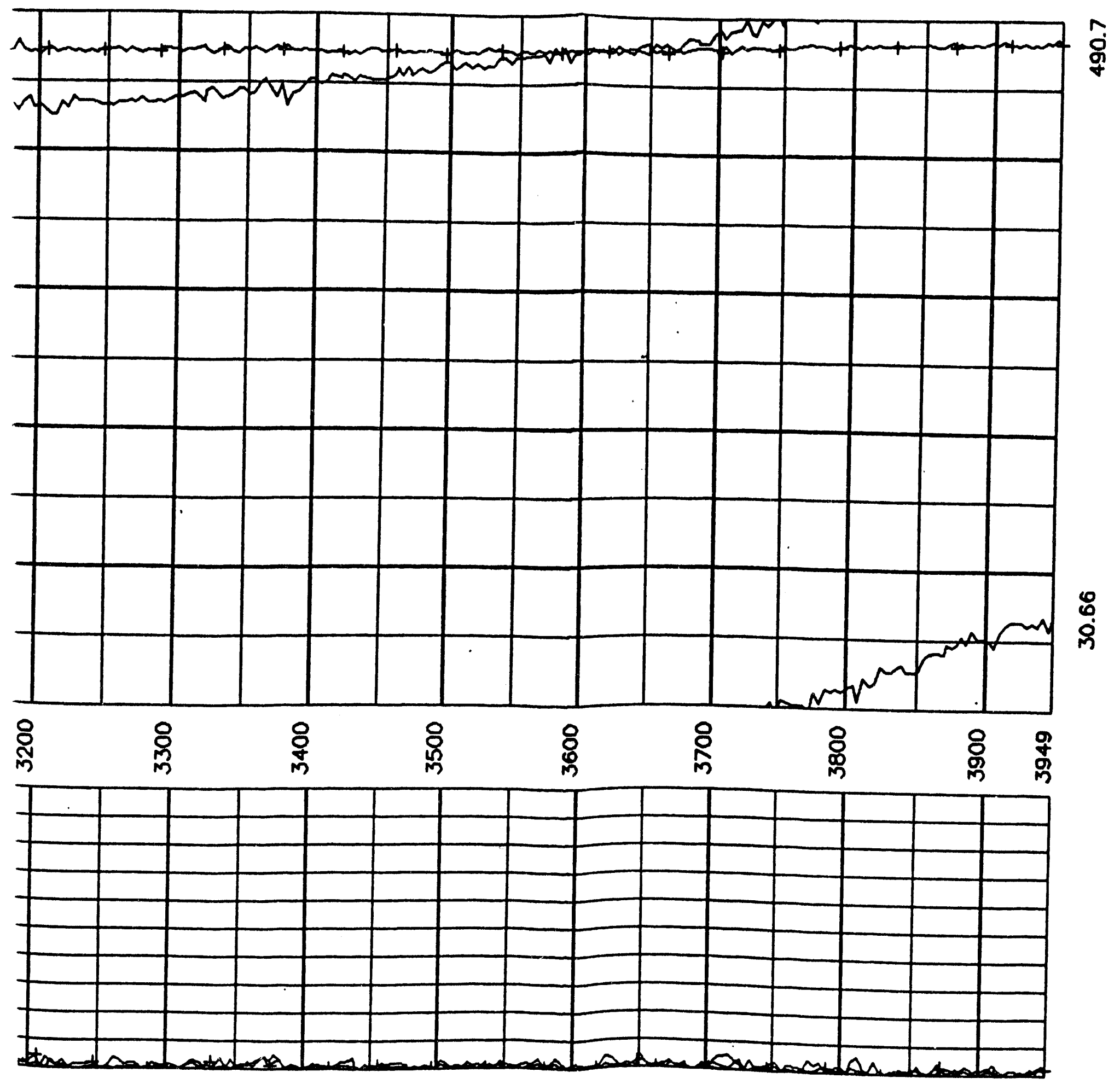




\section{-- Temperature and EC Log --}

Desert Research Institute

Temperature and EC Log Dato

Well Name

:USGS HTH $\# 1$

Location

:Areo 17 NTS

Log Date

:20 AUG 91

Operator

Tool

:S Hokett, D Gillespie, B. Lyles

:T1

Cal Date

:19 AUG 91

Casing Diameter

Casing Stick-up

$: 11$ in to $1615 \mathrm{ft} ; 8$ in to $3694 \mathrm{ft}$

$: 0.4 \mathrm{ft}$

Depth Measurement Datum:Land Surface

TD Drilled

:4206 ft

Hole Bottom

$: 3694 \mathrm{ft}$

Land Elevation ( $\mathrm{ft}$ )

$: 6155.8 \mathrm{ft}$

Depth to Water ( $\mathrm{ft}$ )

$: 1465.0 \mathrm{ft}$

Logging Speed (ft/min) :20 downward

Input file name: hth1d.dat

Logging time start 18: 5 end 19:37

a:-

a.... 


\begin{tabular}{lcrr} 
& ivil' & \multicolumn{1}{c}{ mux } & ininge \\
Depth(ft) & 1465.0 & 3705.0 & 2240.0 \\
Temp (C) & 20.6 & 30.1 & 9.4 \\
EC (uS/cm) & 153.7 & 197.9 & 44.2 \\
Downward lagging direction & & \\
- Scale Factors - & & \\
Depth (ft/in): & 100.0 & & \\
EC (uS/in) : & $10.0:$ & & \\
Temp (C) : & 2.0 & &
\end{tabular}




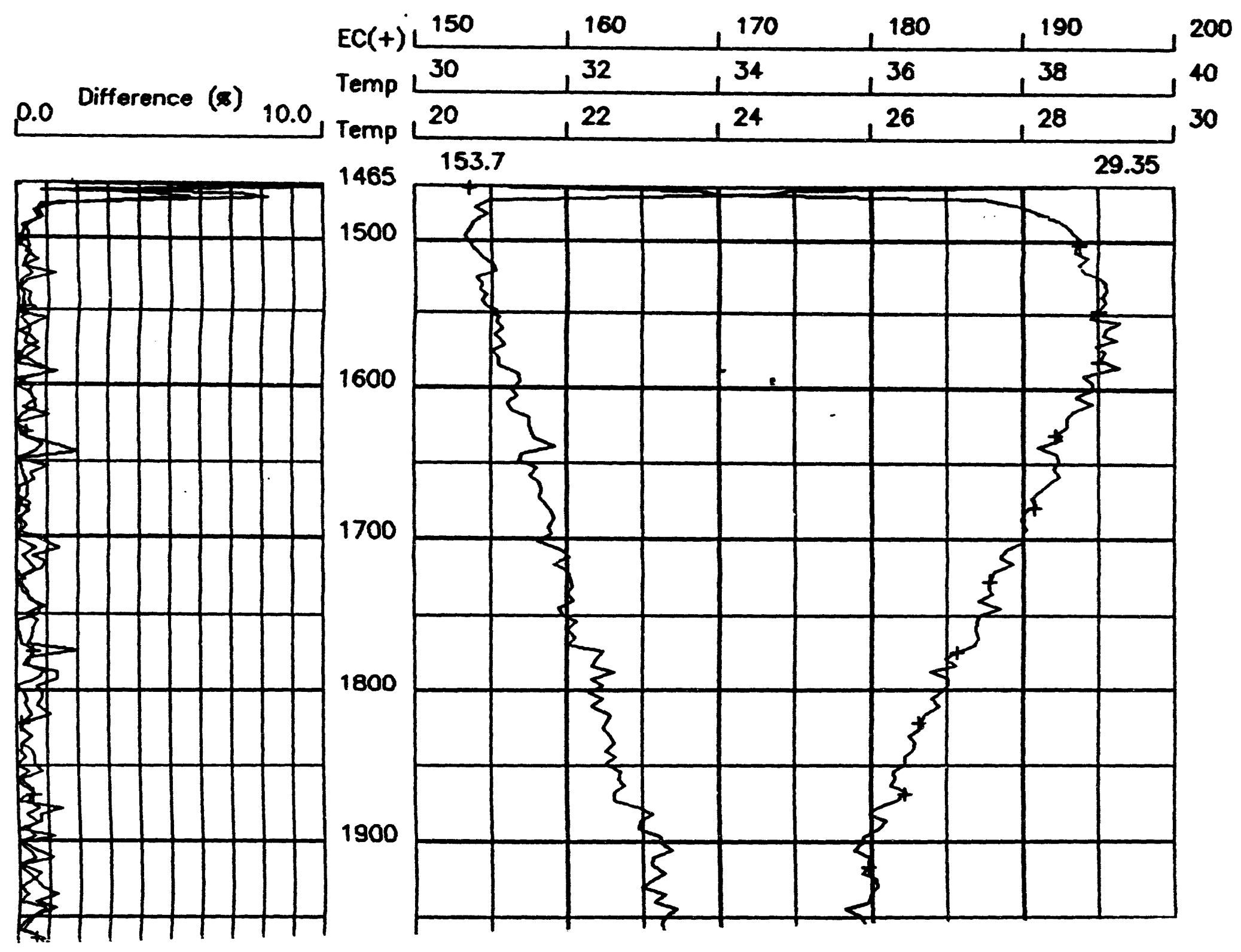




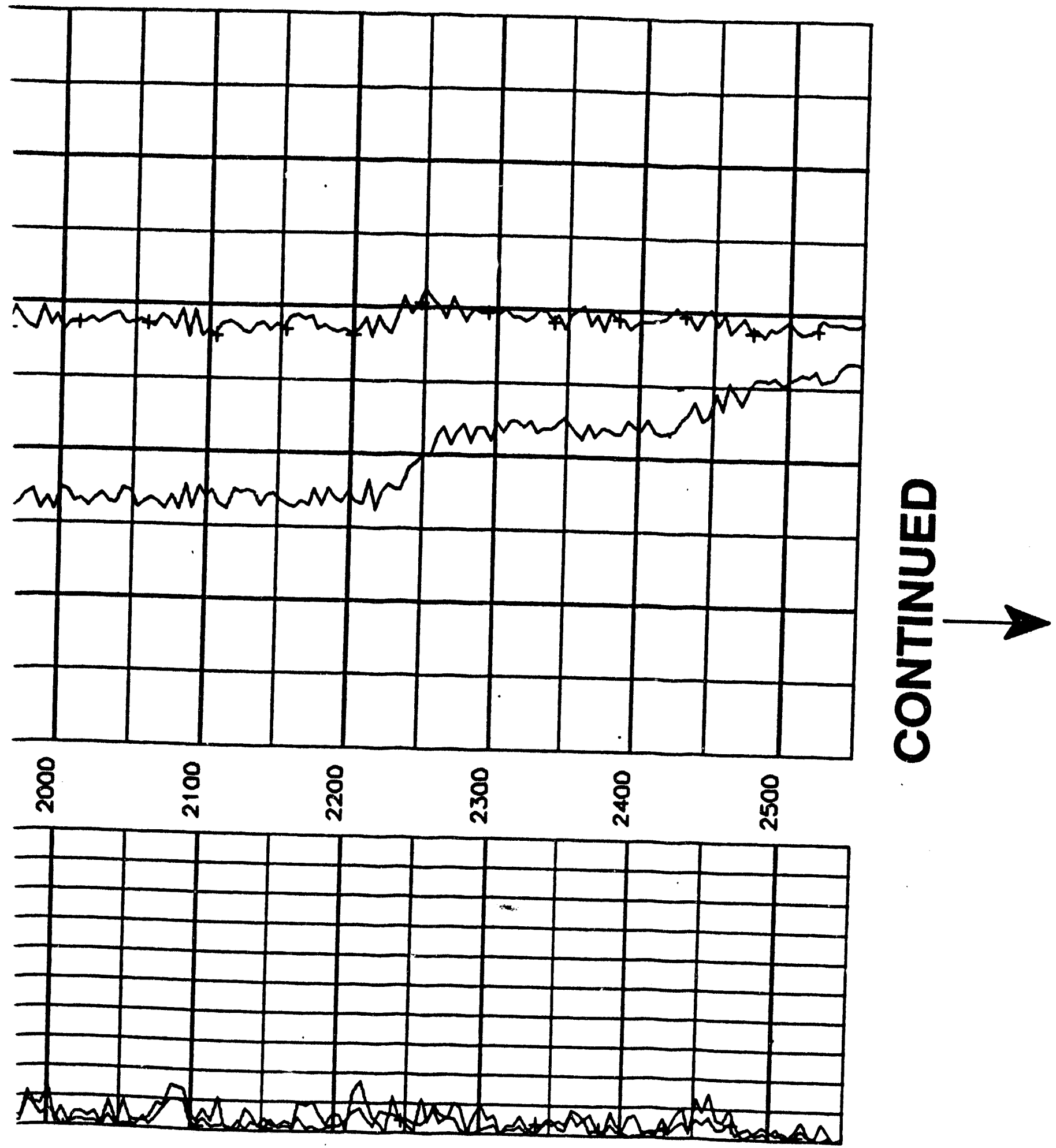




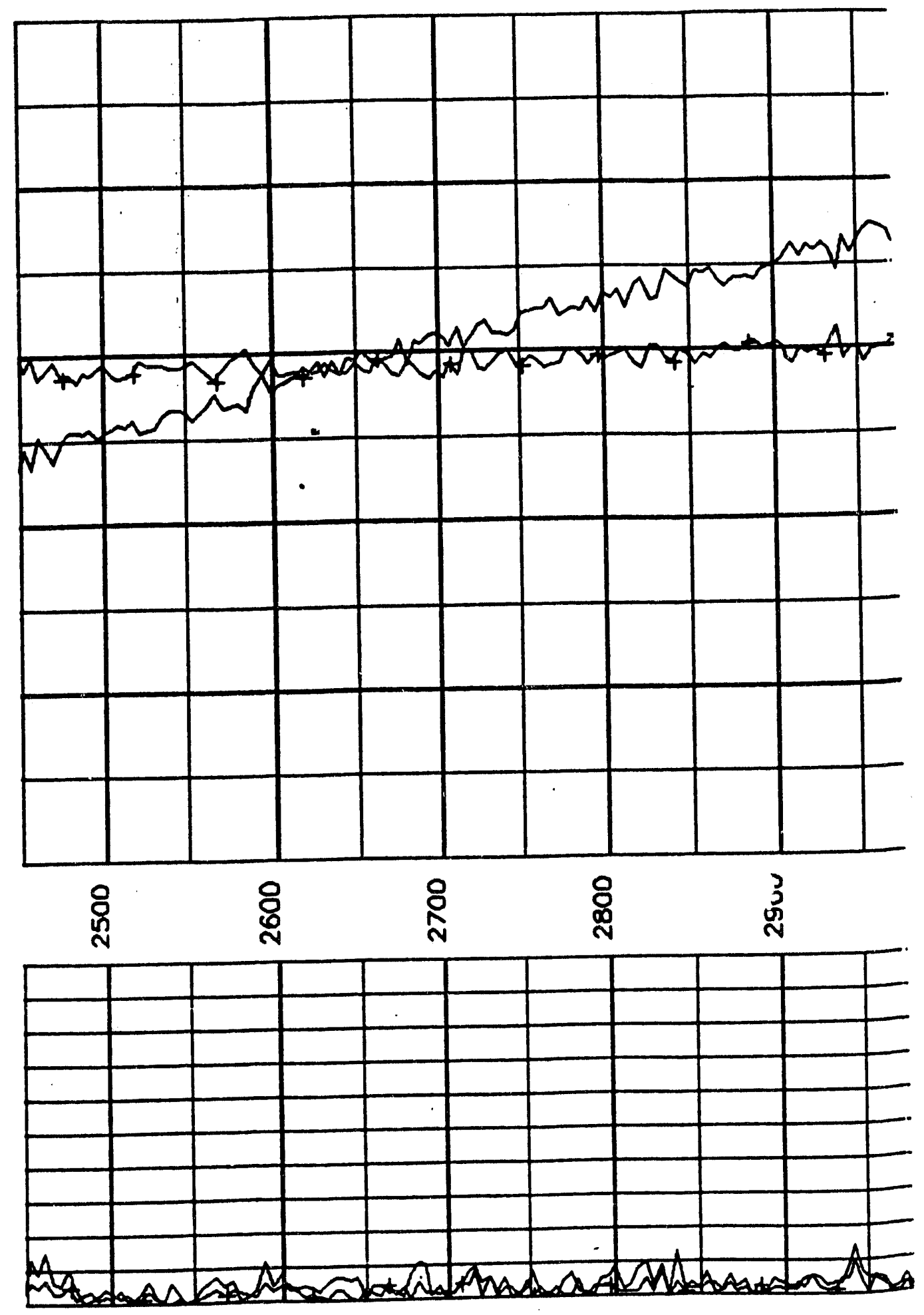




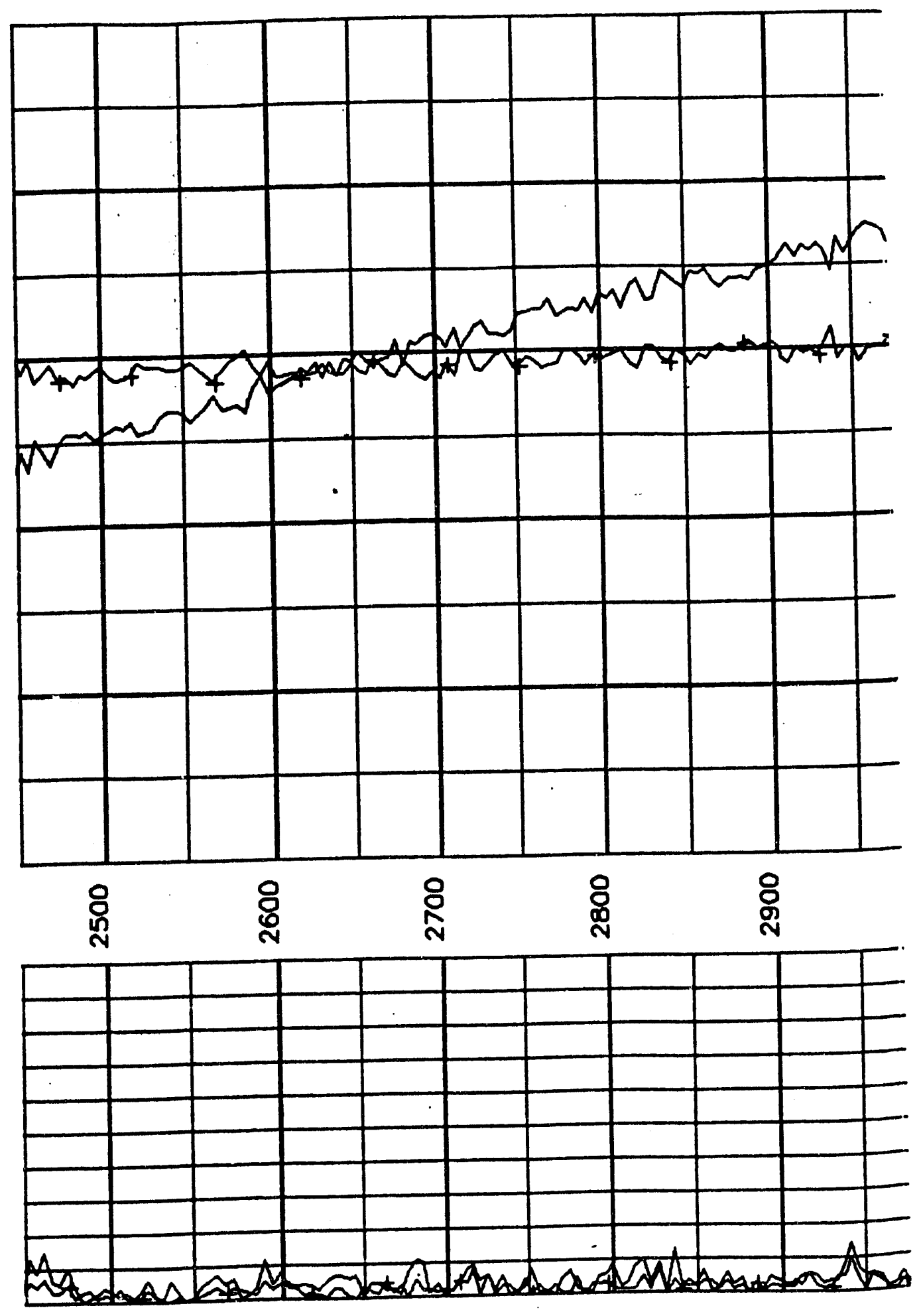




\section{-- Temperature and EC Log --}

Desert Research Institute

Temperature and EC Log Data

Well Name

:UE-1q

Location

:Areo 1 NTS

Log Date

20 AUG 91

Operator

:B.F. Lyles; S. Hokett

Tool

$: \pi 1$

Cal Date

$: 19$ AUG 91

Casing Diameter

$: 13.4$ inch

Casing Stick-up

$: 1.5$ feet

Depth Measurement Datum:Land Surface

TD Drilled

$: 2437 \mathrm{ft}$

Hole Bottom

$: 1615.4 \mathrm{ft}$

Land Elevation ( $\mathrm{ft}$ )

$: 4081.6 \mathrm{ft}$

Depth to Water ( $\mathrm{ft}$ )

$: 1552.8 \mathrm{ft}$

Logging Speed $(\mathrm{ft} / \mathrm{min})$ :10 downward

Hit bridge at $1615.4 \mathrm{ft}$, logged coming out of hole also.

Input file name: ue1qd.dat

Logging time start $13: 51$ end 13:57

$\begin{array}{cccr} & \text { Min } & \text { Max } & \text { Range } \\ \text { Depth }(\mathrm{ft}) & 1549.0 & 1618.0 & 69.0\end{array}$ 


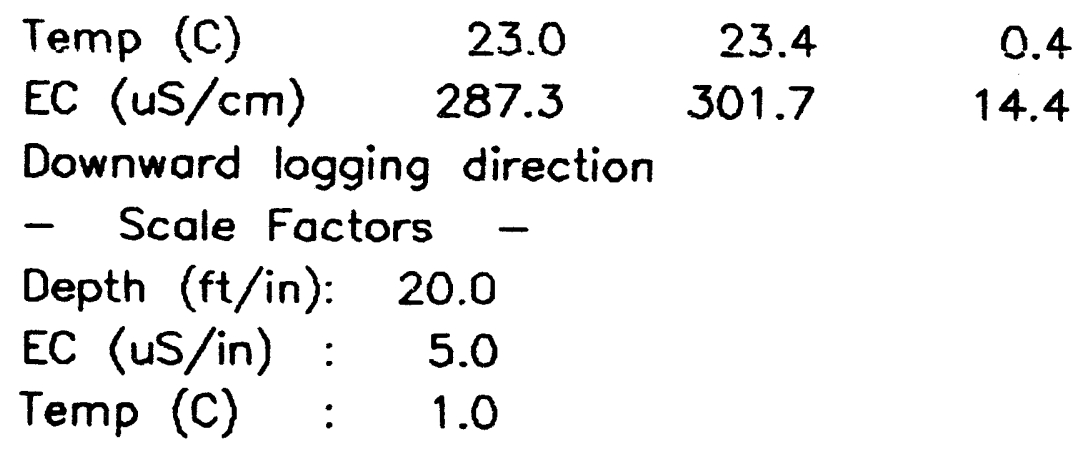




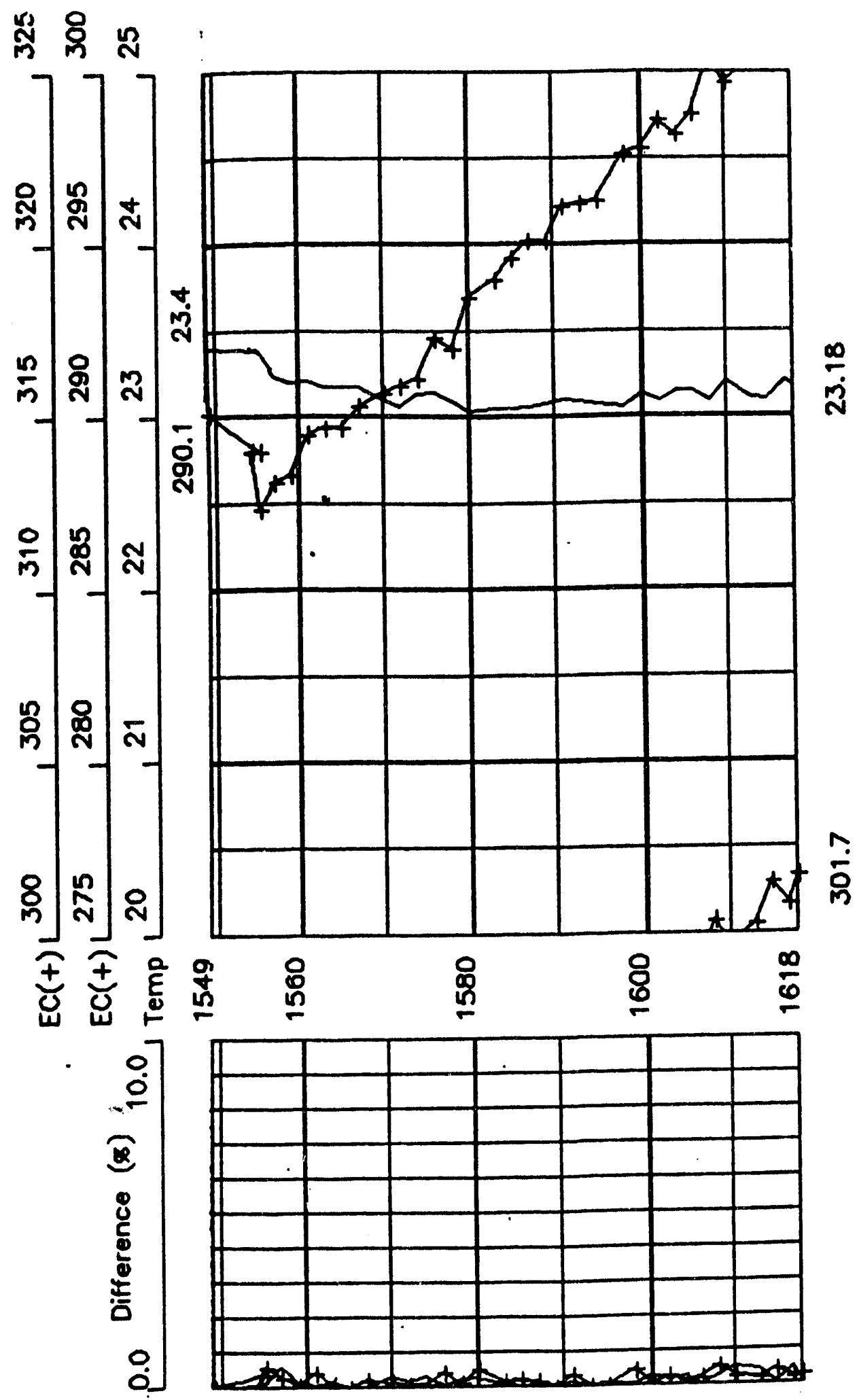


-- Temperature and EC Log --

Desert Research Institute

Temperature and EC Log Data

Well Name

:UE-1q

Location

Log Date

Operator

Tool

:Areo 1 NTS

:30 APR 92

:B.F. Lyles

Cal Date

:T1

Casing Diameter

Casing Stick-up

:30 APR 92

$: 13.4$ in

$: 5.0 \mathrm{ft}$

Depth Measurement Datum:Land Surface

TD Drilled

:2410. ft

Hole Eottom

$: 2283 \mathrm{ft}$

Land Elevation ( $\mathrm{ft}$ )

$: 4081.6 \mathrm{ft}$

Depth to Water (ft)

$: 1553.3$

Logging Speed $(\mathrm{ft} / \mathrm{min})$ :10 downward

Ran colibration ot beginning of run and entered

new multiplier and offset to get $E C+/-10$ umhos.

Tried getting through bridge once at $100 \mathrm{ft} / \mathrm{min}$.

Altas found the same bridge 24 APR 92 at $2279 \mathrm{ft}$.

Therefore, no more fill has come in the past

6 days.

Input file name: ve $1 q \rightarrow 1$.dat

Logging time start 17:28 end 18:41

\begin{tabular}{lrrr} 
& \multicolumn{1}{c}{ Min } & \multicolumn{1}{c}{ Max } & Range \\
Depth(ft) & 1554.0 & 2283.0 & 729.0 \\
Temp (C) & 23.3 & 27.5 & 4.2
\end{tabular}




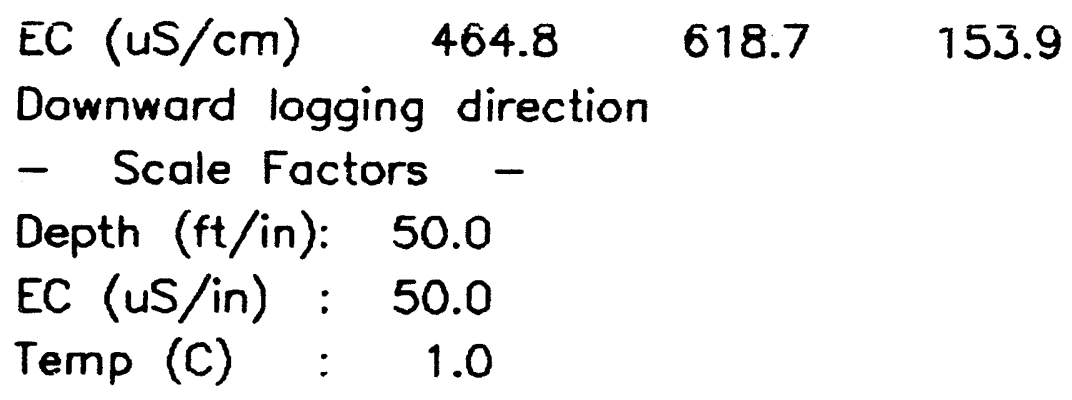




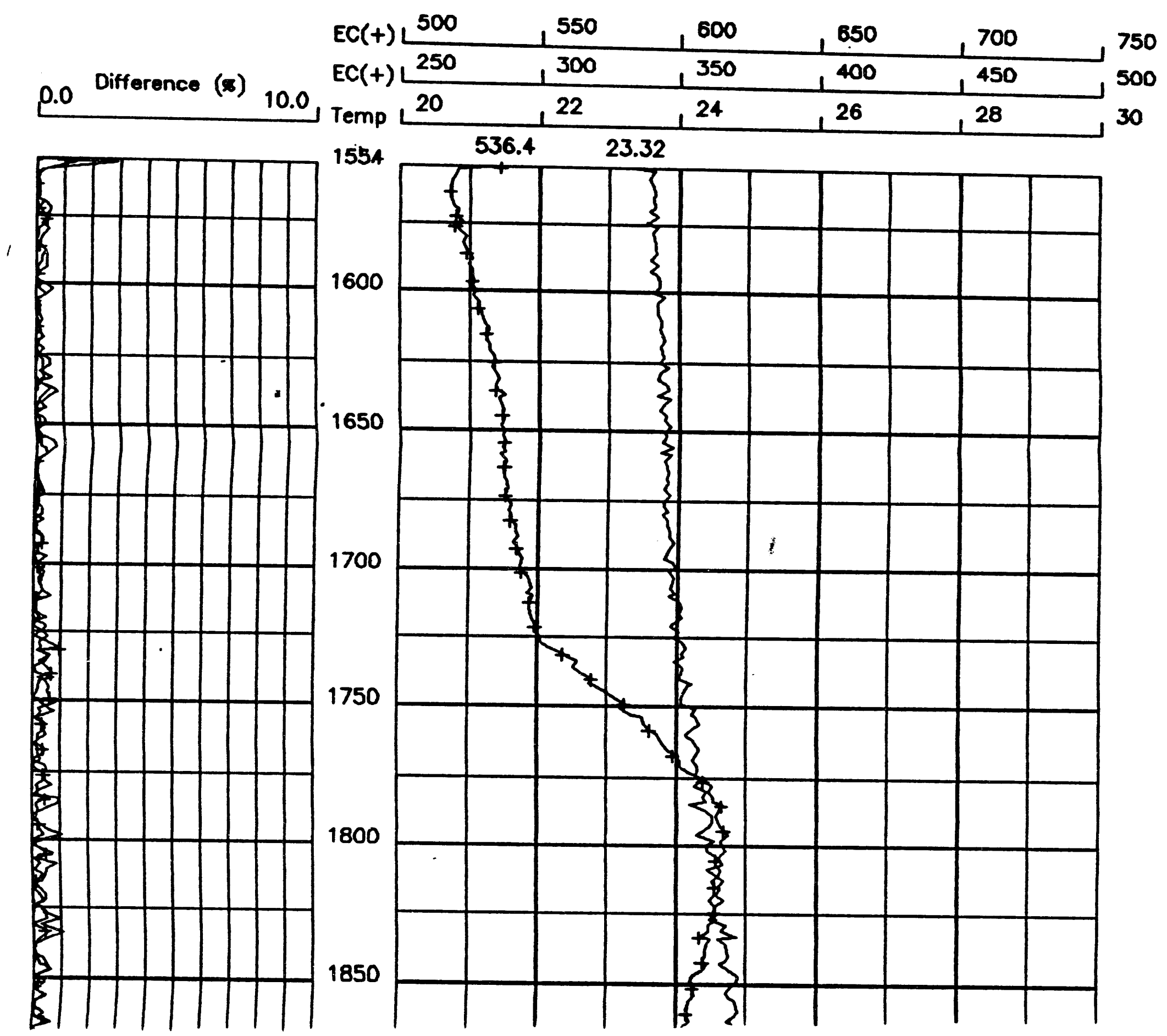




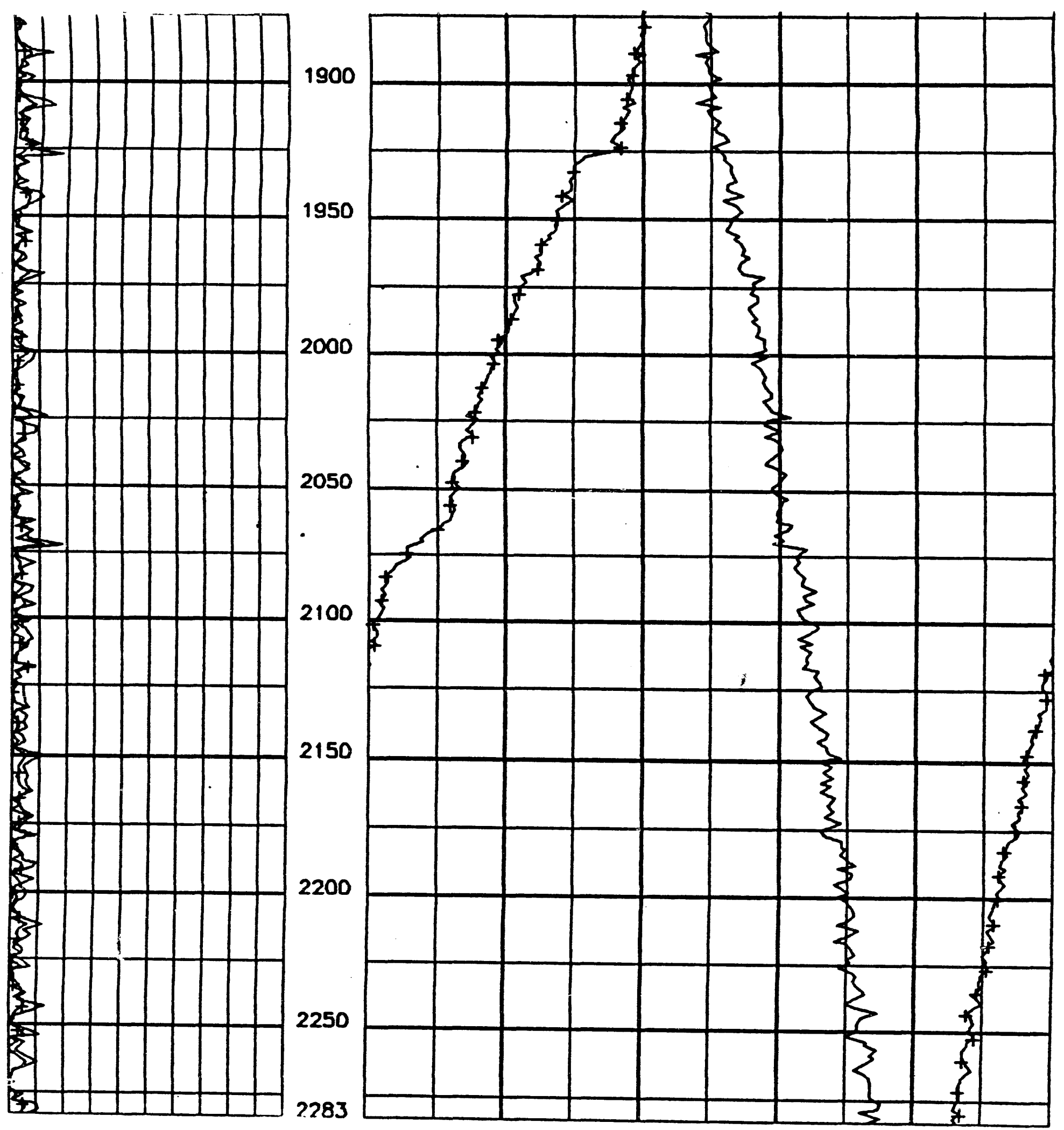




\section{-- Temperature and EC Log --}

- Desert Research Institute

Temperature and EC Log Dato

Well Nome

:USGS Test Well B Ex.

Location

:Areo 6 NTS

Log Date

Operator

:19 AUG 91

Tool

:B.F. Lyles; S. Hokett "

:T1

Cal Date

:19 AUG 91

Casing Diameter

$: 12$ inch

Casing Stick-up

$: 1.2 \mathrm{ft}$

Depth Measurement Datum:Land Surface

TD Drilled

$: 1675 \mathrm{ft}$

Hole Bottom

$: 1656.9 \mathrm{ft}$

Land Elevation ( $\mathrm{ft}$ ) $: 3929 \mathrm{ft}$

Depth to Water (ft)

$: 1503.8 \mathrm{ft}$

Logging Speed ( $\mathrm{ft} / \mathrm{min}$ )

$: 10$

Run No. 2 with $\pi 1$, found gunk in bottom of well - strong

hydrocarbon odor 
Input file name: twb2d.dat

Logging time start 18:28 end 18:41

$\begin{array}{cccc} & \text { Min } & \text { Max } & \text { Range } \\ \text { Depth(ft) } & 1504.0 & 1653.0 & 149.0\end{array}$

$\begin{array}{llll}\text { Ternp (C) } & 24.5 & 24.8 & 0.4\end{array}$

EC (uS/cm) $300.5 \quad 304.5 \quad 4.0$

Downward logging direction

- Scale Foctors -

Depth (ft/in): 20.0

EC (us/in) : 1.0

Temp (C) : 1.0 


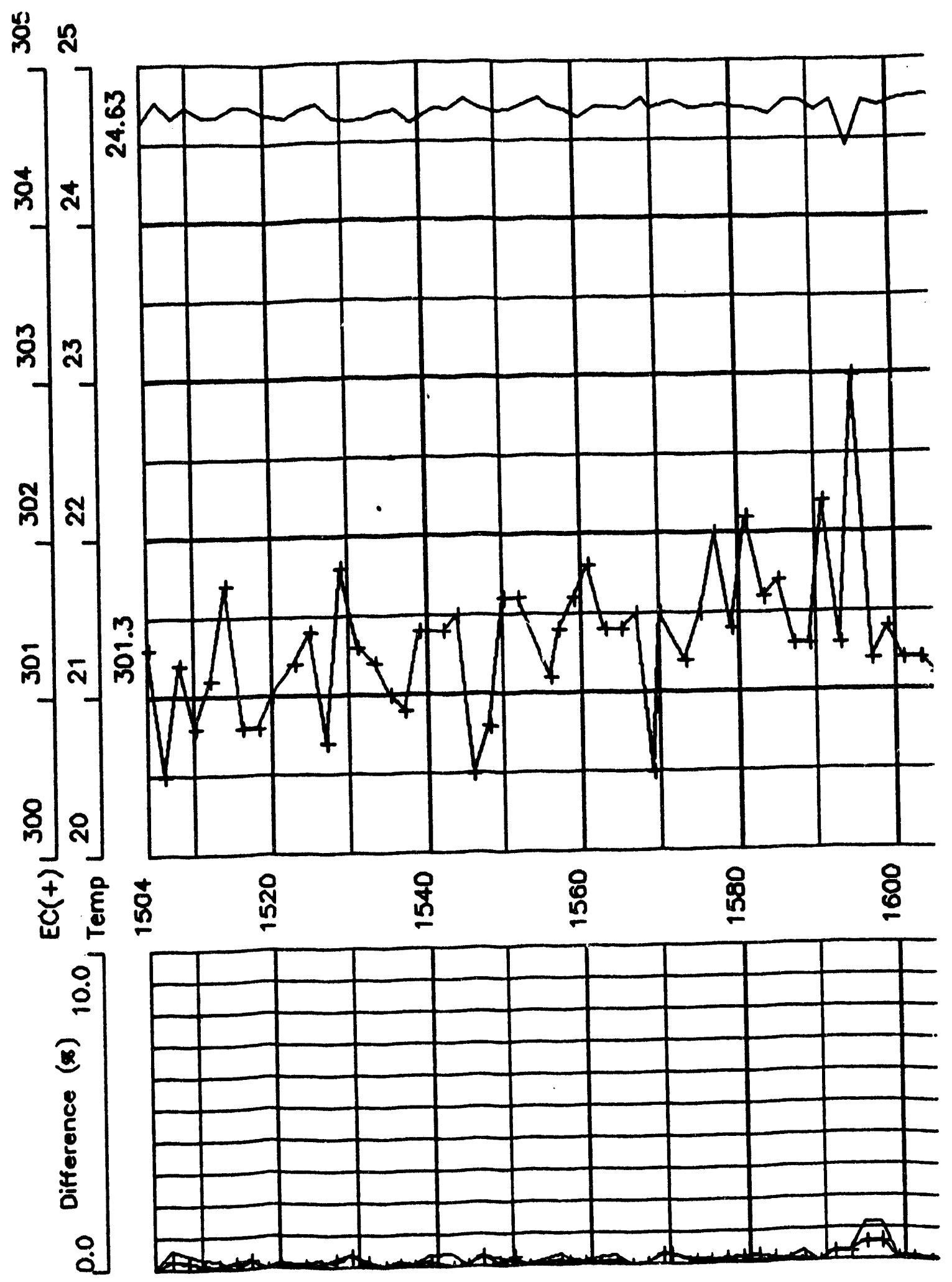




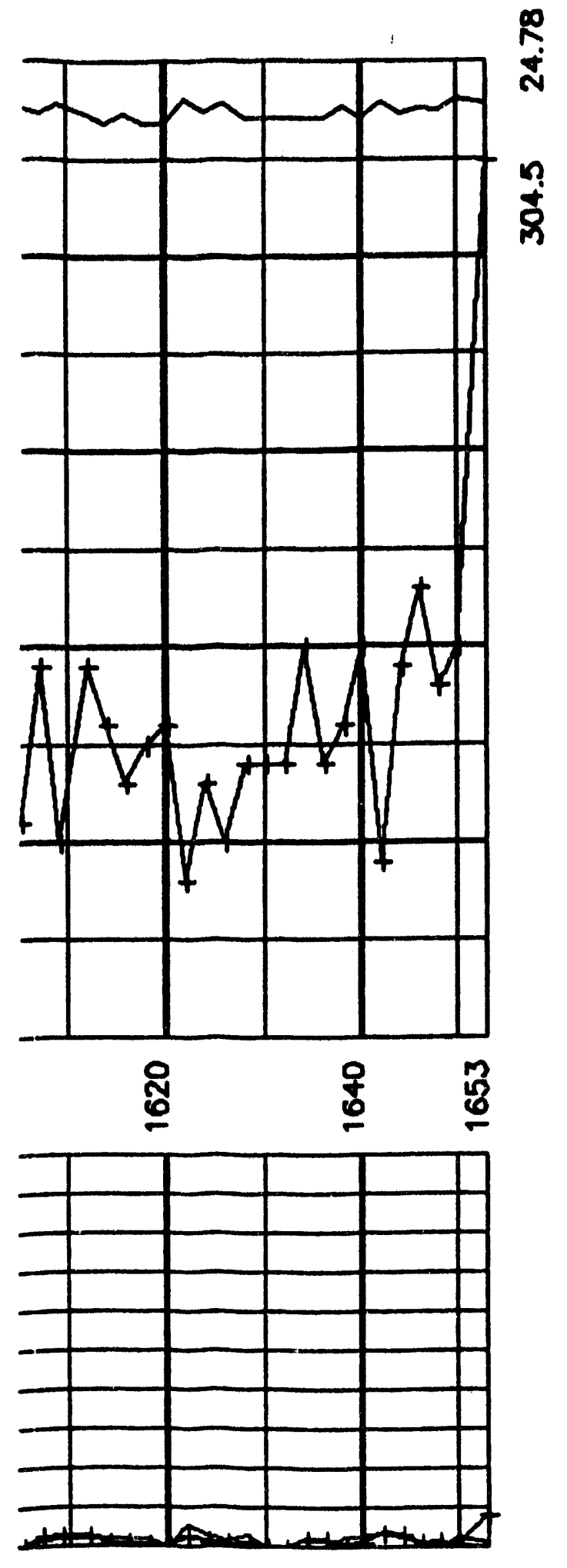




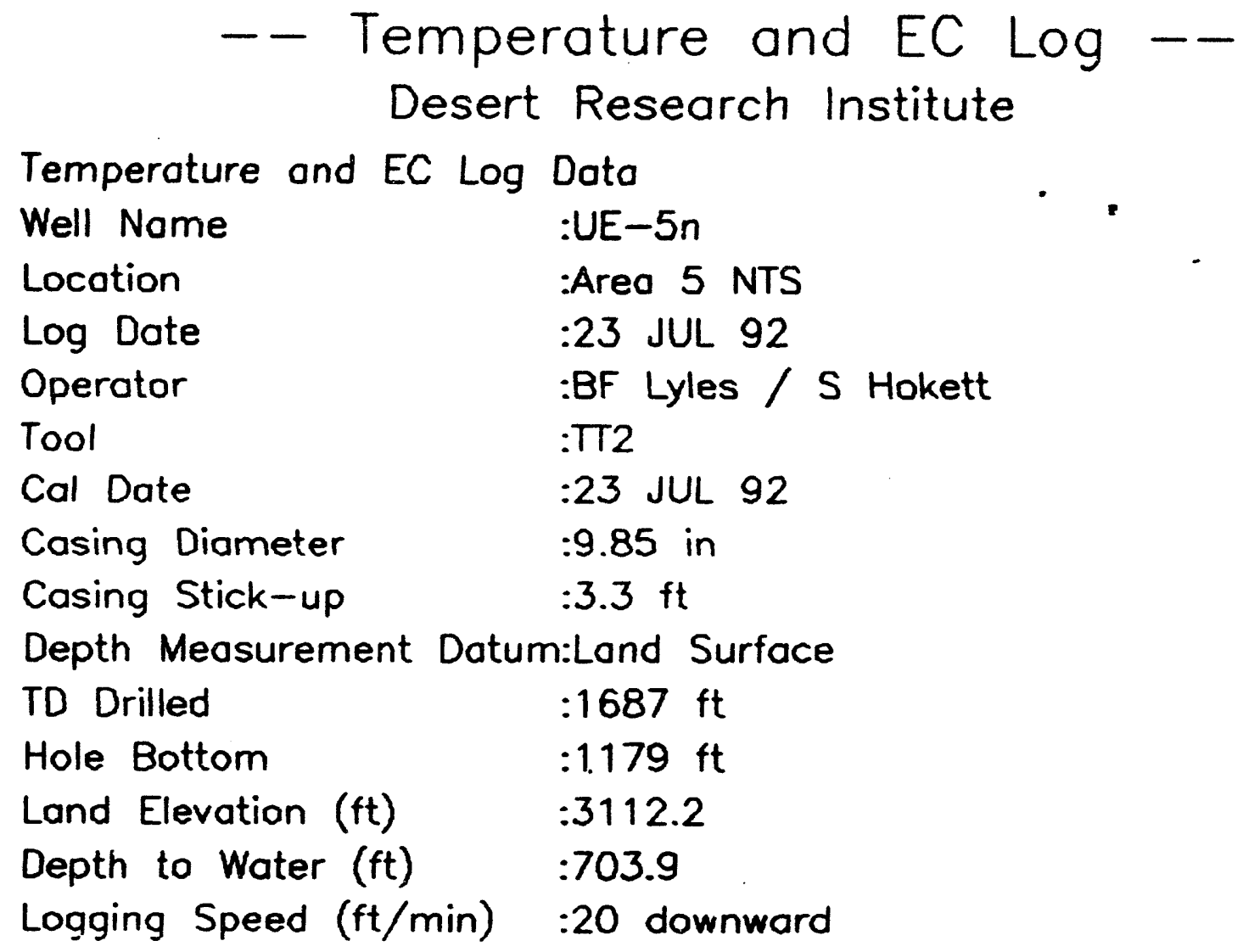


Run 2.

Found obstruction again at $1179 \mathrm{ft}$.

Input file name: ue $5 n \rightarrow 2 d$.dat

Logging time start $14: 33$ end $14: 52$

Min Max Range

Depth(it) $\quad 708.0 \quad 1185.0 \quad 477.0$

$\begin{array}{llll}\text { Temp (C) } & 21.9 & 24.1 & 2.2\end{array}$

$\begin{array}{llll}E C(u S / c m & 363.6 & 410.5 & 46.9\end{array}$

Downward logging direction

- Scale Factors -

Depth (ft/in): 50.0

EC (uS/in) : 20.0

Temp (C) : 1.0 


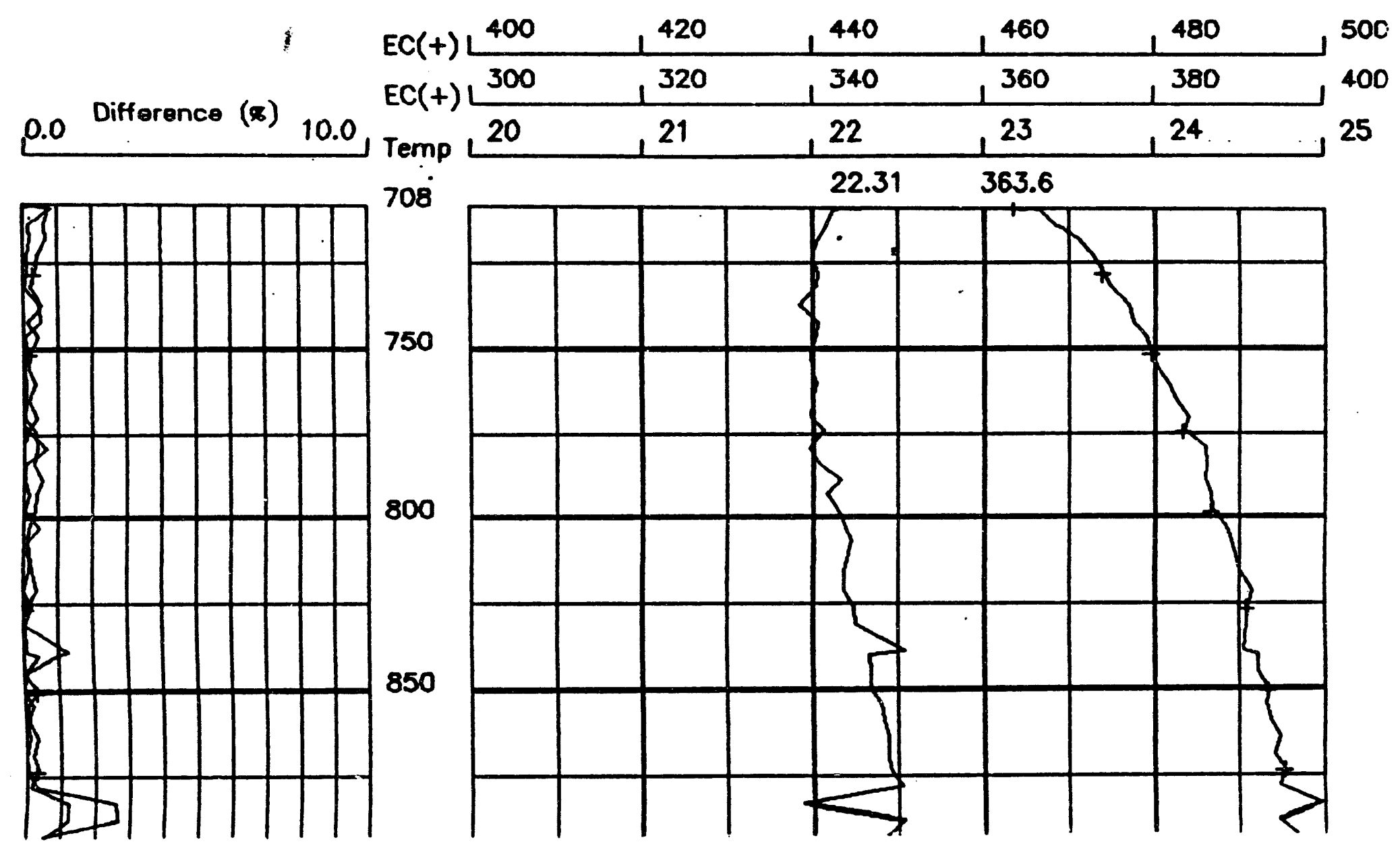




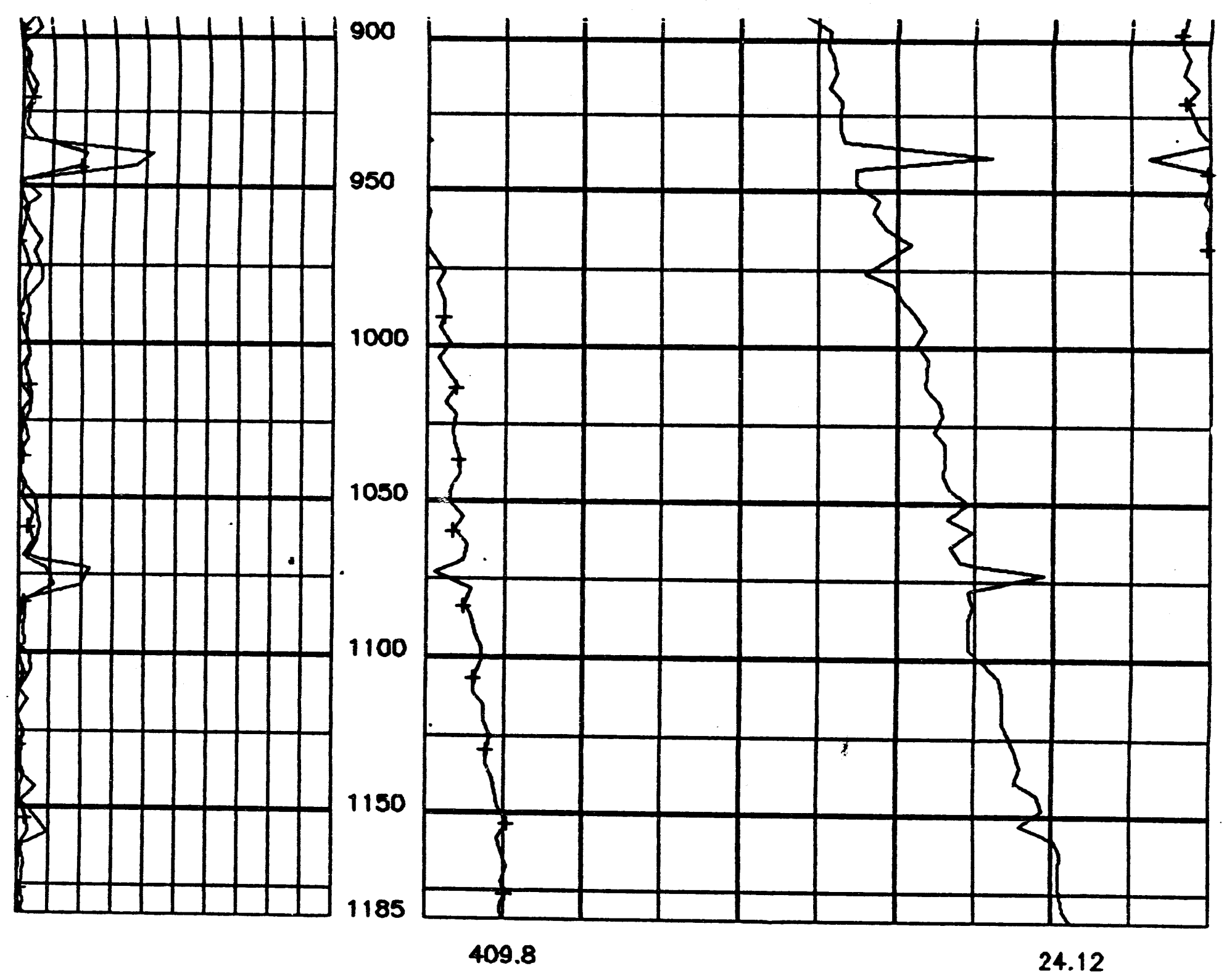




\section{DISTRIBUTION}

\section{U.S. Department of Energy}

Gylan Allen

Test Operations Division

Nevada Operations Office

U.S. Dept. of Energy

P.O. Box 98518

Las Vegas, NV 89193-8518

Doug Duncan

Hydrology Program Manager

Office of Environmental Restoration \& Waste

Management

Nevada Operations Office

U.S. Dept. of Energy

P.O. Box 98518

Las Vegas, NV 89193-8518

Don Elle, Director

Environment Protection Division

Nevada Operations Office

U.S. Dept. of Energy

P.O. Box 98518

Las Vegas, NV 89193-8518

Joseph N. Fiore, Acting Asst. Mgr.

Office of Environmental Restoration \& Waste

Management

Nevada Operations Office

U.S. Dept. of Energy

P.O. Box 98518

Las Vegas, NV 89193-8518

Joseph H. Kitchen

Technology and Program Management Division

Nevada Operations Office

U.S. Dept. of Energy

P.O. Box 98518

Las Vegas, NV 89193-8518

Steve Lawrence

Environmental Restoration Division

Nevada Operations Office

U.S. Dept. of Energy

P.O. Box 98518

Las Vegas, NV 89193-8518
John S. Ledbetter

Contracts Division

Nevada Operations Office

U.S. Dept. of Energy

P.O. Box 98518, MS 505

Las Vegas, NV 89193-8518

Steve Leedom

Test Operations Division

Nevada Operations Office

U.S. Dept. of Energy

P.O. Box 98518

Las Vegas, NV 89193-8518

Steve Mellington, Director

Environmental Restoration Division

Nevada Operations Office

U.S. Dept. of Energy

P.O. Box 98518

Las Vegas, NV 89193-8518

Technical Information Resource Center

Nevada Operations Office

U.S. Dept. of Energy

P.O. Box 98518

Las Vegas, NV 89193-8518

Richard Peart

Environmental Protection Division

Nevada Operations Office

U.S. Dept. of Energy

P.O. Box 98518

Las Vegas, NV 89193-8518

\section{U.S. Department of Defense}

David Bedsun

Defense Nuclear Agency

U.S. Department of Defense

P.O. Box 98539

Las Vegas, NV 89193-8539

Lawrence Livermore National Laboratory

Lee Davisson

Nuclear Chemistry Division

Lawrence Livermore National Laboratory

P.O. Box 808, MS L237

Livermore, CA 94550 
Greg Nimz

Lawrence Livermore National Laboratory

P.O. Box 808, MS L233

Livermore, CA 94550

Los Alamos National Laboratory

Joe Thompson

Los Alamos National Laboratory

INC-11, MS J514

P.O. Box 1663

Los Alamos, NM 87545

\section{U.S. Geological Survey}

Virginia Glanzman

U.S. Geological Survey

Box 2506, MS 913

Denver Federal Center

Denver, CO 80225

Randy Laczniak

U.S. Geological Survey

Water Resources Division

6770 S. Paradise Rd.

Las Vegas, NV 89119

Paul Orkild

U.S. Geological Survey

Box 2506, MS 913

Denver Federal Center

Denver, CO 80225

Doug Trudeau

U.S. Geological Survey

Water Resources Division

6770 S. Paradise Rd.

Las Vegas, NV 89119

Desert Research Institute

David Gillespie

Desert Research Institute

Water Resources Center

P.O. Box 19040

Las Vegas, NV 89132-0040
Roger Jacobson

Desert Research Institute

Water Resources Center

P.O. Box 19040

Las Vegas, NV 89132-0040

Marjory Jones

Desert Research Institute

Water Resources Center

P.O. Box 60220

Reno, NV 89506-0220

Brad Lyles

Desert Research Institute

Water Resources Center

P.O. Box 19040

Las Vegas, NV 89132-0040

Chuck Russell

Desert Research Institute

Water Resources Center

P.O. Box 19040

Las Vegas, NV 89132-0040

Ratheon Services Nevada

George Juniel

Ratheon Services Nevada

P.O. Box 328

Mercury, NV 89023

Reynolds Electrical \& Engineering Co.

Martha DeMarre

Chief, Document Research Section

Health Protection Dept.

Reynolds Electrical \& Engineering Co.

P.O. Box 98521

Las Vegas, NV 89193-8521

Brian Dozier

Reynolds Electrical \& Engineering Co.

2501 Wyandotte

Mercury, NV 89102

\section{LIBRARIES}

Archives

Getchell Library

University of Nevada, Reno

Beverly Carter

MacKay School of Mines Library

University of Nevada, Reno 
Stead Library

Desert Research Institute

Reno, Nevada

Southem Nevada Science Center

Water Resources Center, Library

P.O. Box 19040

Las Vegas, NV 89132-0040

Document Section, Library

University of Nevada, Las Vegas

4505 Maryland Parkway

Las Vegas, NV 89154

Annie Kelley

State Documents Department

Nevada State Library

Capitol Complex

Carson City, NV 89710

Water Resources Research Archives

University of Califormia

Room 40, North Gate Hall

Berkeley, CA 94720

International Technology Corp.

Debbie Cave

Geotrans

4888 Pearl East Circle

Suite $300 \mathrm{E}$

Boulder, CO 80301

John Eberlin

International Technology Corp.

4330 Valley View

Suite 114

MS-439

Las Vegas, NV 89103

ATTN: Susy Hammermeister

Bill Fryer

Intemational Technology Corp.

4330 Valley View

Suite 114

Las Vegas, NV 89103
Mike O'Hagen

International Technology Corp.

4330 Valley View

Suite 114

Las Vegas, NV 89103

Ed Price

International Technology Corp.

4330 Valley View

Suite 114

Las Vegas, NV 89103

K.C. Thompson

International Technology Corp. c/o Nevada Operations Office

U.S. Dept. of Energy

P.O. Box 98518

Las Vegas, NV 89193-8518

Rick Waddell

Geotrans

c/o IT

4330 Valley View

Suite 112

MS-439

Las Vegas, NV 89103

Dan Waterson

International Technology Corp.

4330 Valley View

Suite 114

Las Vegas, NV 89103

Joe Yeasted

International Technology Corp.

4330 Valley View

Suite 112

MS-439

Las Vegas, NV 89103

John Zysloss

Intemational Technology Corp.

4330 Valley View

Suite 114

Las Vegas, NV 89103 
$r$
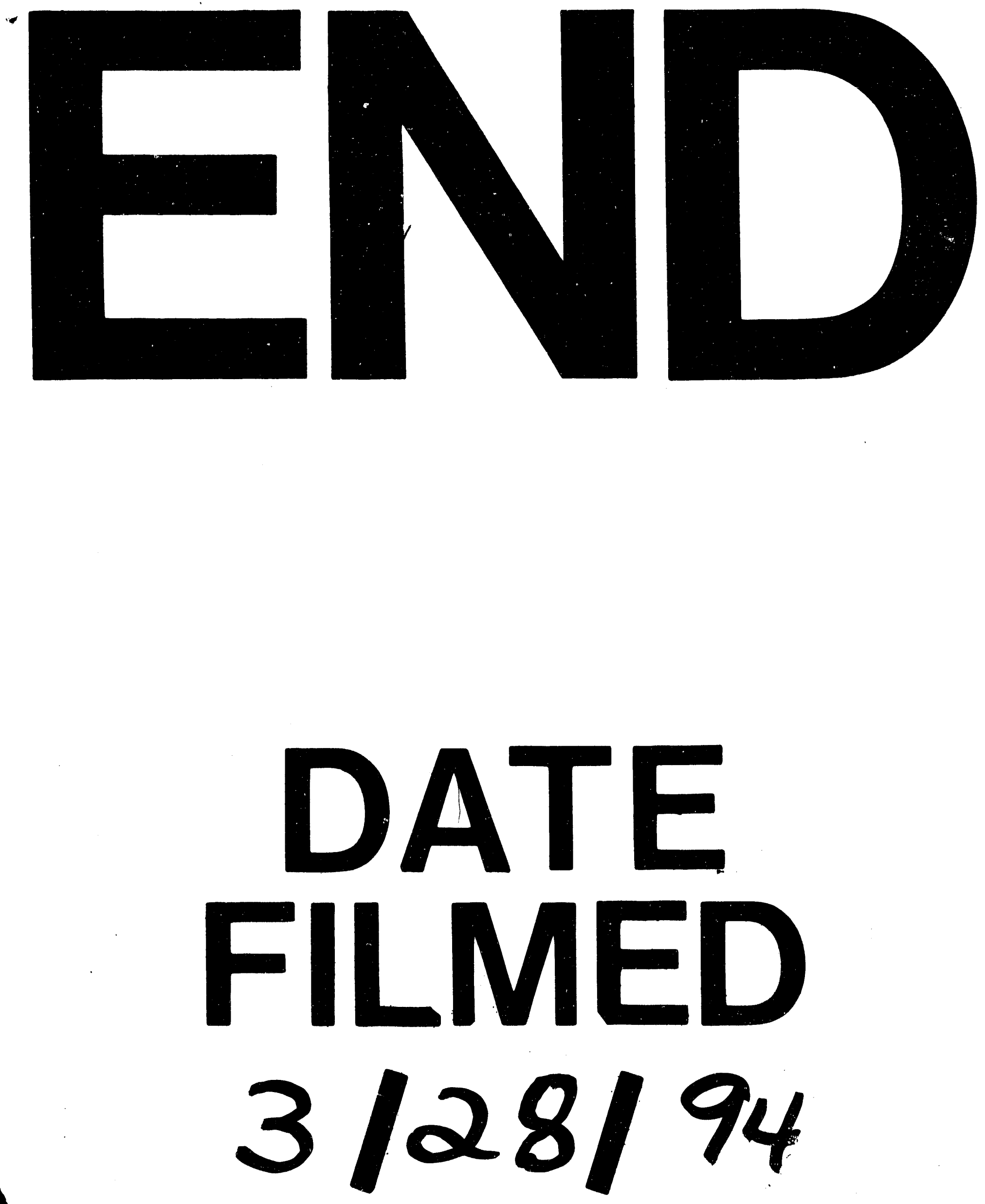

I 
